PNL-6610

UC-95d

$18 \mathrm{~J}$

\title{
Prototype Dining Hall Energy Efficiency Study
}

R. P. Mazzucchi

S. A. Bailey

P. W. Zimmerman

June 1988

Prepared for the

Housing and Services Directorate

U.S. Air Force Engineering and Service Center

Tyndall Air Force Base, Florida under a Related Services Agreement

with the U.S. Department of Energy

under Contract DE-AC06-76RLO 1830

Pacific Northwest Laboratory

Operated for the U.S. Department of Energy

by Battelle Memorial Institute 


\section{DISCLAIMER}

This report was prepared as an account of work sponsored by an agency of the United States Government. Neither the United States Government nor any agency thereof, nor Battelle Memorial Institute, nor any or their employees, makes any warranty, expressed or implied, or assumes any legal liability or responsibility for the accuracy, completeness, or usefulness of any information, apparatus, produc, or process disclosed, or represents that its use would not infringe privately owned rights. Reference herein to any specific commercial product, process, or service by trade name, trademark, manufacturer, or otherwise doe:s not necessarily constitute or imply its endorsement, recommendation, or favoring by the United States Government or any agency thereof, or Battelle Memorial Institute. The views and opinions of authors expressed herein do not necessarily state or reflect those of the United States Government or any agency thereof, or Battelle Memorial Institute.

\section{PACIFIC NORTHWEST LABORAIORY operated by \\ BATTELLE MEMORIAL INSTITLTTE for the \\ UNITED STATES DEPARTMENT OF ENERGY under Contract DE-ACO6-76RLO 1830}

Printed in the United States of America
Available from
National rechnical Information Service
United States Department of Commerce
5285 Port Royal Road
Springfield, Virginia 22161
NTIS Price Codes
Micrafiche A01
Printed Copy
Pages
C01-025
$026-050$


PROTOTYPE DINING HALL ENERGY EFFICIENCY STUDY

\author{
R. P. Mazzucchi \\ S. A. Bailey \\ P. H. Zimmerman
}

June 1988

Prepared for the Housing and Services Directorate U.S. Air Force Engineering and Service Center Tyndall Air Force Base, Florida under a Related Services Agreement with the U.S. Department of Energy

Contract DE-AC06-76RLO 1830

Pacific Northwest Laboratory Richland, Washington 99352 



\section{SUMMARY}

The energy consumption of food service facilities is among the highest of any commercial building type, owing to the special requirements for food preparation, sanitation, and ventilation. Consequently, the U.S. Air Force Engineering and Services Center contracted with Pacific Northwest Laboratory to collect and analyze end-use energy consumption data for a prototypical dining hall and make specific recommendations on cost-effective energy conservation options. This information will be used to establish or update criteria for dining hall designs and retrofits as appropriate.

The study involved the following discrete steps:

1. A dining hall was selected to serve as a prototype for this study, based upon its typicality and ease of measurement.

2. A measurement plan was developed to sub-meter major energy end-uses, interior temperatures, and climate factors.

3. Sensors and data logging equipinent were installed and calibrated.

4. Data quality was verified, and hourly interval data were collected for a 1-year period.

5. Characteristics data were compiled to initialize an energy use simulation model.

6. A simulation model was calibrated, making use of the energy consumption measurements .

7. A climate analysis was conducted to cluster 46 U.S. weather stations into four climate types for the simplified analys is method.

8. A list of energy conservation opportunities was developed and specified for new or retrofit construction based on the prototype.

9. The simulation model was used to estimate the energy savings associated with each measure in each climate type. 
10. A simple procedure was developed to calculate the savings-to-investment ratios based upon locally derived fuel costs, escalation rates, and measure costs.

This analysis reveals that the prototype dining hall energy usage is similar to that of other full service restaurants that have been previously studied. The dining hall was estimated to consume approximately $480,000 \mathrm{Btu} / \mathrm{ft} 2 / \mathrm{yr}$ as compared to a range of 390,000 to 730,000 for the other restaurants studied. Between one-third and one-half of dining hall energy is used for heating, ventilation, and air conditioning, depending upon the severity of the climate and the interior conditions to be maintained. Approximately one-quarter of the energy consumed is for food preparation, and the remaining energy is for refrigeration, sanitation, and lighting.

Two types of energy conservation opportunities are described: load reduction measures, and system efficiency improvements. Because the energy savings and cost-effectiveness of these measures is largely affected by weather, a total of 46 different weather stations were used to develop four climate domains for a simplified analysis method. In each of these domains, 22 load reduction opportunities are assessed, as well as 8 system efficiency improvements.

Application of all the measures found to be cost effective for the prototype dining facility using average national fuel prices and escalation rates, would result in energy savings of from $20 \%$ to $35 \%$ of the base case energy use, depending upon the severity of the clinate. The total cost of these measures would range from $\$ 75,000$ to $\$ 125,000$ per facility.

In light of the dependency of the performance of energy conservation measures on climate, and the dependency of cost-effectiveness on local fue 1 prices, it is necessary to conduct conservation assessments using site specific information. For this reason, a set of worksheets have been prepared to guide a simplified analysis that is tailored to a particular climate type and set of OOE regional fuel prices. For even greater accuracy, the ASEAM 2.1 simulation model utilized for this study can be modified and run with 
local weather summaries. The report documents the development and calibration of this tool for the prototype dining hall to pave the way for future applications. 



\section{ACRONYMS}

AFESC

U.S. Air Force Engineering and Services Center

ASEAM 2.1

A Simplified Energy Analysis Method, Version 2.1

ASHRAE

American Society of Heating, Refrigerating, and Air Conditioning Engineers

ASTM American Socjety for Testing and Materials

COP coefficient of performance

DOE U.S. Department of Energy

EPRI Electric Power Research Institute

FC

fuel costs

FEMP

Federal Energy Management Program

H\&V

heating and ventilating unit

HVAC

heating, ventilation, and air conditioning

IES

Illuminating Engineering Society of North America

MBtu

million British thermal units

NPV

net-present-value

NRA

National Restaurant Association

PNL

Pacific Northwest Laboratory

SIR

savings-to-investment ratio

UPW

uniform present worth factors

USAF

U.S. Air Force

VAV

variable air volume 



\section{CONTENTS}

SUMMARY ......................

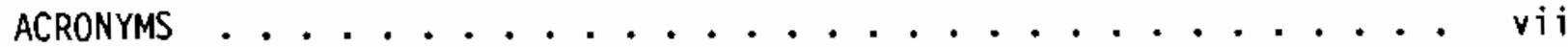

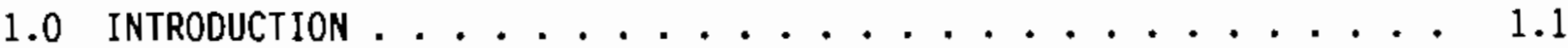

2.0 THE PROTOTYPE DINING HALL . . . . . . . . . . 2.1

2.1 HOURS OF OPERATION AND ACTIVITY LEVELS . . . . . . . 2.1

2.2 CONSTRUCTION FEATURES . . . . . . . . . . . 2.2

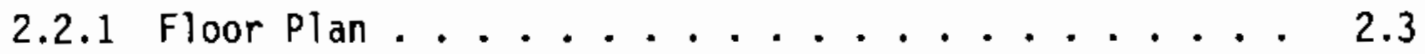

2.2 .2 Envelope Features ............ 2.3

2.2 .3 System Features . . . . . . . . . . 2.5

2.3 PROTOTYPE ENERGY CONSUMPTION MEASUREMENTS . . . . . . . 2.5

2.3.1 Measurement Plan ............. 2.5

2.3.2 Data Verification . . . . . . . . . . 2.6

2.3.3 Electrical Measurement Summary . . . . . . . . 2.7

3.0 PROTOTYPE SIMULATION MODEL AND ANALYSIS PROCESS $\ldots \ldots . \ldots$

3.1 THE ENERGY USE SIMULATION MODEL . . . . . . . . 3.1

3.2 COMPARISON OF THE PROTOTYPE DINING HALL

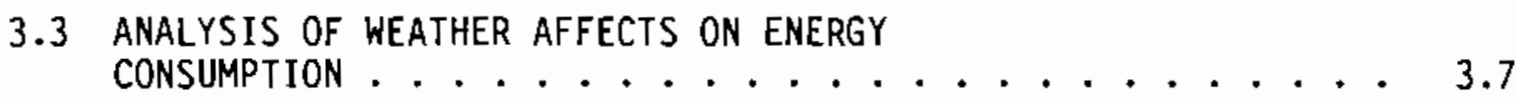

4.0 ENERGY CONSERVATION MEASURES FOR DINING HALLS . . . . . . . 4.1

4.1 FOOD PREPARATION .................... 4.1

4.2 SANITATION .......................... 4.3

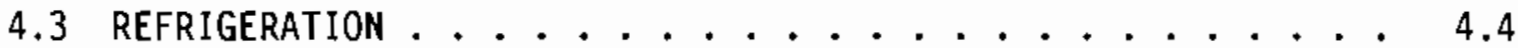

4.4 LIGHTING . . . . . . . . . . . . . 4.6 
4.5 HEATING, Ventilating, AND AiR CONDITIONING $\ldots \ldots \ldots$

5.0 ENERGY SAVINGS SENSITIVITY ANALYSIS . . . . . . . . . . 5.1

5.1 LOAD REDUCTION MEASURES . . . . . . . . . . . 5.1

5.1 .1 Window Treatments ................ 5.1

5.1 .2 Roof Insulation ................ 5.2

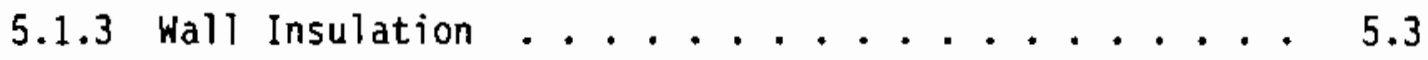

5.1.4 Lighting Efficiency Improvements........ 5.3

5.1.5 Refrigeration Efficiency Improvements ...... 5.3

5.1.6 Kitchen Equipment Efficiency Improvements . . . . 5.4

5.2 SYSTEM ENERGY EFFICIENCY IMPROVEMENTS . . . . . . . . 5.4

5.2 .1 Set-Back Themnostats ............ 5.5

5.2 .2 Hot Water Heat Pumps ........... 5.5

5.2.3 Kitchen Ventilation Reductions ........ 5.6

5.2 .4 Space Heating Heat Pumps . . . . . . . . 5.6

5.2.5 Variable Air Volume Heating and Cooling System . . . 5.6

5.2.6 Economizer Cycles . . . . . . . . . . 5.6

5.2.7 Improving the Air Conditioner COP . . . . . 5.7

5.3 THE IMPACT OF CLIMATE TYPES ON ENERGY SAVINGS . . . . . 5.7

6.0 A SIMPLE METHOD TO DETERMINE ENERGY CONSERVATION

MEASURE COST-EFFECTIVENESS .................... 6.1

6.1 SAMPLE APPLICATIONS OF THE SIMPLE ANALYSIS METHOD $\ldots \ldots .11$

7.0 CONCLUSIONS AND RECOMMENDATIONS $\ldots \ldots \ldots . \ldots . \ldots . \ldots$

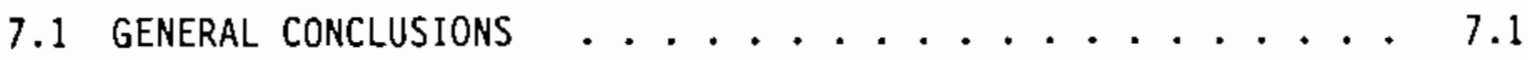

7.2 GeneRAL RECOMMENDATIONS $\ldots \ldots \ldots \ldots . \ldots . \ldots . \ldots . \ldots$

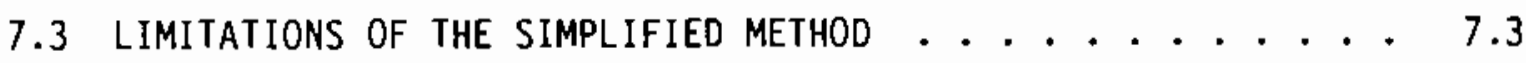


8.0 REFERENCES . . . . . . . . . . . . . . 8.0 APPENDIX A - ASEAM 2.1 MODELING AND CALIBRATION PROCESS . . . . . A.1 APPENDIX B - ASEAM INPUT SCREENS FOR BASE CASE . . . . . . . B. 1 



\section{FIGURES}

2.1 MONTHLY TOTAL MEAL COUNT $\ldots \ldots \ldots . \ldots \ldots$

2.2 DINING HALL FLOOR PLAN ......................... 2.4

2.3 ELECTRICAL END-USE SHARES FOR PROTOTYPE $\ldots \ldots \ldots \ldots \ldots \ldots . \ldots \ldots$
DINING HALL, $1986-1987 \ldots \ldots \ldots \ldots$

2.4 MONTHLY END-USE ElECTRICAL CONSUMPTION $\ldots \ldots \ldots$

2.5 ELECTRICITY CONSUMPTION BY INTERIOR LIGHTING

2.6 ELECTRICITY CONSUMPTION BY FOOD PREPARATION COMPONENTS,

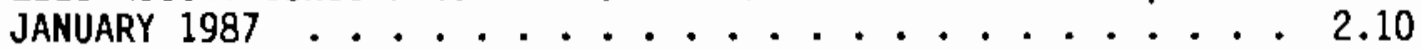

2.7 JANUARY AVERAGE DAY END-USE PROFILES . . . . . . . 2.11

2.8 JULY AVERAGE DAY END-USE PROFILES . . . . . . . . 2.11

3.1 ESTIMATEd ENERGY CONSUMPTION FOR STEAM PRODUCTION $\ldots \ldots .4$

3.2 EStimated total MONTHLY ENERG CONSUMption $\ldots \ldots . \ldots$

3.3 ESTIMATED ENERGY CONSUMPTION SHARES BY END USE $\ldots \ldots . . \ldots$

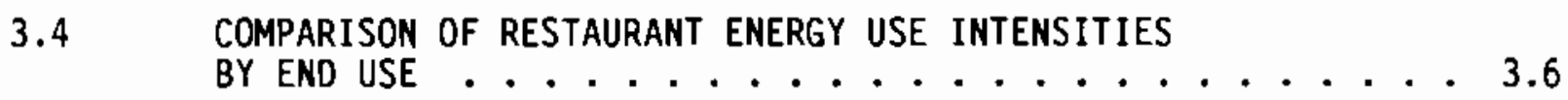

3.5 COMPARATIVE RESTAURANT ENERGY USE INTENSITIES

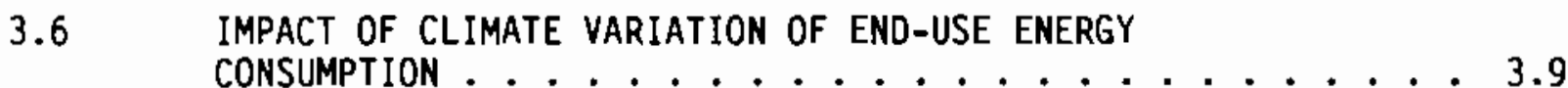

3.7 CLIMATE AREAS FOR THE SIMPLIFIED ANALYSIS METHOD . . . 3.10

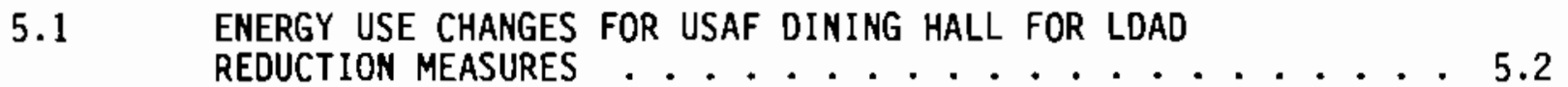

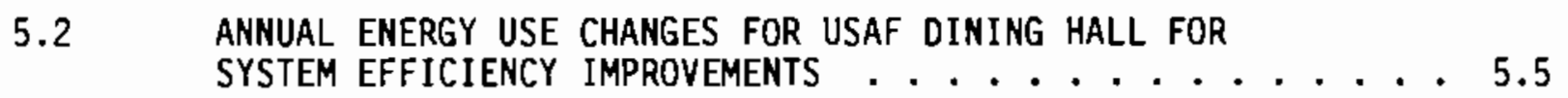

5.3 IMPACT OF LOAD REDUCTION MEASURES ON TOTAL ENERGY USE IN AN ALL-ELECTRIC BUILDING ......... 5.8

5.4 IMPACT OF SYSTEM EFFICIENCY IMPROVEMENT ON TOTAL ENERGY USE IN AN ALL-ELECTRIC BUILDING. . . . . . . 5.9 


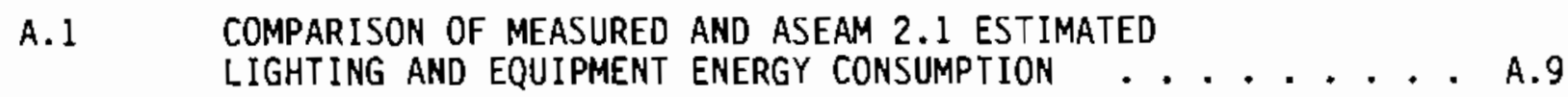

A.2 COMPARISON OF MEASURED AND ASEAM 2.1 ESTIMATED

FANS AND COOLING ENERGY ................ A.11 
TABLES

2.1 PATTERSON DINING HALL REGULAR HOURS OF OPERATION $\ldots \ldots$

2.2 PATTERSON DINING HALL EXERCISE AND ALERT HOURS

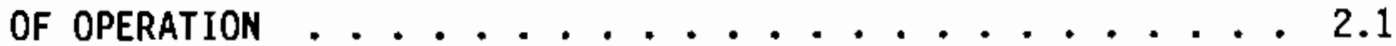

3.I COMPARISON OF USAF DINING HALL END-USE ENERGY

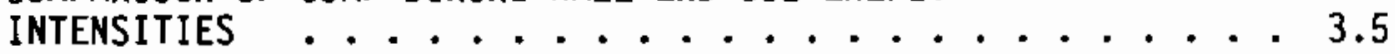

3.2 SUMMARY OF CONSUMPTION FOR 46 U.S. CITIES $\ldots \ldots \ldots . \ldots$

6.1 COLD CLIMATE SIMPLIFIED ANALYSIS WORKSHEET $\ldots \ldots . \ldots .6 . \ldots$

6.2 COOL CLIMATE SIMPLIFIED ANALYSIS WORKSHEET $\ldots \ldots . \ldots . . \ldots$

6.3 WARM CLIMATE SIMPLIFIED ANALYSIS WORKSHEET $\ldots \ldots . \ldots .7$

6.4 HOT CLIMATE SIMPLIFIEd ANALYSIS WORKSHEET . . . . . . . 6.9

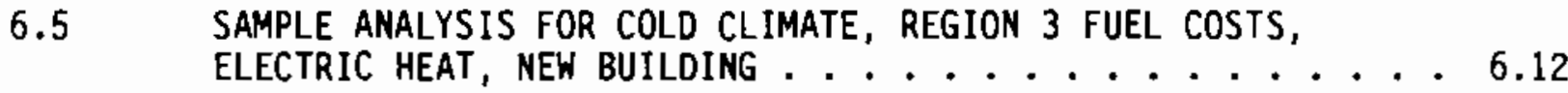

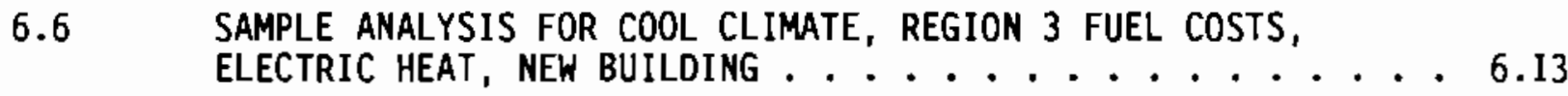

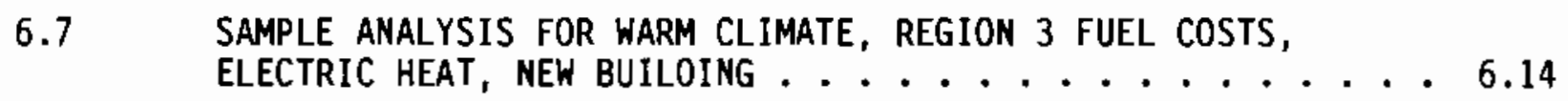

6.8 SAMPLE ANALYSIS FOR HOT CLIMATE, REGION 3 FUEL COSTS,

6.9 SAMPLE ANALYSIS FOR COLD CLIMATE, REgION 3 FUEL COSTS,
STEAM HEAT, NEW BUILDING . . 6.16

6.10 SAMPLE ANALYSIS FOR COOL CLIMATE, REgION 3 FUEL COSTS, STEAM HEAT, NEW BUILDING . . . . . . . . . . 6.17

6.11 SAMPLE ANALYSIS FOR WARM CLIMATE, REgION 3 FUEL COSTS, STEAM HEAT, NEW BUILDING ............ 6.18

6.12 SAMPLE ANALYSIS FOR HOT CLIMATE, REgION 3 FUEL COSTS, STEAM HEAT, NEW BUILDING ........................ 6.19

6.13 SUMMARY OF SAVINGS TO INVESTMENT RATIOS, REGION 3
FUEL COSTS, ELECTRIC HEAT, NEW BUILDING ....... $\ldots .2 \mathrm{\ldots}$

6.14 SUMMARY OF SAVINGS TO INVESTMENT RATIOS, REGION 3 FUEL COSTS, DISTRIC HEAT, NEW BUILDING . . . . . . 6.22 


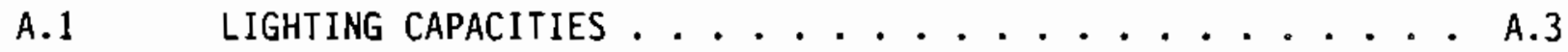

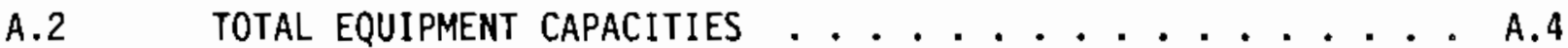

A.3 INDIVIDUAL EQUIPMENT CAPACITIES ......... A.5

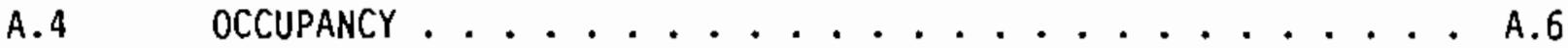

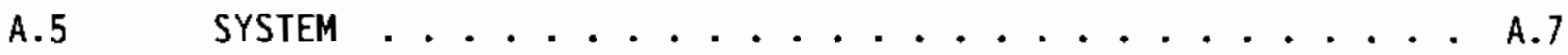




\subsection{INTRODUCTION}

The energy consumption of food service facilities is among the highest of any commercial building type, owing to the special requirements for food preparation, sanitation, and ventilation. Consequently, the U.S. Air Force Engineering and Services Center (AFESC) contracted with Pacific Northwest Laboratory (PNL)(a) to collect and analyze end-use energy consumption data for a prototypical dining hall and make specific recommendations on costeffective energy conservation options. This information will be used to establish or update criteria for dining hall designs and retrofits as appropriate.

The determination of cost-effective energy conservation measures for a specific facility is confounded by many considerations, including: 1) mission requirements (i.e., number of meals served and hours of operation) that vary from site to site, 2) the highly variable condition of existing facilities and equipment, 3) the dependence of mechanical equipment sizing upon the design conditions, 4) the impact of climate conditions and fuel sources on energy conservation measure effectiveness, 5) the significant variation of costs and escalation rates of energy from one region to another, and 6) the unknown and difficult to quantify and verify in situ performance of many conservation measures.

To provide useful and technically correct guidance to optimize building designs or retrofit projects, it is necessary to account for these conditions in the analysis or to make simplifying assumptions. Both approaches were used in this study. Simplifying assumptions were made by inferring that the characteristics data and non-heating, ventilation, and air conditioning (HVAC) energy use measurements at the prototype dining hall were representative of all dining halls. Sensitivity analyses were carried out to indicate the affects of climate on energy savings. Based upon these analyses, and on

(a) Operated by Battelle Memorial Institute for the U.S. Department of Energy under Contract DE-ACO6-76RLO 1830. 
reference information on fuel costs and escalation rates, a simple procedure to estimate the cost-effectiveness of generic energy conservation measures was developed.

Alternatively, the energy use model developed and calibrated by this study can be used to generate customized savings estimates and savings-toinvestment ratios for particular cases. The model operates on a personal computer and can easily be initialized with the base case file developed by this study. This file can then be modified as necessary to simulate the anticipated conditions at a particular site. Then the identified energy conservation opportunities can be simulated to generate savings estimates and savings-to-investment ratios which are appropriate for the particular case. For this reason an appendix is provided to detail the base case model inputs and the calibration process.

The report is organized into six sections and two appendixes. Section 2 describes the prototype dining hall selected for study and the measurement plan that was developed to submeter major energy end-uses, interior temperatures, and climate factors. The results of the end-use electrical consumption measurements are summarized and presented graphically.

Section 3 describes the ASEAM 2.1 (A Simplified Energy Analys is Method, Version 2.1) simulation model employed to estimate the steam heating requirements and the energy savings of selected conservation opportunities. The estimated energy use of the prototype dining hall is compared with seven other restaurants studied by the National Restaurant Association (NRA) as a reasonableness check. The prototype facility is modeled in each of 46 weather locations to indicate the sensitivity of heating, cooling, and total energy consumption to climate conditions and to develop climate domains for the simplified analysis method.

Sections 4 and 5 discuss the conservation measures applicable to the prototype dining hall, as well as other measures that should be considered when retrofitting an existing facility or building a new one. For each energy end use, the consumption estimates are reviewed and general guidance is offered regarding appropriate analysis methods and data sources for conservation 
as sessment.

Section 6 describes a simple method to determine energy conservation measure cost effectiveness. Forms have been developed for each of four climate types to summarize the energy savings analysis and to guide the costeffectiveness evaluation. An example is provided to detail the application of the simple method for a specific case study.

Section 7 provides a sumnary of conclusions and recommendations regarding cost-effective energy conservation measures. These findings are based upon the use of the simplified analysis method using average fuel prices and escalation rates to calculate savings-to-investment ratios for the full suite of conservation measures itemized. While the findings are not definitive, they do provide a valuable indication of the measures which are very costeffective or sensitive to climatic affects.

Two technical appendices have been prepared. Appendix A describes the ASEAM modelling and calibration process. The ASEAM base case model inputs are provided in Appendix $B$. 



\subsection{THE PROTOTYPE DINING HALL}

This section provides a brief description of the prototype dining hall characteristics and energy data. More detailed information is provided in the technical appendixes. These data were developed from the Patterson Dining Hall at the Dover Air Force Base in Delaware. This facility was selected by the AFESC to be typical of mid-1950 construction practice.

\subsection{HOURS OF OPERATION AND ACTIVITY LEVELS}

The dining hall serves breakfast, lunch, dinner, and a late night (midnight) meal. Two serving lines are operated according to the schedule identified in Table 2.1. During reserve officer training encampments in the summer, a second serving line is operated from 0630 to 0745 hours. During exercises and alerts, the schedule is altered to that shown in Table 2.2.

Table 2.1. Patterson Dining Hall Regular Hours of Operation Daily Serving Hours - Workdays

\begin{tabular}{lcc}
\multicolumn{1}{c}{ Meal } & Serving Hours & Serving Lines \\
\cline { 2 - 3 } Breakfast & $0600-0830$ & 1 \\
Lunch & $1100-1300$ & 2 \\
Dinner & $1600-1900$ & 2 \\
Late & $2245-0045$ & 1 \\
Daily Serving Hours - Weekends and Holidays \\
Meal & Serving Hours & Serving Lines \\
Brunch & $0600-1300$ & 1 \\
Dinner & $1530-1800$ & 2 \\
Late & $2245-0045$ & 1
\end{tabular}

Table 2.2. Patterson Dining Hall Exercise and Alert Hours of Operation

\begin{tabular}{lll}
\multicolumn{1}{c}{ Meal } & East Line & West Line \\
Breakfast & $0400-0830$ & \\
Lunch & $0930-1330$ & $0530-0930$ \\
Dinner & $1430-1930$ & $1030-1430$ \\
Late & $2030-0300$ & $1530-2030$ \\
Late & & $2130-0400$
\end{tabular}


Figure 2.1 depicts the number of meals served during each month of the monitoring period. The highest frequency of food service occurred in August 1986 with a total of 58,357 meals, or approximately 1880 meals per day. The lowest food service frequency was in December 1986 with a total of 43,675 meals, or approximately 1400 meals per day. The annual average number of meals per month and day is 50,174 and 1650 , respectively. Thus, monthly meal counts vary by as much as $15 \%$ from the average.

The facility manager indicated that peak food preparation activities typically occur from 0600 to 1030 hours and 1230 to 1530 hours daily. Cleanup activities are concentrated during the periods 0830 to 1030,1300 to 1430 , and 1900 to 2030 hours. Peak baking hours are from 2200 to 0630 daily.

\subsection{CONSTRUCTION FEATURES}

This section briefly describes the building floor plan, elevations, and mechanical equipment. More detailed information used to develop and calibrate the simulation model is provided in Appendix A.

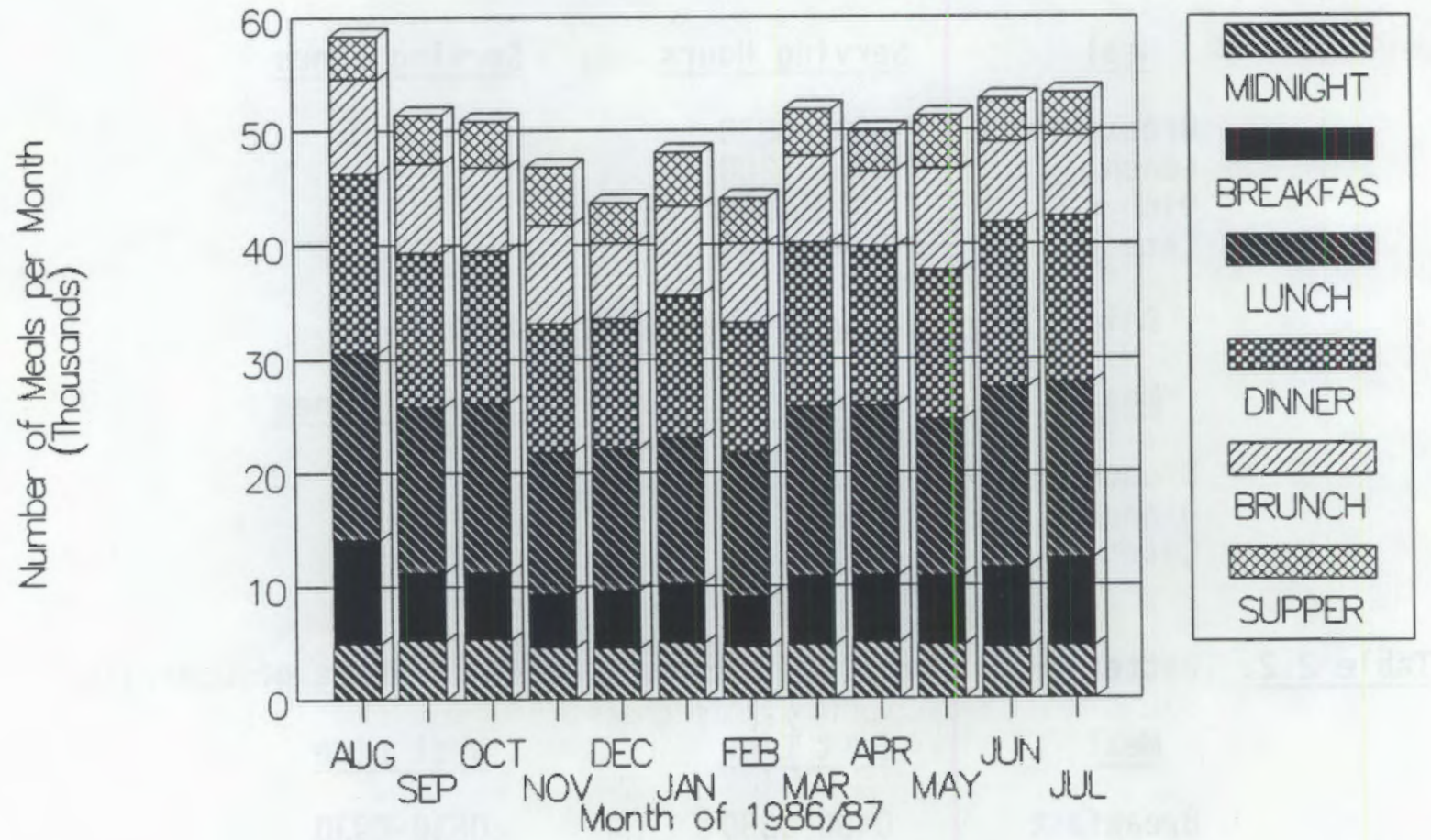

FIGURE 2.1. Monthly Total Meal Count 


\subsubsection{Floor Plan}

The dining hall floor plan is depicted in Figure 2.2. There are two dining areas of approximately $4000 \mathrm{ft} 2$ each. The east dining area includes a snack line, while the west dining area is used principally for meal service. Entry to these areas is through vestibules facing the east and west. Two small bathrooms are located at the front of the building for customer use.

The two dining areas are separated by a $840-\mathrm{ft} 2$ dishwashing area. A Hobart CPW117 dishmachine is enclosed, as well as a conveyor to move dishes from the scrapping area.

The kitchen lies to the north of these three areas and is approximately $2650 \mathrm{ft} 2$. Four lines of food preparation equipment are placed underneath exhaust hoods in the center. The west wall includes separate rooms for vegetable preparation, pot washing, and baking.

Dry good and refrigerated storage areas, as well as a small office, lie to the east of the kitchen. These areas total approximately $1350 \mathrm{ft} 2$.

The northeast section of the building provides employee bathrooms and locker rooms. The northwest section includes an office for contractor use. A covered loading dock is located between these areas. To the west of the office area, an unconditioned mechanical room houses the electrical switchgear, heat exchangers, and associated mechanical equipment.

\subsubsection{Envelope Features}

The walls are constructed of 8-in. concrete masonry units and 4-in. face brick. These layers are divided by a 2-in. air space. Figure 2.2 indicates the location of $8-\mathrm{ft}$-high windows with a $1-\mathrm{ft}$-high section at the base, which can be opened. The total glass area is $827 \mathrm{ft} 2$, or $12 \%$ of the total wall area. In addition to the two vestibule entries, there are glass emergency exit doors at the rear of the east and west dining areas, and two sets of metal doors leading to the loading dock.

The roof is of built-up construction over a 1-1/2-in. metal deck. This deck is supported by steel joists. Acoustical tile is suspended approximately 


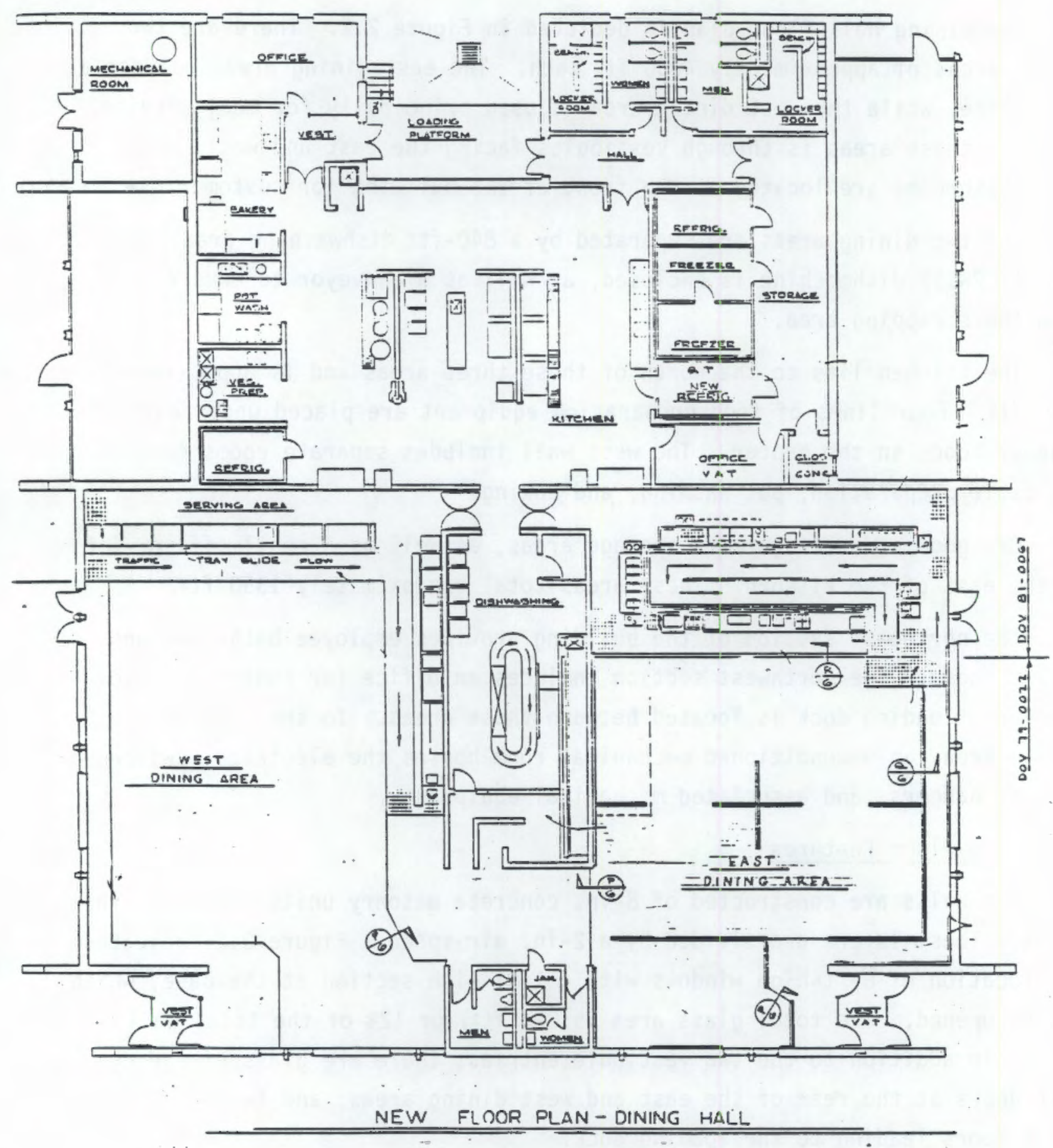

FIGURE 2.2. Dining Hall Floor Plan 
3-ft below the roof. Ducting for the heating and cooling systems is located in this space.

The foundation is a 4-in. concrete slab poured over a vapor barrier. One inch of rigid insulation is installed around the perimeter to a depth of $2-\mathrm{ft}$.

\subsubsection{System Features}

The dining hall is served by four HVAC systems: two large vapor compression air conditioners, one large heating and ventilating unit serving the kitchen, and several hot water heating coils and convectors for the vestibules, bathrooms, and storage areas. Heating is provided by a hot water loop that is energized by a steam-to-hot water heat exchanger. This steam is provided by a coal-fired central heating plant serving the entire base.

The interior lighting is fluorescent with the exception of the east dining area, which has decorative incandescent fixtures. Exterior lighting is both incandescent and mercury vapor.

Food preparation and refrigeration equipment is located in the two serving lines and in the kitchen. Details regarding the type and capacities of this equipment are provided in Appendix A.

\subsection{PROTOTYPE ENERGY CONSUMPTION MEASUREMENTS}

The prototype dining hall was instrumented during the period from August 1986 through July 1987 to determine end-use energy consumption levels. Hourly interval data for over 100 sensors were collected and verified, to calibrate the simulation model and to provide valuable insights of daily energy consumption profiles. This section briefly describes the measurement plan and summarizes the measurements.

\subsubsection{Measurement Plan}

Three 56-channel data loggers were installed. Two loggers, designated A and $B$, were devoted to the submetering of electrical consumption. The third logger collected temperature data to measure the HVAC system performance and interior comfort levels. Current transformers were placed around individual electric circuits and connected to electronic wattmeters. These wattmeters accumulated true power consumed for each phase of electrical service on an 
hourly basis. These values were stored in the logger memory and communicated to PNL on a weekly basis over telephone lines.

In Logger A, all three phases of the building total mains were monitored, as well as all three phases of the electrical panel mains, each air conditioning unit, hot water circulation pumps, indoor lighting, small food preparation devices, disposals, the pot washer, food storage in the snack line, steam kettles, and exhaust fans. The interior temperature of the cashier's office and the kitchen are also monitored by Logger A.

Logger B monitored all three phases of the panel mains, as well as all three phases of the exhaust fans, refrigeration units, receptacles, steam equipment, fryers, grills, the heat and vent unit, ovens, food storage, dishmachine, snack line, and griddles.

Logger $C$ measured the temperature of the hot water supplied to and returned from each piece of terminal equipment. This includes the air conditioning units, the heating ventilating unit, unit heaters, and the vestibule convectors. The temperature of the air supplied to and from these terminal devices was also monitored, as well as the space temperatures in the office, kitchen, and dining areas. Finally, the exterior temperature and global horizontal solar flux was monitored. All these data were collected as hourly averages for periods during the heating and cooling seasons.

\subsubsection{Data Verification}

The data verification plan was designed to evaluate the accuracy of the installation and metered data. The data were examined in two manners: visual and energy use sum-check. These examinations used both 15-min interval and hourly interval data.

In the initial step, the first 5 days of data were subjected to a detailed visual inspection. This inspection identified obvious installation and documentation errors such as reversed current transformers or improper scaling factors.

The second step subjected the data to an energy balance using the First Law of thermodynamics. The balance requires that the electrical energy 
entering each service panel be equal to the electrical energy delivered to each of the circuits or devices served from the panel. This procedure verified that all the active circuits in the building were monitored correctly by the data acquisition system.

The verification process was completed three times randomly throughout the monitoring period. The initial verification found no installation errors. The second verification found an operational amplifier failure on one channel of Logger $B$ that was subsequently repaired. The third verification revealed several building modifications that continued through the end of the project.

After the initial verification, several Lotus 1-2-3(a) templates were developed to summarize and display the measurements. Each month, spreadsheets were examined to ensure data quality. The next section describes and summarizes these spreadsheets.

\subsubsection{Electrical Measurement Summary}

Display and discussion of all the end-use energy consumption measurements would entail the preparation of thousands of pages of graphics and text. This section endeavors to provide useful summaries of the data and display selected windows of the hourly measurements. However, all the available hourly consumption data were used to develop inputs for the simulation model employed to estimate energy savings potentials.

The end-use shares of electricity are depicted in Figure 2.3. The total is disaggregated into the following end uses: 1) interior lighting, 2) freezers and refrigeration equipment, 3) food preparation equipment, 4) sanitation (dishmachines and garbage disposals), 5) HVAC equipment, and 6) baking equipment. As indicated in Figure 2.3., one-third of the electrical use is for HVAC equipment, even though space and water heating energy is provided by district steam. Food preparation and baking comprise another one-third of the electrical use, and lighting, refrigeration, and sanitation constitute the remaining one-third.

(a) Lotus 1-2-3 is a registered trademark of the Lotus Development Corporation, 55 Cambridge Parkway, Cambridge, MA 02142. 


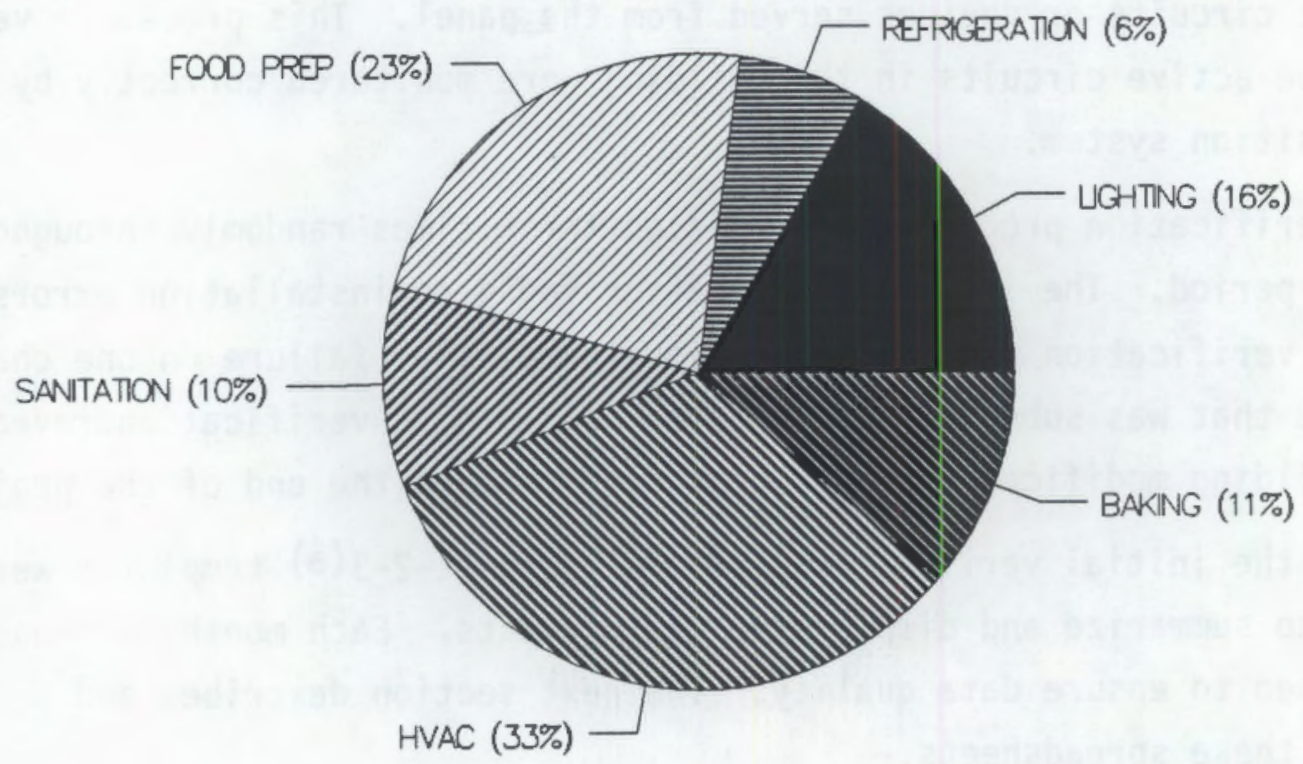

FIGURE 2.3. Electrical End-Use Shares for Prototype Dining Hall, 1986-1987

Electrical consumption totals for each month of the monitoring period are depicted in Figure 2.4. As indicated, the lighting levels are stable throughout the year, refrigeration loads are highest during summer months, food preparation energy is lowest in the winter, sanitation energy is quite variable, and electrical requirements of the HVAC system are pronounced in the summer months to satisfy the space cooling loads.

Figure 2.5 portrays the electricity consumed for interior lighting for each day in January 1987. As shown, the lighting energy for the kitchen, meal room (west dining area), and the snack line (east dining area) is nearly constant from day to day, although hours of operation do vary for weekdays and weekends.

Figure 2.6 displays the electricity consumed by the major types of food preparation equipment for each day of January 1987. In contrast to the lighting, these loads vary dramatically from day to day, in response to the particular menu and levels of food service. The steam jet cookers are the largest energy consumers, followed by the tilt grills and ovens. 


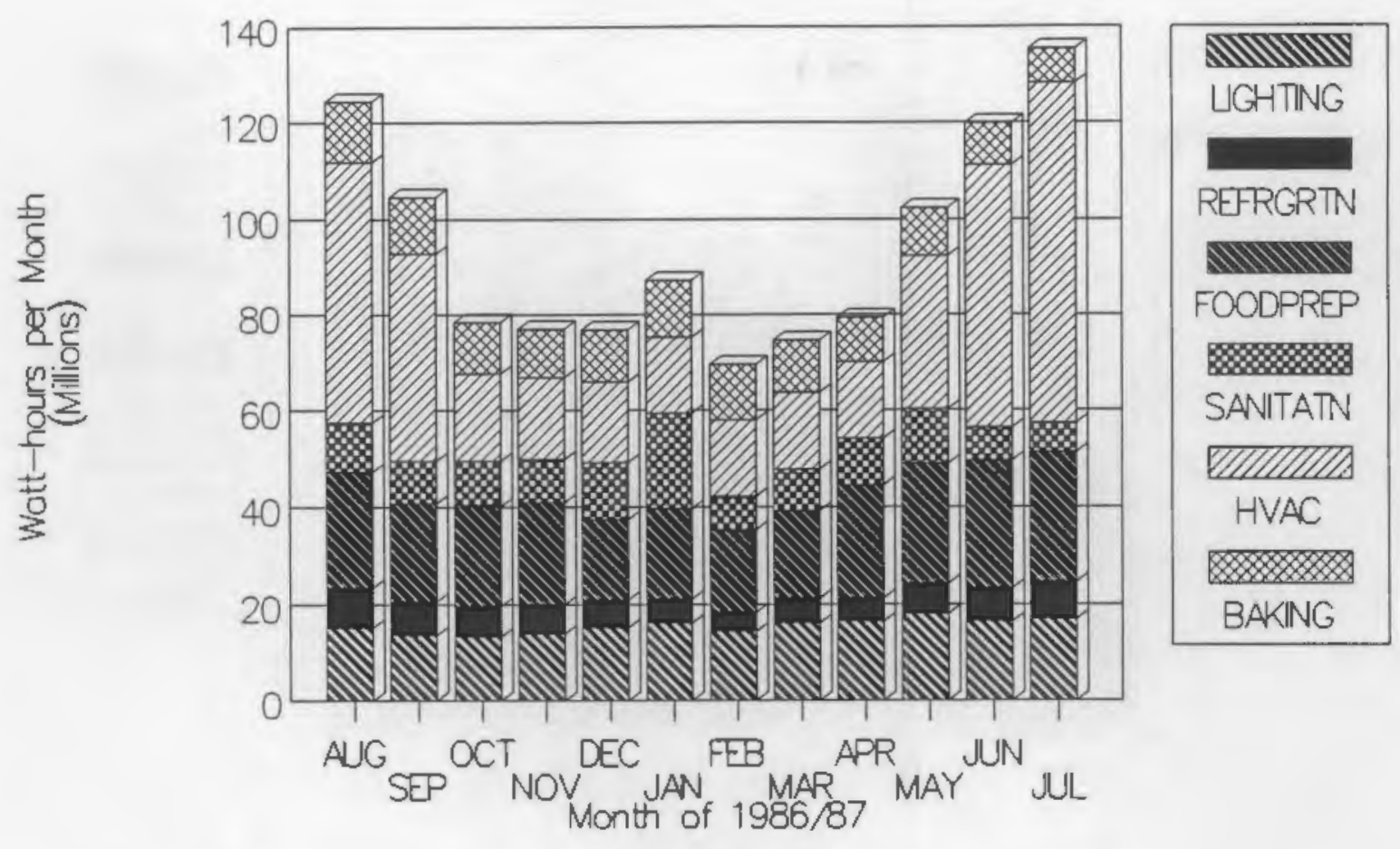

FIGURE 2.4. Monthly End-Use Electrical Consumption

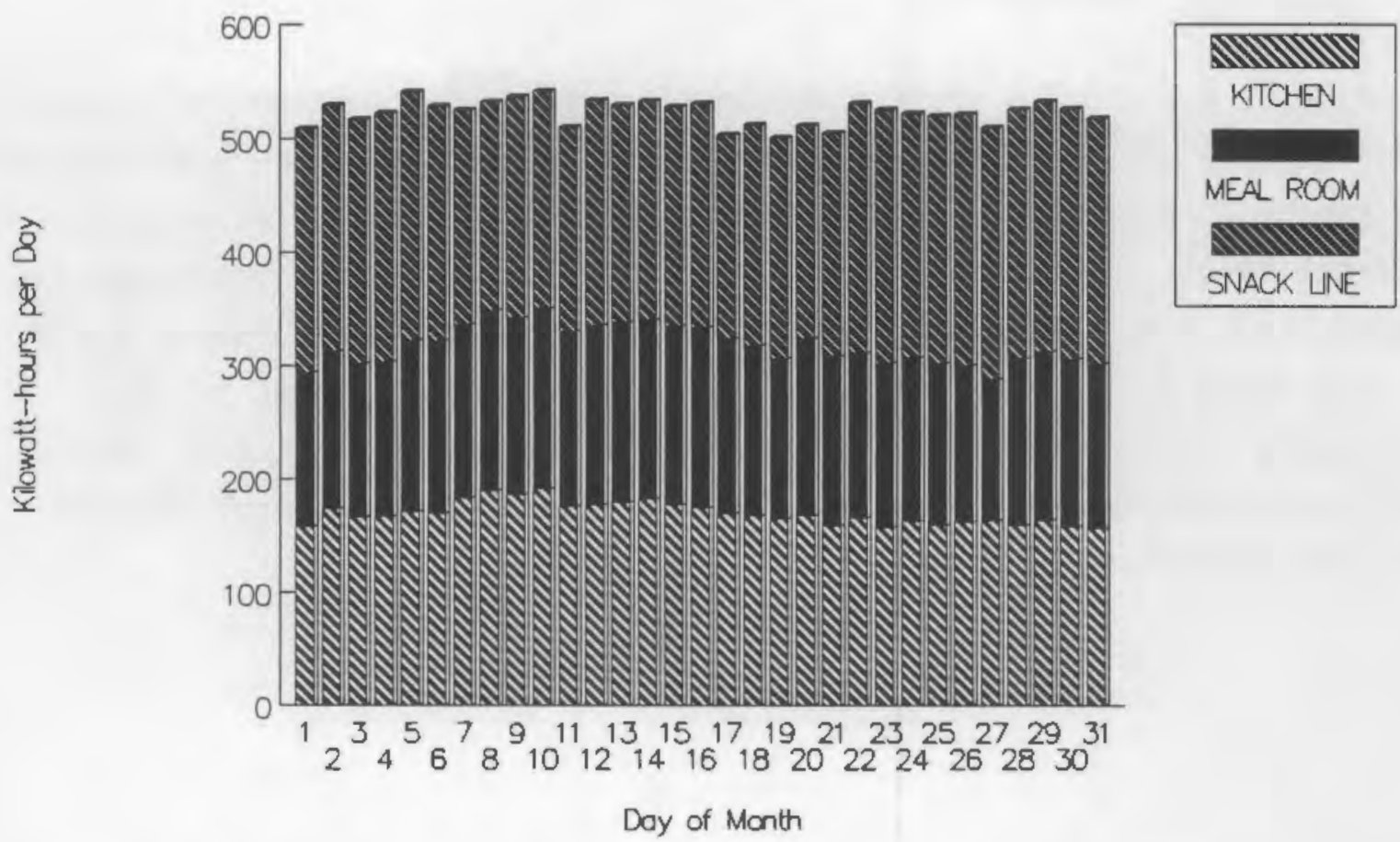

FIGURE 2.5. Electricity Consumption by Interior Lighting Components, January 1987 


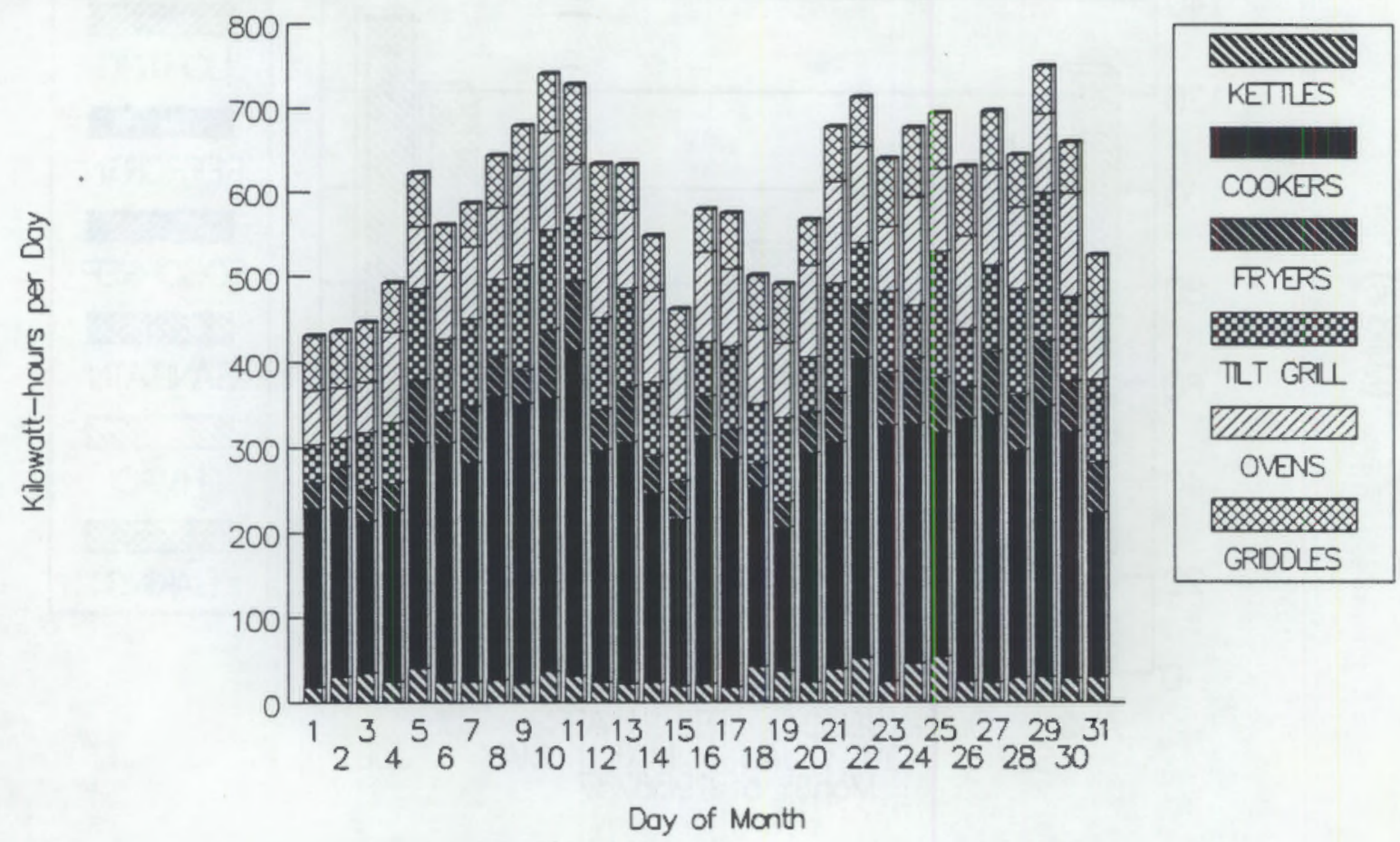

FIGURE 2.6. Electricity Consumption by Food Preparation Components, January 1987

Figures 2.7 and 2.8 profile the hourly end-use consumption for an average day in January and July 1987 . These profiles indicate that the HVAC electrical requirements are relatively flat during a particular day, but at dramatically different levels in the winter and summer. The lighting energy consumption is greatest during the hours of 0800 to 1900 and then drops to about $80 \%$ of the peak value during the early morning hours. Energy required for food preparation is greatest prior to meal service, while the sanitation and refrigeration loads are greatest following these periods. Energy used for baking is highest around midnight and noontime. 


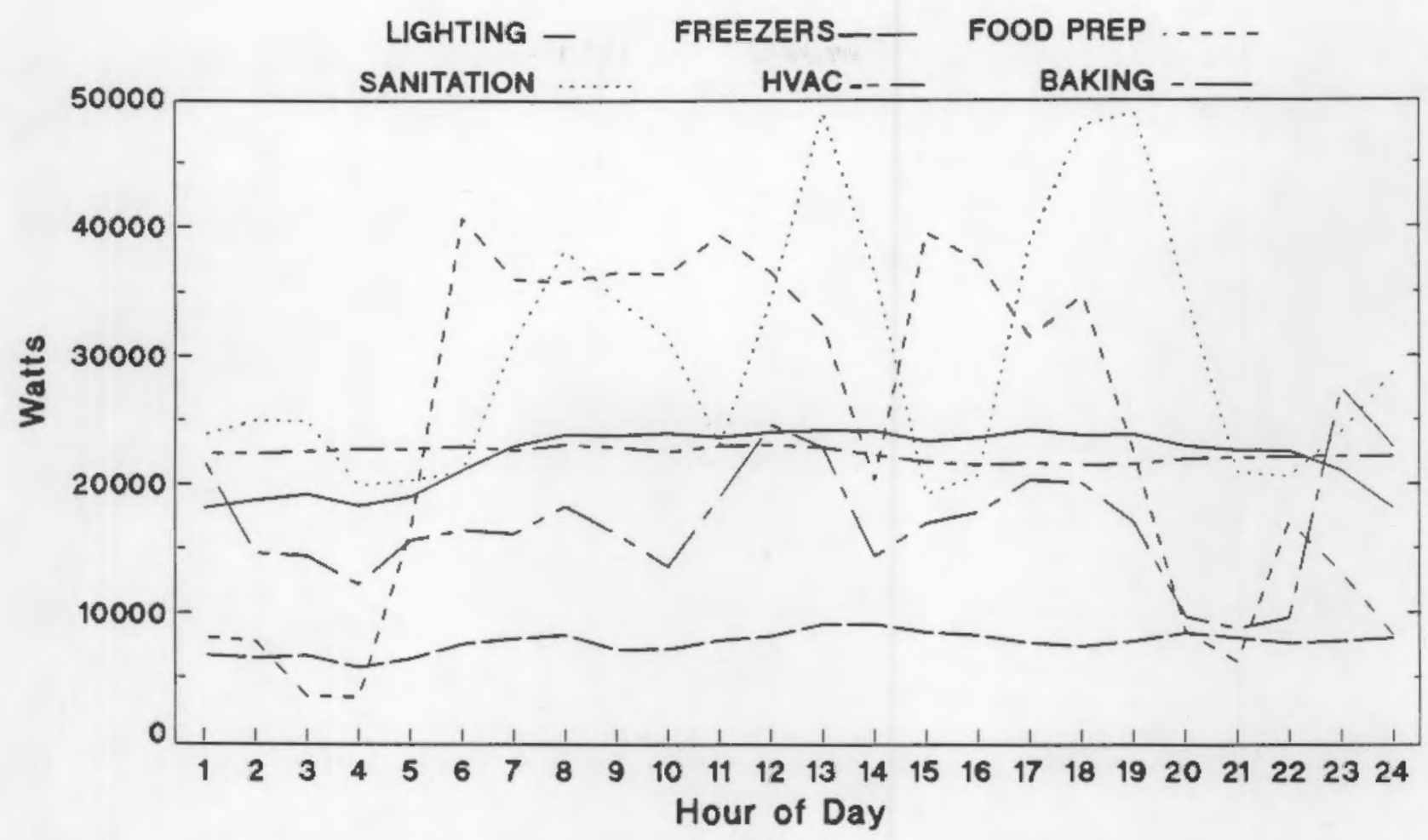

FIGURE 2.7. January Average Day End-Use Profiles

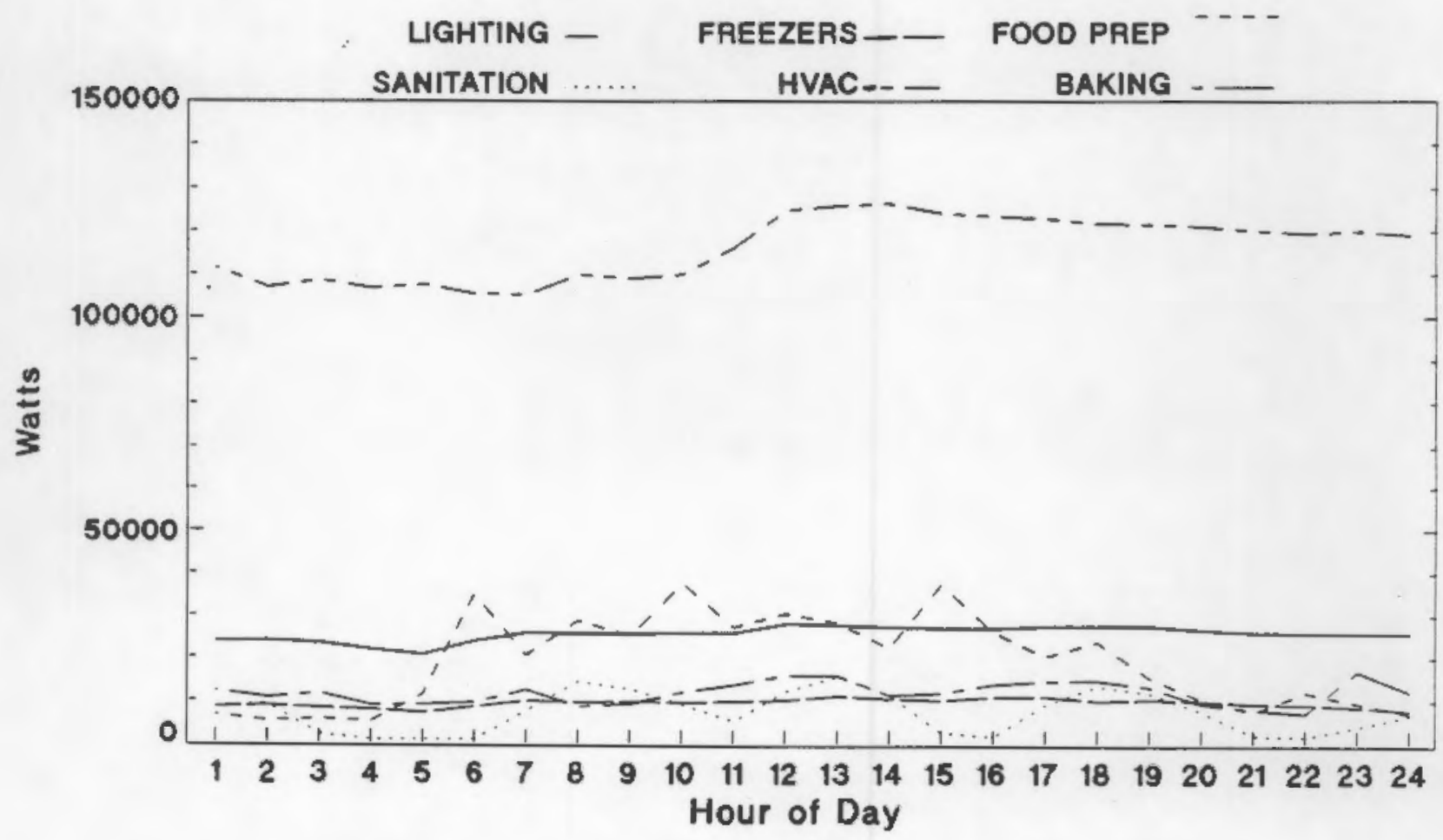

FIGURE 2.8. July Average Day End-Use Profiles 



\subsection{PROTOTYPE SIMULATION MODEL AND ANALYSIS PROCESS}

This section describes the analytical methods employed to develop estimates of baseline total energy consumption and conservation measure performance for USAF dining halls. The results achieved by using this model for the prototype dining hall are presented and compared with measurements from other previously studied restaurants.

\subsection{THE ENERGY USE SIMULATION MODEL}

The ASEAM-2.1 (A Simplified Energy Analysis Method, Version 2.1) energy simulation model was selected to estimate energy conservation potentials and to extrapolate dining hall performance to various climate regimes (ACEC Research \& Managenent Foundation 1987). This model is a modified bin method program for calculating the energy consumption of residential and commercial buildings. The method employs weather summaries that are commonly available for USAF facilities. These data indicate the number of hours during each month that temperatures lie within specific "bins." Using the data, the model estimates the heat transferred through the building shell and the ventilation system.

Once these loads are calculated, they are added to the internal gains from lights and equipment for each thermal zone. The capacity of the space heating and cooling systems for each zone is then determined, and energy requirements are calculated by considering the interior temperatures to be maintained. Finally, the performance of central plant equipment is modeled to determine the overall energy requirements of the building.

This tool was developed for the U.S. Department of Energy (DOE) and is being routinely applied to federal buildings by the Federal Energy Management Program (FEMP). The ASEAM-2.1 model was selected for the dining hall analysis because it is in the public domain, operates on personal computers, and uses algorithms recognized by the American Society of Heating, Refrigerating, and Air Conditioning Engineers (ASHRAE). The model is supported by the American Consulting Engineers Council Research and Management Foundation. 
Inputs for the model were developed from the detailed end-use energy consumption measurements and the as-built construction documents. A special program was written to develop diversity factors that are required by the model to indicate the frequency with which non-HVAC equipment is energized. These factors are usually input as "best guesses"; however, for this project they were developed from the hourly end-use consumption data.

To estimate HVAC energy use for a particular location, the model uses bin temperature data. The model provides typical weather for 46 locations. However, such data exist for hundreds of other locations and can be manually entered for specific years of interest. Because this study entailed the development of recommendations for cost-effective conservation measures, PNL researchers decided to use the model-provided weather data, which are considered typical of weather conditions for each of these locations.

For this study, the model was calibrated to the available metered data. Specifically, inputs for interior lighting and non-HVAC equipment use were derived from the end-use energy measurements. Consequently, the monthly estimates of energy consumed for these end-uses was within $5 \%$ of the measured values. The next step involved comparison of the estimated and measured energy requirement for fans and air-conditioning. This process revealed that the cooling energy calculated by the model is approximately half of that metered. It appears that either the actual coefficients of performance of the airconditioning systems are significantly lower than the design specification, or the economizers are not operating properly. Some sensitivity analyses conducted to understand this discrepancy, as well as other details relating to the model calibration, are described in Appendix A.

Once the model was calibrated to the electrical energy consumption measurements, it was run to estimate the heating energy requirements. Although this quantity was not directly measured, various heating system temperature measurements were used to ensure that the quantities of heat estimated to be provided by the system were reasonable. A heat balance was completed using a set of one-time flow measurements and 3 weeks' worth of temperature data to benchmark the heating system performance. 
Because the volume of hot water consumption was not measured, it was necessary to use data from other full service restaurants to estimate the energy requirements for this end-use. An average value of 50,000 gallons per month was assumed and adjusted according to the ratio of the measured monthly sanitation energy to the average monthly sanitation energy. This assumes that hot water use is proportional to the dishmachine usage. Next, the inlet water temperatures were estimated from mean monthly outdoor temperature data. Finally, the energy requirement for water heating was calculated assuming a $130^{\circ} \mathrm{F}$ supply temperature.

The results of the space heating and water heating energy estimates are depicted in Figure 3.1 for each month of the monitoring period. These estimates assume a $70 \%$ efficiency for the steam and hot water production. The quantities are added to the measured electrical consumption and depicted in Figure 3.2, which shows the monthly electrical baseload (total less space cooling), space cooling, space heating, and water heating. Variations in the baseload are attributable primarily to levels of food service. Figure 3.3 indicates the annual average consumption shares for each of nine energy end uses.

\subsection{COMPARISON OF THE PROTOTYPE DINING HALL ENERGY USE WITH OTHER RESTAURANTS}

Several adjustments were made to the calibrated model, to estimate the energy use of the prototype dining hall as designed. This was done to compare the energy intensity of USAF dining halls with other restaurants previously metered (Claar, Mazzucchi, and Heidell 1985) for the National Restaurant Association (NRA). The energy consumption estimates derived above were divided by the conditioned square footage and converted to thousands of British thermal units for comparison.

This comparison of energy use is presented in Table 3.1 and depicted in Figures 3.4. and 3.5. These restaurants are located in the climate type as the prototype dining hall, so the intensities for heating and cooling should be comparable. Two of the facilities are heated with natural gas; the rest are electrically heated. The gas-heated buildings are most comparable to the dining hall because of the assumed $70 \%$ conversion efficiency. 


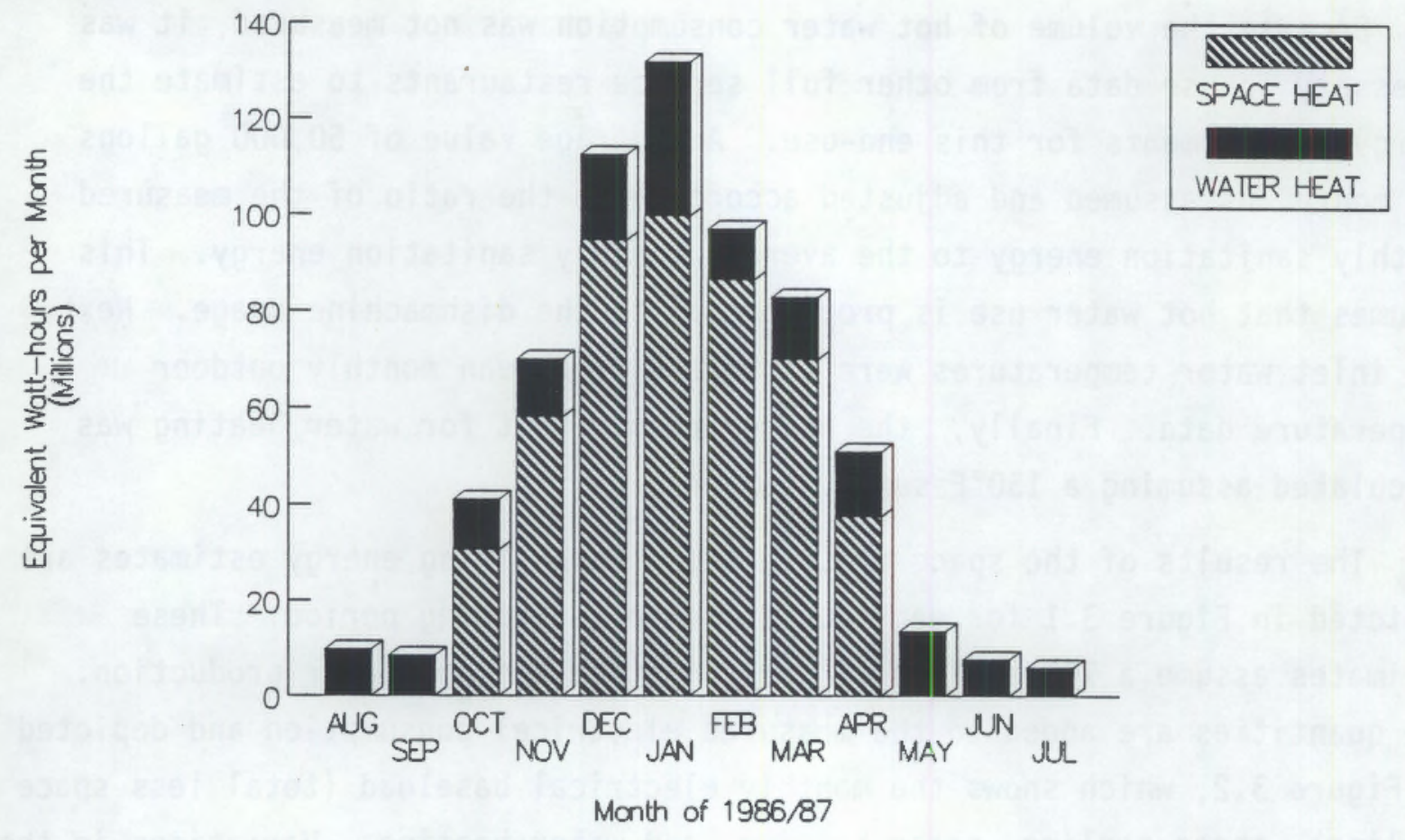

FIGURE 3.1. Estimated Energy Consumption for Steam Production

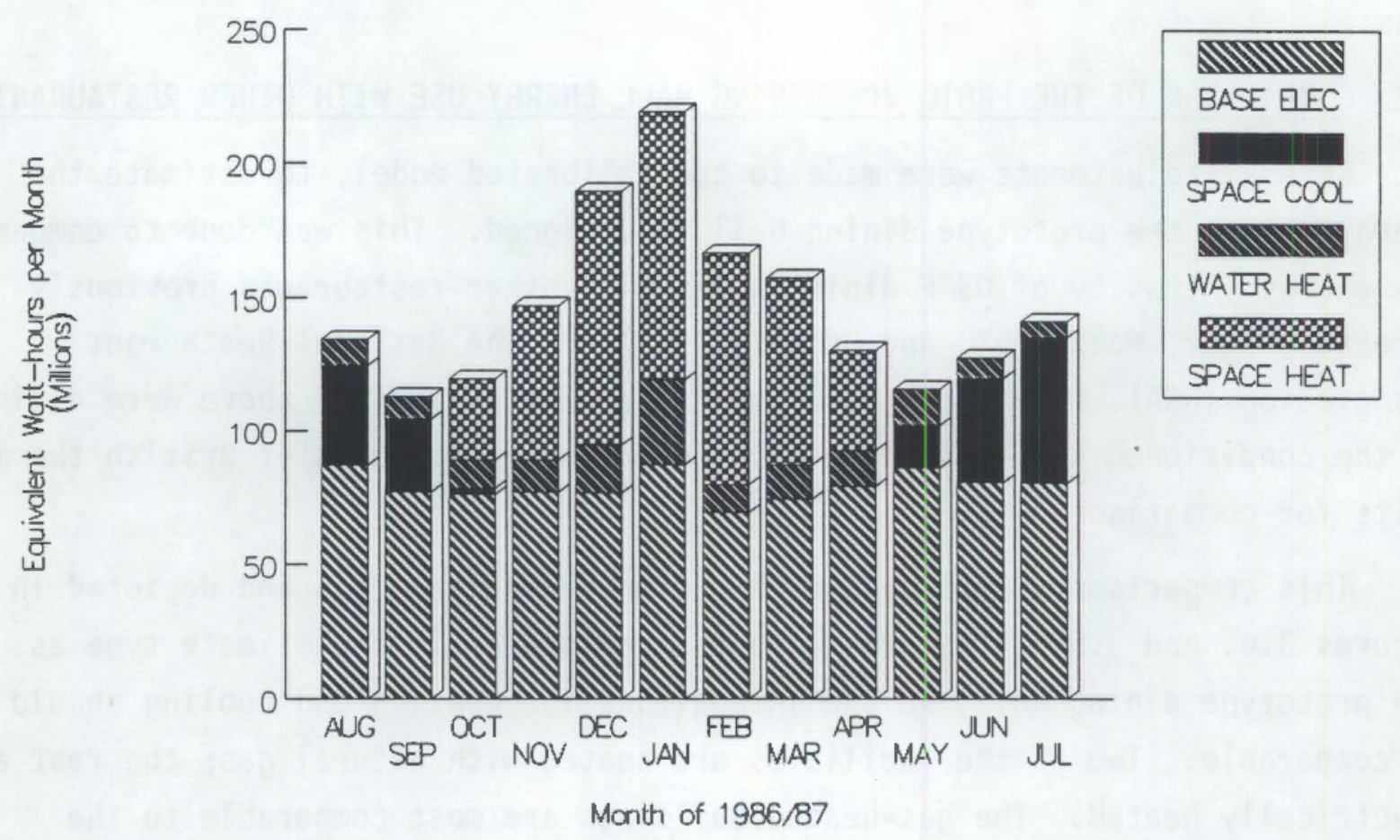

FIGURE 3.2. Estimated Total Monthly Energy Consumption 


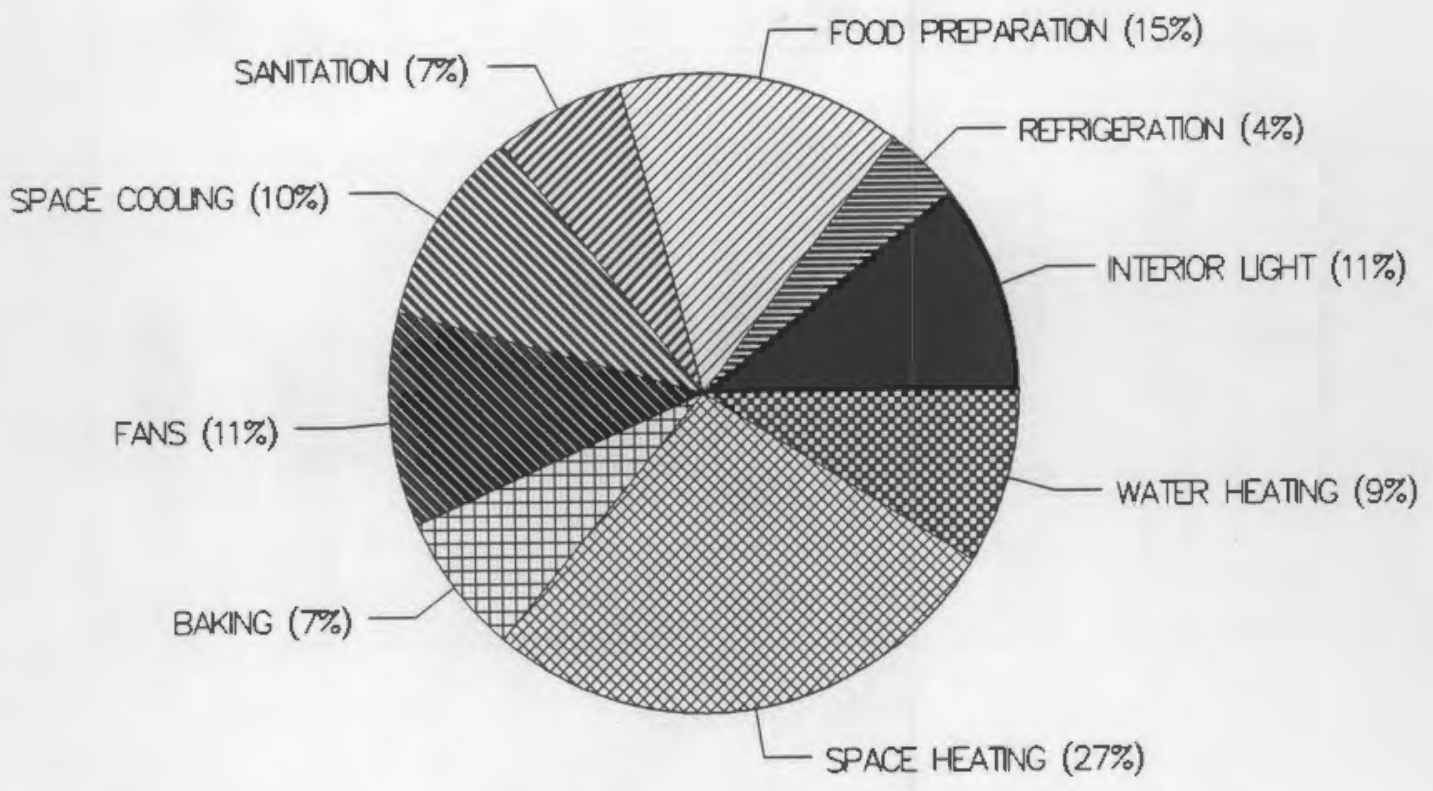

FIGURE 3.3. Estimated Energy Consumption Shares by End Use

TABLE 3.1. Comparison of USAF Dining Hall End-Use Enerav Intensities

\begin{tabular}{|c|c|c|c|c|c|c|c|}
\hline FOOO SERVICE & SQUARE & |ENERGY INTE & ITY & (Thousand & Btu per Squa & re Foot $p$ & er Year) \\
\hline TYPE & | FOOTAGE & | $\cdots+$ & -- & encon & 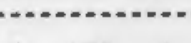 & 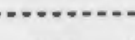 & $-\infty$ \\
\hline & | & | FD.PRP | & SANIT & REF & LTG & HVAC & Tот \\
\hline AST FOOO LIMITED & 3100 & | 322.77 | & 66.41 & 30.40 & | 139.76 | & 171.00 & 730.34 \\
\hline FAST FOCO EXPANDED & 2750 & | 216.17 | & 42.13 & 33.27 & 68.051 & 263.27 & 622.87 \\
\hline |CAFETERIA & 10150 & | 242.74 | & 177.64 & 20.08 & $43.85 \mid$ & 128.40 & 612.72 \\
\hline |FULL SERVICE EXPANDE & 9500 & | 178.48 | & 132.03 & 37.20 & 61.841 & 139.64 & 549.18 \\
\hline |PI2ZA & $22 \pi 5$ & $159.00 \mid$ & 93.80 & 46.79 & 65.301 & 150.50 & 515.38 \\
\hline |FULL SERVICE LIMITED & 6770 & 99.551 & 84.72 & 41.56 & 73.961 & 107.71 & 407.50 \\
\hline |COFFEE SHOP & 4210 & 114.27 I & 85.85 & 13.89 & 64.831 & 111.87 & 390.71 \\
\hline ISAF DINING HALL & 12000 & | 108.94 | & 77.51 & 20.68 & 52.97 I & 220.75 & 480.86 \\
\hline
\end{tabular}

From the comparison shown in Figure 3.4 , it can be seen that the dining hall energy use per square foot is similar to that of the other full service facilities, ranging from 400 to $500 \mathrm{Btu} \times 103 / \mathrm{ft2} / \mathrm{yr}$. Energy consumption for the dining hall HVAC is higher than the other restaurants on a percentage basis because of the extended hours of operation and the apparent inefficiency of the air conditioning systems. Nonetheless, the opportunities for energy 


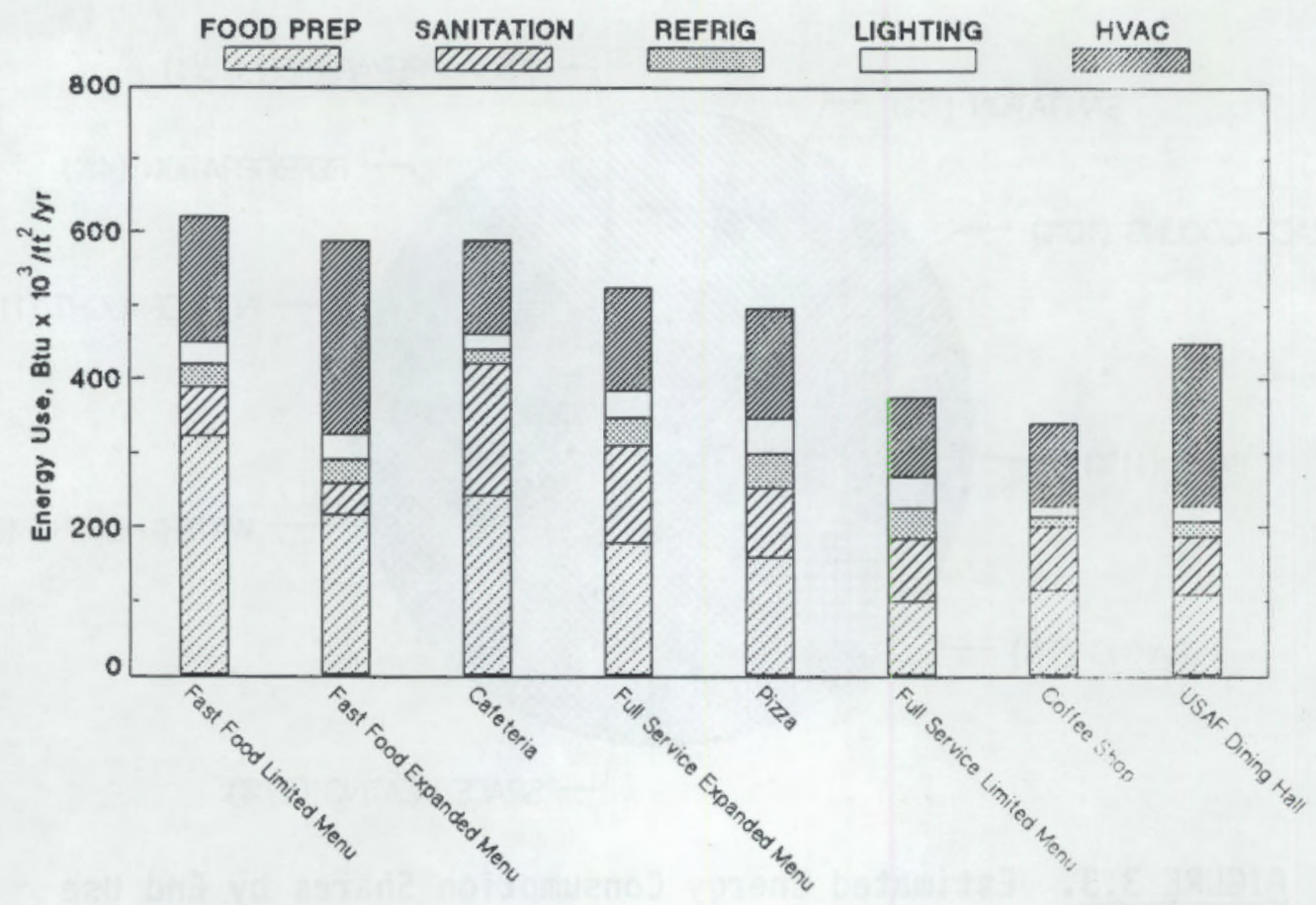

Restaurant Type

FIGURE 3.4. Comparison of Restaurant Energy Use Intensities by End Use

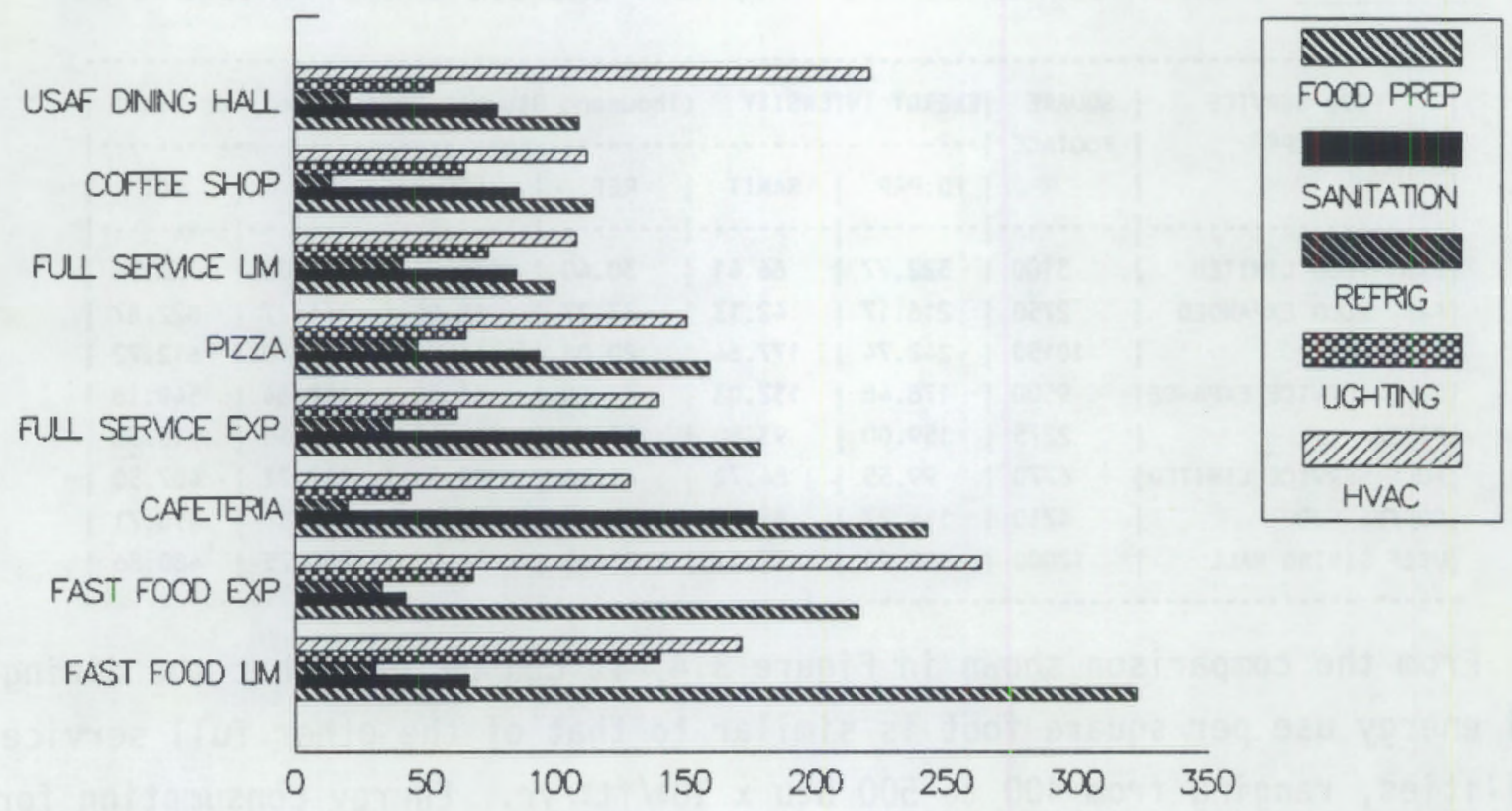

Thousond Btu per Square Foot per Year

FIGURE 3.5. Comparative Restaurant Energy Use Intensities by Individual End Use 
conservation would appear to be similar to those indicated by the previous work.

\subsection{ANALYSIS OF WEATHER EFFECTS ON ENERGY CONSUMPTION}

Having calibrated the model to the available measured data, and achieving a satisfactory comparison of the prototype energy use estimates with other metered facilities, the model was ready for the conduct of sensitivity analysis. This section describes the results of a thorough examination of how weather affects energy use in the prototype dining hall.

The base case model was run using weather data from all 46 weather locations provided with the ASEAM model. The results of this analysis are summarized in Table 3.2 and Figure 3.6. These data show that approximately $70 \%$ of dining hall energy use is not related to weather. Energy for space heating constitutes $32 \%$ of total energy consumption in Bismark, North Dakota, while space cooling constitutes up to $16 \%$ of total requirements in Miami, Florida. Space heating and cooling requirements for all other locations are smaller on a percentage basis. Consequently, while HVAC energy does vary dramatically by location, its significance is reduced in light of the predominant levels of process energy requirements.

Four climate domains were established to incorporate this weather sensitivity into the simple analysis method. These climate domains were selected based upon the estimated energy requirements for space heating and space cooling for the 46 available weather locations. The domains can be characterized as follows:

- cold - high heating, low cooling

- cool - high heating, moderate cooling

- warm - moderate heating, high cooling

- hot - low heating, high cooling.

Figure 3.7 displays these data by positioning the index number for each weather location, as identified in Table 3.2., according to the annual heating and cooling energy consumption estimates. Within each of these domains a weather location in the center of the cluster was selected to conduct the energy conservation assessments. 
TABLE 3.2. Summary of Consumption for 46 U.S. Cities

\begin{tabular}{|c|c|c|c|c|c|c|c|}
\hline $\begin{array}{l}\text { LOCATION } \\
\text { STATE } \\
======\end{array}$ & $\begin{array}{l}\text { LOCATION } \\
\text { CITY } \\
=======\end{array}$ & $\begin{array}{l}\text { LOCATION } \\
\text { INDEX } \\
=======\end{array}$ & $\begin{array}{l}\text { CLIMATE } \\
\text { TYPE } \\
=======\end{array}$ & $\begin{array}{l}\text { HEAT } \\
\text { MBTU/YR } \\
=======\end{array}$ & $\begin{array}{r}\text { COOL } \\
\text { MBTU/YR } \\
======\end{array}$ & $\begin{array}{c}\text { OTHER } \\
\text { MBTU/YR } \\
=======\end{array}$ & $\begin{array}{l}\text { TOTAL } \\
\text { MBTU } / \text { YR } \\
=======\end{array}$ \\
\hline ALABAMA & BIRMINGHAM & 1 & WARM & 680 & 509 & 2845 & 4034 \\
\hline $\begin{array}{l}\text { RKANSAS } \\
\text { RIZONA }\end{array}$ & LITTLE ROCK & 2 & WARM & 778 & 550 & 2858 & 4186 \\
\hline $\begin{array}{l}\text { ARIZONA } \\
\text { CAL IFORNIA }\end{array}$ & PHOENIX & 3 & HOT & 396 & 707 & 2847 & 3951 \\
\hline CALIFORNIA & LOS ANGELES & 4 & WARM & 393 & 471 & 2834 & 3699 \\
\hline COLORADO & DENVER & 5 & $\mathrm{COOL}$ & 1458 & 286 & 2879 & 4623 \\
\hline A & MIAMI & 6 & HOT & 109 & 804 & 2798 & 3710 \\
\hline IDA & TALLAHASSEE & 7 & НОT & 413 & 631 & 2830 & 3874 \\
\hline FLORIDA & TAMPA & $8^{\star}$ & HOT & 240 & 716 & 2820 & 3776 \\
\hline IIA & ATLANTA & $9^{\star}$ & WARM & 705 & 482 & 2838 & 4025 \\
\hline IOWA & DES MOINES & 10 & $\mathrm{COOL}$ & 1546 & 339 & 2872 & 4757 \\
\hline IDA & BOISE & 11 & $\mathrm{COOL}$ & 1380 & 284 & 2877 & 4541 \\
\hline ILLINOIS & CHICAGO & 12 & $\mathrm{COOL}$ & 1451 & 312 & 2863 & 4625 \\
\hline INOIANA & INDIANAPOLIS & 13 & $\mathrm{COOL}$ & 1324 & 351 & 2862 & 4537 \\
\hline KANSAS & DODGE CITY & 14 & $\mathrm{COOL}$ & 1249 & 396 & 2872 & 4516 \\
\hline LOUISIANA & LAKE CHARLES & 15 & HOT & 415 & 648 & 2829 & 3892 \\
\hline MASSACHUSETTES & BOSTON & 16 & $\mathrm{COOL}$ & 1309 & 294 & 2866 & 4469 \\
\hline MAINE & PORTLAND & 17 & COLD & 1735 & 235 & 2878 & 4848 \\
\hline MICHIGAN & DETROIT & 18 & $\mathrm{COOL}$ & 1533 & 287 & 2867 & 4687 \\
\hline MINNESOTA & MINNEAPOLIS & 19 & COLD & 1940 & 280 & 2878 & 5097 \\
\hline MISSOURI & KANSAS CITY & 20 & $\mathrm{COOL}$ & 1150 & 436 & 2866 & 4452 \\
\hline MISSOURI & ST. LOUIS & 21 & $\mathrm{COOL}$ & 1149 & 402 & 2862 & 4413 \\
\hline MONTANA & GREAT FALLS & $22^{*}$ & COLD & 1879 & 218 & 2877 & 4973 \\
\hline NEBRASKA & OMAHA & 23 & $\mathrm{COOL}$ & 1452 & 360 & 2870 & 4681 \\
\hline NORTH CAROLINA & RALEIGH & 24 & WARM & 853 & 446 & 2847 & 4146 \\
\hline NORTH DAKOTA & BISMARK & 25 & COLD & 2215 & 253 & 2891 & 5359 \\
\hline NEW MEXICO & ALBEQUERQUE & 26 & $\mathrm{COOL}$ & 1037 & 395 & 2867 & 4298 \\
\hline NEVADA & LAS VEGAS & 27 & WARM & 640 & 548 & 2861 & 4049 \\
\hline NEW YORK & NEW YORK & 28 & $\mathrm{COOL}$ & 1139 & 344 & 2861 & 4344 \\
\hline $\mathrm{OHIO}$ & CLEVELAND & 29 & $\mathrm{COOL}$ & 1426 & 293 & & 4582 \\
\hline $\mathrm{OHIO}$ & DAYTON & $30^{\star}$ & $\mathrm{COOL}$ & 1317 & 33 & 2865 & 4517 \\
\hline OKLAHOMA & OKLAHOMA CITY & 31 & WARM & 924 & 487 & 2861 & 4272 \\
\hline OREGON & MEDFORD & 32 & $\mathrm{COOL}$ & 1244 & 294 & 2882 & 4420 \\
\hline OREGON & PORTLAND & 33 & $\mathrm{COOL}$ & 1081 & 267 & 2872 & 4220 \\
\hline PENNSYLVANIA & PITTSBURG & 34 & COOL & 1410 & 286 & 2865 & 4562 \\
\hline SOUTH CAROLINA & CHARLESTON & 35 & WARM & 539 & 579 & 2835 & 3953 \\
\hline TENNESSE & NASHVILLE & 36 & WARM & 879 & 458 & & 4188 \\
\hline TEXAS & AMARILLO & 37 & $\mathrm{COOL}$ & 1049 & 42 & 2864 & 4333 \\
\hline TEXAS & BROWNSVILLE & 38 & HOT & 198 & 77 & 2813 & 3789 \\
\hline TEXAS & DALLAS & 39 & WARM & 587 & 589 & 2844 & 4020 \\
\hline TEXAS & EL PASO & 40 & WARM & 627 & 524 & 2846 & 3997 \\
\hline TEXAS & SAN ANTONIO & 41 & HOT & 434 & 641 & 2838 & 3913 \\
\hline UTAH & SALT LAKE CITY & 42 & $\mathrm{COOL}$ & 1371 & 311 & 2879 & 4561 \\
\hline WASHINGTON & $D C$ & 43 & $\mathrm{COOL}$ & 996 & 400 & 2852 & 4248 \\
\hline WASHINGTON & SEATTLE & 44 & $\mathrm{COOL}$ & 1194 & 19 & 2860 & 4249 \\
\hline WISCONSIN & MADIS & 45 & COLD & 1832 & 276 & 2877 & 4985 \\
\hline WYOMING & CHEYENNE & 46 & COLD & 1746 & 215 & 2882 & 4843 \\
\hline
\end{tabular}




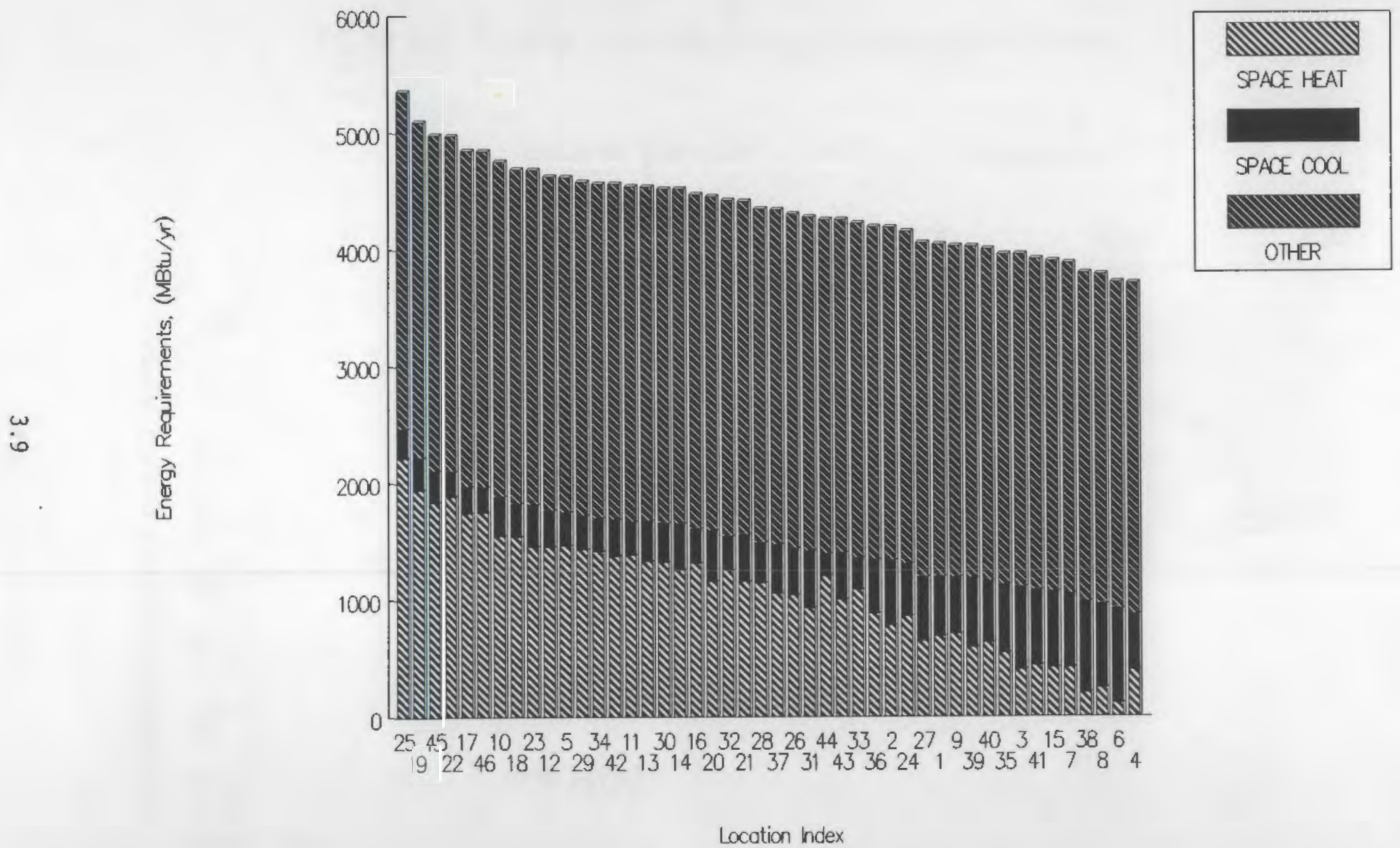

FIGURE 3.6. Impact of Climate Variation on End-Use Energy Consumption 


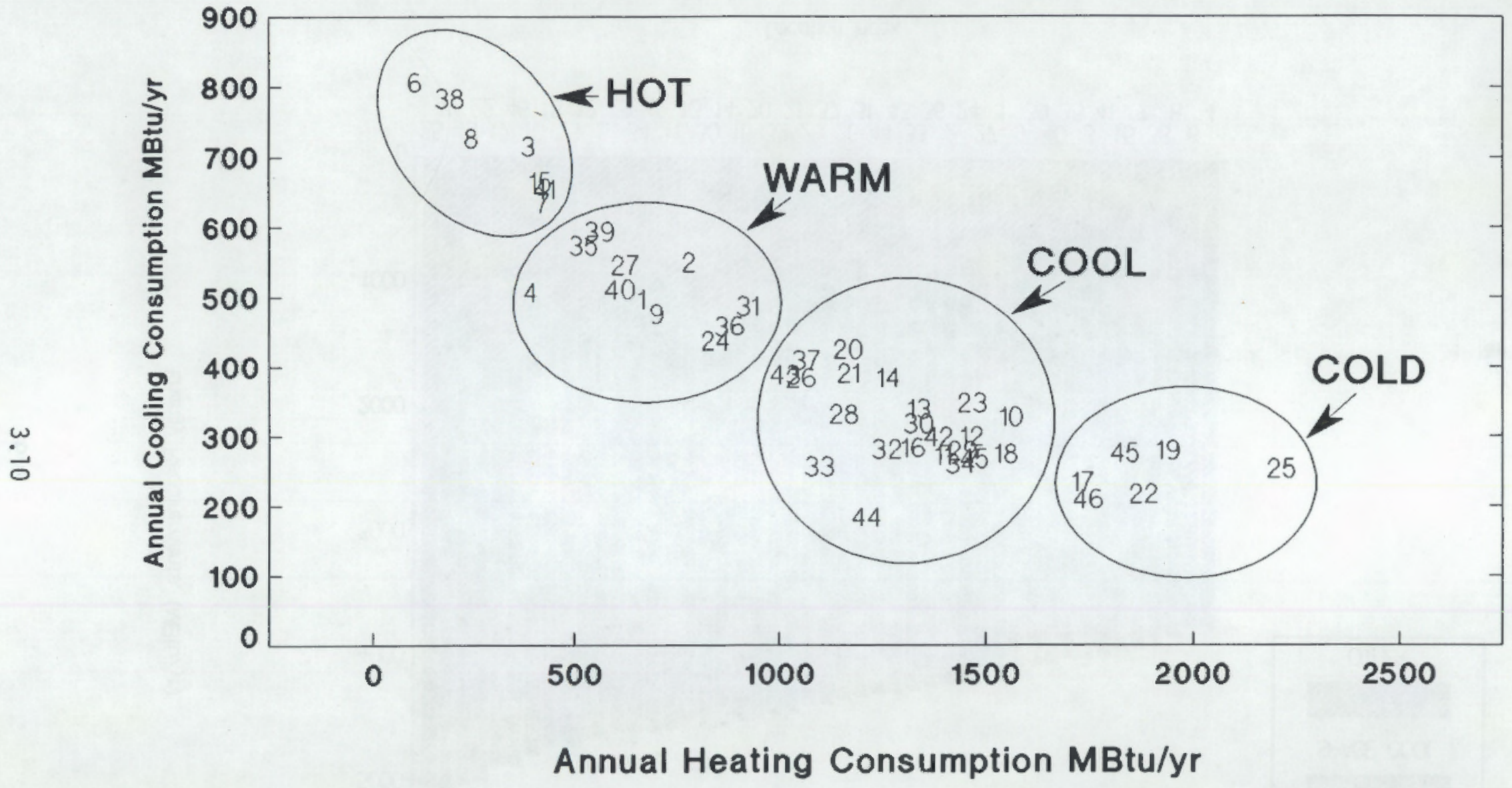

FIGURE 3.7. Climate Areas for the Simplified Analysis Method 
The weather file selected to represent each climate domain and the locations falling within each domain are listed in Table 3.2 in the Climate Type column. An asterisk is placed by those sites selected to represent each of the four climate types for purposes of the simplified analysis method. 



\subsection{ENERGY CONSERVATION MEASURES FOR DINING HALLS}

This section describes the energy conservation opportunities applicable to USAF dining halls and approaches to analyze their cost-effectiveness. The performance of many measures can be assessed in a generic fashion, while others are so site-specific that a case-by-case analysis is required. The section begins with an overview discussion of the types of conservation opportunities and analysis methods. The specific conservation opportunities covered by the simple analysis method are then described.

Conservation opportunities are organized by energy end-use category. Within each category, the magnitude and variability of energy consumption is first discussed to place the detailed measure descriptions that follow in context.

\subsection{Food Preparation}

Energy use by food preparation equipment was responsible for $34 \%$ of the electrical consumption of the prototype dining hall. Eleven percent was devoted to the baking ovens and equipment, and $23 \%$ to the mix of kettles, steam cookers, fryers, tilt grills, ovens, and griddles.

The best conservation advice here is to keep the equipment clean, maintained, and turned of $f$ when not in use. Energy management systems, which range in sophistication from simple time clocks to microcomputers, can affect sizable savings here, but so can employee effort. The metered data, however, indicated few instances of equipment being left on.

Posting and adhering to specific equipment start up procedures can produce considerable savings. In some cases, equipment is turned on well in advance of actual need, resulting not only in direct energy waste, but also in additional air conditioning loads as the space is heated.

Opportunities exist for savings by careful selection of food preparation equipment. New technologies, proper equipment sizing and placement, and efficiency features of food preparation equipment should be considered carefully before procurement. Examples of new technologies include microwave ovens, convection ovens, and infrared fryers. These technologies may affect 
the appearance and quality of certain food types; consequently, they should be tested before routine acquisition.

Specification of several small pieces of equipment is generally more efficient than one large unit. This is because the capacity of equipment applied to a particular operation can be better matched to the actual requirement. In addition, this practice reduces reliance on a given device so that, in the event of equipment failure, the other units can be more heavily used until a repair is affected. The placement of equipment can affect overail efficiency by facilitating the removal of excess heat through exhaust hoods.

Certain features of food preparation devices can contribute to energy efficiency. Unfortunately, standardized test procedures for food preparation equipment efficiency are not currently available so it is difficult to verify vendor claims of energy savings. Standards and test procedures are currently being explored by the Electric Power Research Institute (EPRI), American Society for Testing and Materials (ASTM), and DOE, so verification of claimed energy savings should be possible in the future. However, some features can be judged intuitively, such as increased insulation on ovens, efficient motors for mixers, and covers for cookers and fryers.

The simple analysis procedure quantifies the value of energy savings from a $10 \%$ improvement in food preparation equipment efficiency, as well as a $10 \%$ reduction in food preparation equipment energy use during the unoccupied period. These reductions relate to use of more efficient food preparation equipment and better control of food preparation equipment, respectively. Savings are induced in two ways: directly through reduction of food preparation equipment energy consumption, and indirectly through reductions in space cooling requirements if the equipment is ocated in an air conditioned space. If adopted, these measures may increase space heating requirements because of the reduction in internal gains. The simple analysis method accounts for all of these effects, which vary from one climate domain to another. 


\subsection{Sanitation}

Approximately $20 \%$ of the prototype energy consumption stems from sanitation requirements for water heating, dishwashing, and garbage disposals. The lion's share of this energy is to support the dishwashing function, where approximately half of the energy is required to provide $130^{\circ} \mathrm{F}$ water to the dishmachine, and half is used by the dishmachine and its dedicated booster heater.

Conversion of high-temperature dishwashers to low-temperature chemical sanitizers can result in savings, principally due to the elimination of the booster heater. This requires more thorough scraping of dishes before sanitizing and increased machine maintenance and chemical costs. The sanitizer may also discolor soft metals, such as pewter and aluminum. Nonetheless, the energy savings can be very substantial, on the order of 25 to $50^{\circ}$ depending upon equipment type and use.

The other major area for sanitation energy savings is improving the energy efficiency of the domestic hot water system. Several technologies can be considered here, including insulation of hot water tanks and pipes, scheduling of the water heater and hot water circulation pump, waste heat recovery, and use of heat pump water heaters. The hot water tank and pipes in the prototype facility are insulated. If the pipes or tank are not insulated, savings on the order of $10 \%$ of water heating requirements can result.

Scheduling of the water heater and pump does not appear to be particularly effective for USAF dining halls due to the extended hours of operation and the need for hot water even in the early morning to support the baking function. Recovery of heat from refrigeration condensers is often practical, particularly if the compressors are close to the water supply. This technology is not recommended for retrofit applications, however, because of the need to install special condensers and heat exchangers customized to the existing equipment. This technology should be considered for new building applications, however.

The most promising method to reduce water heating requirements is the use of heat pump water heaters, particularly if water is now heated 
electrically. The heat pump effectively moves the heat of warm air into water, with a coefficient of performance of 2.0 to 3.0 . This means that electrical consumption of water heaters $c$ an be reduced by 50 to $65 \%$. The performance is greatest when the water heater is situated in a warm area, such as the baking room. As an added benefit, the heat pump cools the air from which the heat is removed, acting the same as an air conditioner.

Another approach to reduce water heating requirements is to use pointof-use water heaters. These devices are located adjacent to the hot water fixtures and provide hot water on demand. In the case of the prototype dining ha11, these water heaters are appropriate for the bathrooms. In this way, the energy required by the hot water circulation pump, as well as the heat loss of the pipes, can be conserved. For buildings yet to be constructed, additional savings can result by obviating the need for hot water pipes to these areas.

The simple analysis method includes one sanitation conservation measure related to retrofit of a heat pump water heater. This device is assumed to reduce the domestic heating requirement by $50 \%$. The additional benefit of cooling for the kitchen is not quantified, as it is assumed that the heater is installed in an area that is not mechanically cooled. Nonetheless, the chefs will benefit by having a more comfortable workplace.

\subsection{Refrigeration}

The energy required for freezing and refrigeration is approximately $6 \%$ of the prototype dining hall electrical consumption. Although this is a small share, numerous energy conservation opportunities exist.

Periodic maintenance on refrigeration equipment should include ensuring tightness of door gaskets and closures, cleanliness of evaporator and condensing coils, and adequate freon levels.

For walk-in refrigeration units, products should not impede the air flow within the unit and around the fan. Loading periods can be scheduled to reduce the number of times the door is opened, and self-closing doors can be effective if they are habitually left open. Employees can be trained to quickly locate items within the unit to minimize open-door "shopping." 
Vinyl strip curtains on walk-in refrigeration units can significantly reduce energy requirements by reducing compressor run-times by up to $30 \%$. The effectiveness of these curtains is sometimes negated by employees who tie them back to provide easier access. With proper training management oversight, this should not be a problem.

Ice machines can be considerable energy consumers; however, in the prototype dining hall, only small machines are used. It is seldom costeffective to replace machines solely for energy efficiency, but if a new machine is needed, consideration should be given to efficiency features. Single-head production machines are usually more efficient than smaller stacked heads. Coils should be kept clean on air-cooled machines, and valves should be checked on water-cooled machines to avoid losing condensing water, a common problem that can waste up to 100,000 gallons per month. While water-cooled equipment is more energy-efficient, the value of water and costs of disposal may offset these energy savings.

Passive double-walled heat exchangers can be used to cool refrigeration condensers and preheat domestic hot water. The feasibility and costeffectiveness of this strategy in retrofit applications is very site-specific, and may void equipment warranties. The water heating load is sufficiently large to effectively use this "free-heat" most of the time.

Careful location of equipment compressors and condensers can significantly affect energy requirements. These components should be located in cool, shaded areas when possible. However, they should not be placed in mechanically cooled areas, as they will impose an additional burden on the space cooling equipment.

The simple analysis method includes two conservation measures related to refrigeration. First, a $10 \%$ reduction in refrigeration capacity is modeled to correspond to the saving resulting from installation of strip curtains on the walk-in coolers and freezer. Second, a $25 \%$ reduction of refrigeration system energy use is modeled to correspond to the improved efficiency of using water-cooled condensers for the walk-in units. As mentioned above, this feature can be combined with a heat recovery system to preheat domestic hot water. Additional reductions may be cost-effective for new buildings, as the 
incremental costs of many of the above-mentioned conservation measures can be quite low. Furthermore, for slightly higher capital costs, more efficient compressors and condensers can be obtained.

\subsection{Lighting}

Lighting for the prototype dining hall consumes $16^{\circ}$ of the electricity. Approximately $150 \mathrm{kWh} /$ day are consumed in the kitchen area and $150 \mathrm{kWh} /$ day in the west dining area by the fluorescent fixtures. The east dining area, with its decorative incandescent fixtures, consumes approximately $200 \mathrm{kWh} / \mathrm{day}$.

Energy conservation opportunities for this end use can occur in three ways: 1) specifying more efficient lamps and fixtures, 2) reducing hours of operation, and 3 ) reducing lighting levels. Caution must be exercised here to ensure that lighting quantities and qualities are sufficient for the particular task requirements. New efficient technologies should be tested and evaluated in actual application prior to routine procurement.

The savings from use of more efficient lamps is revealed by the difference in lighting between the east and west dining areas. These areas are of similar size and use. However, the east dining area uses about $33 \%$ more energy for its incandescent lamps than do the fluorescent lamps in the west area. Energyefficient fluorescent lamps now available require only $34 \mathrm{~W}$ for the equivalent lighting output of a $40-W$ lamp. Complete retrofit of such lamps can result in a $15 \%$ energy reduction. Replacing incandescent bulbs with screw-in fluorescent units, and replacing $R$ or PAR floodlights with ER or ellipsoidal reflector floodlights, can be very cost-effective. Another efficiency improvement can be obtained by replacing the ballasts associated with fluorescent fixtures. New electronic ballasts are available that can reduce the energy consumption of a fluorescent fixture by 18 to $25 \%$. These ballasts can also improve the quality of light by increasing the "flicker rate" so as to be unnoticeable. A third method to increase lighting efficiency is to use more efficient fixtures to focus and direct the light to the working surfaces. Use of parabolic reflectors and efficient lenses can reduce the number of fixtures required to illuminate a space. While this may be cost effective for 
new designs, the capital costs of fixture replacements for energy savings alone are likely to be prohibitive.

The second method to reduce lighting energy requirements is through better scheduling. The hourly measurements as depicted in Figures 2.7 and 2.8 reveal that lighting during the early morning hours drops to only about $80 \%$ of the peak values. This is surprising, because no one is using the dining areas that constitute approximately two-thirds of the consumption for lighting during the early morning hours. Better lighting layouts and zone-controlled switches can facilitate better modulation of lighting energy to zone lighting requirements, if staff are trained to use the switches. Motion detectors are available to automatically extinguish lights when zones are unoccupied and these can be very cost effective if personnel habitually leave lights on. Considerable savings can also be achieved by effective use of daylight with fixtures which dim in response to available natural light. Although this strategy works best when incorporated into the initial design of the building to ensure effective natural light distribution, it can also be cost-effective for perimeter areas adjacent to windows for retrofit applications.

The third method to reduce lighting energy requirements is to reduce lighting levels. Many areas may be overlit in consideration of the task requirements and the escalating costs of electricity over the past decade. Care must be exercised to ensure that the lighting levels are maintained for safety: IES publishes guidelines for minimum safe lighting levels for particular tasks (IES 1981). In most dining establishments, considerable savings can be obtained though effective positioning of fixtures to achieve good atmosphere and contrast. If there are areas which are used for various activities, it may be desirable to use dimmers or multiple switches to permit lighting levels to be matched to the actual demands. One popular strategy is to separately wire and switch the middle tube of three tube fluorescent fixtures to provide three levels of light associated with the center tube, the two outside tubes, and finally all three tubes. Although such rewiring may be difficult to retrofit, the incremental costs for new designs are much smaller. This strategy would appear to be ideal for the dining hall, as lighting at night and in the early morning could be reduced by approximately 
two-thirds for security purposes. Separate fixtures for the baking area could be kept on to ensure adequate lighting for this early-morning task.

\subsection{Heating, Ventilating, and Air Conditioning}

Heating, ventilating, and air conditioning accounted for approximately $33 \%$ of the prototype dining hall electrical consumption and over $80 \%$ of the steam energy consumption. Because these demands are dependent on climate, a sensitivity analysis was carried out. This analys is revealed that consumption for HVAC can constitute from 25 to $50 \%$ of dining hall energy requirements. As such, it is an area with considerable conservation potential and a wide variety of conservation opportunities. These three end uses are discussed together because the performance of each component is linked to the others.

Conservation opportunities can be classified into three areas:

1) modifications to the building shel1,2) use of more efficient HVAC equipment, and 3) incorporation of effective control strategies. Each of these areas is discussed below, to indicate how the heating, ventilation, and cooling end uses can be affected.

The thermal integrity of the building shell (roofs, walls, windows, doors, and floors) can be improved by reducing the themal conductance (U-value). Such reductions will decrease space heating energy requirements and affect space cooling requirements. If the shell has low themal integrity and internal heat gains are small, then space cooling requirements will decrease with thernal integrity improvements. However, if the shell has high thermal integrity and the internal gains are high, thermal integrity improvements may increase space cooling requirements. This is because the internal gains

are "bottled-up" within the shell and more mechanical cooling will be needed to remove them as conductance through the shell is reduced.

Consequently, the optimal levels of shell thermal integrity are a complex function of space heating and cooling system efficiencies, internal gains, ventilation levels, and building microciimate. The ASEAM model does take each of these factors into account, so it can be very useful for site-specific optimization. For the simplified analysis method, the model is run for 11 different thermal integrity energy conservation measures. These are the 
addition of R-11, R-19, and R-30 wall insulation; R-11, R-19, R-30, R-38, and $R-49$ roof insulation; and double, triple, and tinted window glazing. Review of the results confirms that diminishing returns set in as thermal integrity is improved; j.e., doubling the insulation values results in less than double the energy savings. The costs and savings of these measures have been calculated on an incremental basis so as to determine the optimal levels of thermal integrity for each climate and prototype configuration.

The capital costs of most thermal integrity improvements are substantially higher for retrofits than for new construction. For example, the cost of additional wall insulation for a building yet to be constructed is predominantly the cost of the materials, whereas for a retrofit it may be necessary to refinish the exterior or interior walls once the insulation is installed. In many cases the costs are prohibitive, or physical problems cannot be overcome.

Another type of shell improvement is the reduction of infiltration of outside air. In many buildings, air will leak through the wall joints, window frames, doors, and other penetrations. However in the case of the prototype dining hall, the building mechanical systems maintain a higher pressure indoors than outdoors, so at most times infiltration is minimal. With proper balancing, it would be expected that the kitchen would be negatively pressured relative to the dining areas, so that kitchen odors and heat are vented through exhaust fans rather than moving into the dining areas. In such a scenario, some infiltration to the kitchen from the outside would be expected, so attention to the "tightness" of the exterior walls would result in energy savings. However, because such measures are difficult to specify and measure, no attempt to quantify infiltration reductions has been made.

The second generic group of energy conservation measures associated with HVAC equipment is to increase the efficiency of specific components. These components include boilers, furnaces, chillers, fans, pumps, heat exchangers, pipes, ducts, and diffusers. The types and configuration of this equipment are dependent on the type of system, fuel sources, and building loads to be met. A detailed discussion of all the configurations and options for energy efficiency improvements of the HVAC system is beyond the scope of this report. 
However, general areas for improvement are described below, and specific conservation measures applicable to the prototype characteristics are described in some detail.

The simple analysis method considers two HVAC system efficiency improvements. One is application of a more efficient chiller to satisfy the air conditioning needs. The coefficient of performance of this device was altered from a value of 1.9 determined by calibration of the base case model to a value of 2.5 that is more representative of modern efficient equipment. The other measure simulates the effect of using a variable air volume (VAV) HVAC system in place of the constant volume system in the prototype. Sitespecific savings can be examined using the ASEAM model, once it is modified to reflect the actual system characteristics for the facility under study.

Unitary boilers or furnaces may be used to provide space heating and/or domestic water heating. If these devices are fossil-fueled, the combustion efficiencies should be tested periodically and the air/fuel ratios adjusted as appropriate. Efficiencies should be above $70 \%$ for well maintained equipment, resulting in less than $30 \%$ of the heat going up the flue or radiated within the mechanical room. Heat may be recovered from the flue using a heat exchanger to preheat domestic hot water or to preheat combustion air.

Chillers or packaged vapor-compression air-conditioning units are used to provide space cooling. The energy efficiency of these devices can be expressed as a coefficient of performance (COP). This coefficient is the ratio of the heat moved by the device over the energy input to the device. Hence, greater COPs correspond to more effective energy conversion and use. The equipment design has a large effect on the COP, as does the operation and maintenance of the equipment. Effective maintenance includes frequently lubricating bearings, replacing belts and filters, and ensuring that the freon charge is maintained and that controls are calibrated.

Another method to reduce space cooling energy requirements is to use economizers. These devices modulate the quantity of outside air introduced to the building according to outside temperature or enthalpy. If cooling is required and outside air temperatures are low, the economizer dampers open to 
admit $100 \%$ outside air to provide "free" cooling. The dampers can also be controlled by an enthalpy sensor, which also considers the water content or humidity of the outside air. Although enthalpy economizers offer better efficiency, they are more expensive and difficult to calibrate and maintain.

Evaporative precoolers can also be attached to the air conditioning units to precool the air passing over the refrigeration condenser coils. The coils are able to give off more heat, thereby increasing the cooling capacity and reducing compressor run times. Evaporative precoolers cost approximately $\$ 1000$ and have payback periods of approximately 2 to 5 years depending upon climate and cooling load.

Two types of energy efficiency features for exhaust hoods should be considered--makeup air hoods and heat recovery hoods. The makeup air hoods provide outdoor air that moves across the underlying equipment and is subsequently exhausted. In this way, the need for heated or cooled air is reduced, thereby lowering the energy consumption for space heating and cooling. As the name implies, heat-recovery hoods transfer heat from the exhaust air to preheat the incoming air. Special provisions to remove grease accumulations from the heat exchanger coils must be incorporated to preclude fire risks or clogging of the exhaust ducts. In most applications, the makeup air hoods are more cost-effective and easier to maintain than the heat-recovery hoods.

The third area of HVAC conservation opportunities is equipment control. Set-back or "smart" thermostats, energy management control systems, and discriminator controls are examples of such opportunities. Set-back thermostats automatically reduce the thermostat settings during unoccupied periods to reduce heat losses through the building shell. Although these devices save energy, they can increase peak electrical demands when the building temperatures are increased. Hence, be sure to consider this effect if heating is provided electrically and demand charges are significant. More advanced "smart" thermostats are now available that determine the optimal time to turn the thermostat up to meet the interior temperature requirements. This time is dependent upon the outside and inside air temperatures, as we 11 as the time that the building must be warmed up. 
Discriminator controls are used by dual duct distribution systems to reset the deck temperatures for heating and cooling equipment. They sense the temperatures in each zone and determine the temperature of hot and cold ducts necessary to meet the loads of the hottest and coldest zones. Then, the heating and cooling coil temperatures are reset to meet this requirement. Energy savings result by minimizing the mixing of hot and cold air to provide temperature control for the intermediate zones.

Energy management control systems offer the features described above, as well as other features tailored to the specific equipment configurations. These systems typically measure numerous space conditions, consumption levels, equipment status, and building microclimate to automatically control the HVAC systems. Key concepts to keep in mind when evaluating these systems are simplicity and feedback diagnostics. In general, simple systems are more reliable and easier to maintain. More complex systems can offer greater energy efficiency; however, good feedback diagnostics are essential to ensure that the system is operating properly or to specify what maintenance may be required. Many complex applications do not operate properly because of unknown failures or complete overrides by maintenance staft not able to effect a correction or modification. 


\subsection{ENERGY SAVINGS SENSITIVITY ANALYSIS}

This section discusses the analysis for many of the conservation opportunities described in Section 4. The effects of the energy conservation measures on both heating and electrical requirements are described in detail for the cool climate area. The impacts on total energy requirements, assuming an all electric dining hall, are then compared among the four climate types: hot, warm, cool, and cold. This will reveal how conservation measures affect heating and electrical requirements and how these, in turn, affect the performance of conservation measures in a given climate.

The energy conservation measures have been separated into load reduction measures and systen efficiency improvements. Load reduction measures are those energy conservation opportunities that directly affect the heating, cooling, and non-HVAC electrical loads. System efficiency improvements are conservation measures associated with the equipment that is used to meet the loads of the building, such as the heating and air conditioning systems. These measures are distinguished for two reasons: 1) the efficiency of the heating and cooling systems can affect the overall savings of load reduction strategies, and 2) the size of the load can affect the savings of system efficiency improvements.

\subsection{LOAD REDUCTION MEASURES}

Twenty-two distinct load reduction conservation measures have been simulated for each of the four climate types. These measures fall into six categories: 1) window treatments, 2) roof insulation, 3) wall insulation, 4) lighting efficiency, 5) refrigeration efficiency, and 6) kitchen equipment efficiency. Figure 5.1 displays the change in the base case energy consumption induced in the heating and electrical requirements of the prototype dining hall for the load reduction measures.

\subsubsection{Window Treatments}

Three window treatments are considered:

- wtriple - triple glazing

- wdouble - double glazing

- windcoeff - tinting windows to reduce the shading coefficient to 0.5 . 


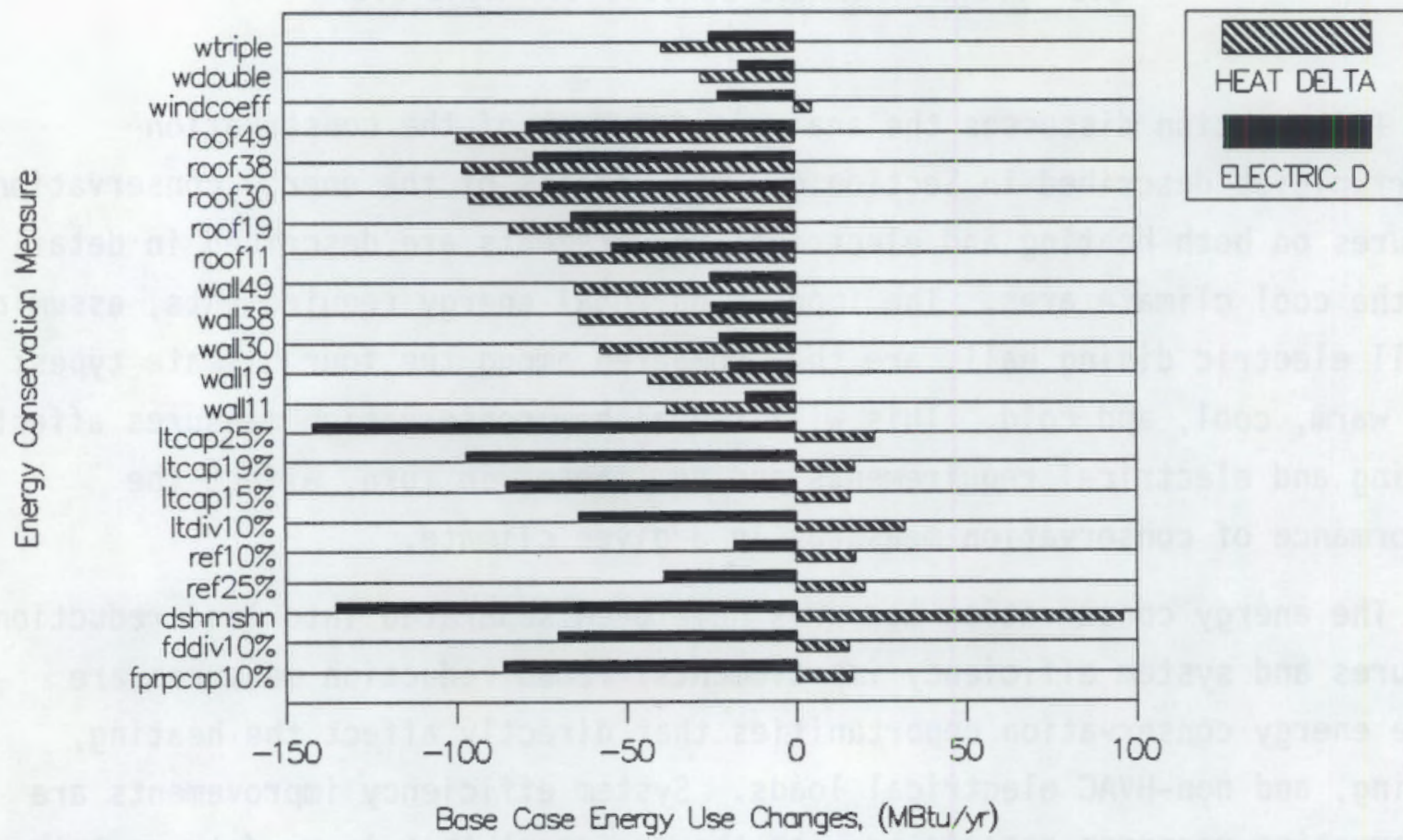

FIGURE 5.1. Energy Use Changes for USAF Dining Hall Load Reduction Measures

As shown in Figure 5.1, additional glazings reduce both heating and electrical air-conditioning requirements, while the tinting significantly reduces

electrical requirements and slightly increases heating energy needs. These effects would be greater if the dining hall had more glazing. For new construction, glazing should be concentrated on the south and east facades, with appropriate overhangs and fins to minimize air conditioning loads and maximize useful solar gains.

\subsubsection{Roof Insulation}

The effect of five levels of roof insulation are indicated in Figure 5.1. These levels range from $R-11$ to $R-49$. Both heating and electrical requirements are reduced, and the diminishing returns of additional insulation are apparent by examining the incremental savings as the level is increased. The savings due to adding R-11 are fully $70 \%$ of the savings achieved by a more than four-fold increase to R-49 insulation. This has important consequences when the cost-effectiveness is evaluated. 


\subsubsection{Wall Insulation}

Five levels of wall insulation are indicated in Figure 5.1, from adding R-11 to R-49. Energy savings are smaller than the comparable roof insulation effects, particularly for electrical demands. This is because the wall area is less than that of the roof, and the interior dishwashing area is not airconditioned but heated. Heating needs for this interior area is reduced as roof insulation is added; however, adding wall insulation has no effect on this area.

\subsubsection{Lighting Efficiency Improvements}

The results of four lighting efficiency improvements are indicated in Figure 5.1. These are:

- Itcap25\% - 25\% capacity reduction (electronic ballasts and high efficiency fluorescent lamps)

- Itcap $19 \%$ - $19 \%$ capacity reduction (use of parabolic reflectors)

- Itcap15\% - 15\% lighting reduction (high efficiency fluorescent lamps)

- Itdiv10\% - reduction of lighting diversity by $10 \%$ (motion detectors to turn of lights during unoccupied periods).

These measures save significant amounts of electricity. However, they also significantly increase heating needs, because about $40 \%$ of the heat of the lights is useful to offset heating loads. This percentage is higher for the diversity reduction, because these savings occur predominantly during unoccupied periods when heating is more likely to be required.

\subsubsection{Refrigeration Efficiency Improvements}

Two levels of refrigeration efficiency improvements were simulated. These are:

- ref $10 \%$ - reduction of refrigeration loads by $10 \%$ due the installation of strip curtains over the walk-in refrigerators

- ref25\% - reduction of refrigeration loads by $25 \%$ from the use of watercooled condensers. 
These measures will increase heating loads only if the condensers are located inside the conditioned space. With external condensers, heating loads from the ref $10 \%$ alternative will actually be reduced slightly due to the reduction of cold air entering the heated space.

\subsubsection{Kitchen Equipment Efficiency Improvements}

Three kitchen equipment efficiency improvement levels were simulated:

- dshmshn - use of a low-temperature dishmachine

- fddiv10\% - reduction of food preparation equipment diversity factors by $10 \%$ by better operation and maintenance

- fprpcap $10 \%$ - reduction of food preparation equipment capacity by a $10 \%$ improvement in appliance efficiency.

These measures provide large reductions in electrical demands and significantly increase heating demands. This is particularly true for the dishmachine, which is located in a highly ventilated area. Reduced waste heat from a lowtemperature machine must be made up by the heating and ventilating unit to keep the dishwashing area warm.

\subsection{SYSTEM ENERGY EFFICIENCY IMPROVEMENTS}

The results of eight simulated improvenents to system efficiency levels are indicated in Figure 5.2. These are:

- temp=55 - setback of heating season themostat settings to $55^{\circ} \mathrm{F}$ during the unoccupied periods

- htpumphw - use of a heat pump water heater

- kitchcfm - $50 \%$ reduction of exhaust makeup air to the kitchen by using heat recovery or make-up air type exhaust hoods

- wshp - use of a water source heat pump to provide space heating

- vav - use of a variable air volume heating and cooling system

- aahp - use of air-to-air heat pumps to provide space heating

- economizer - installation of an economizer cycle to reduce space cooling energy consumption 


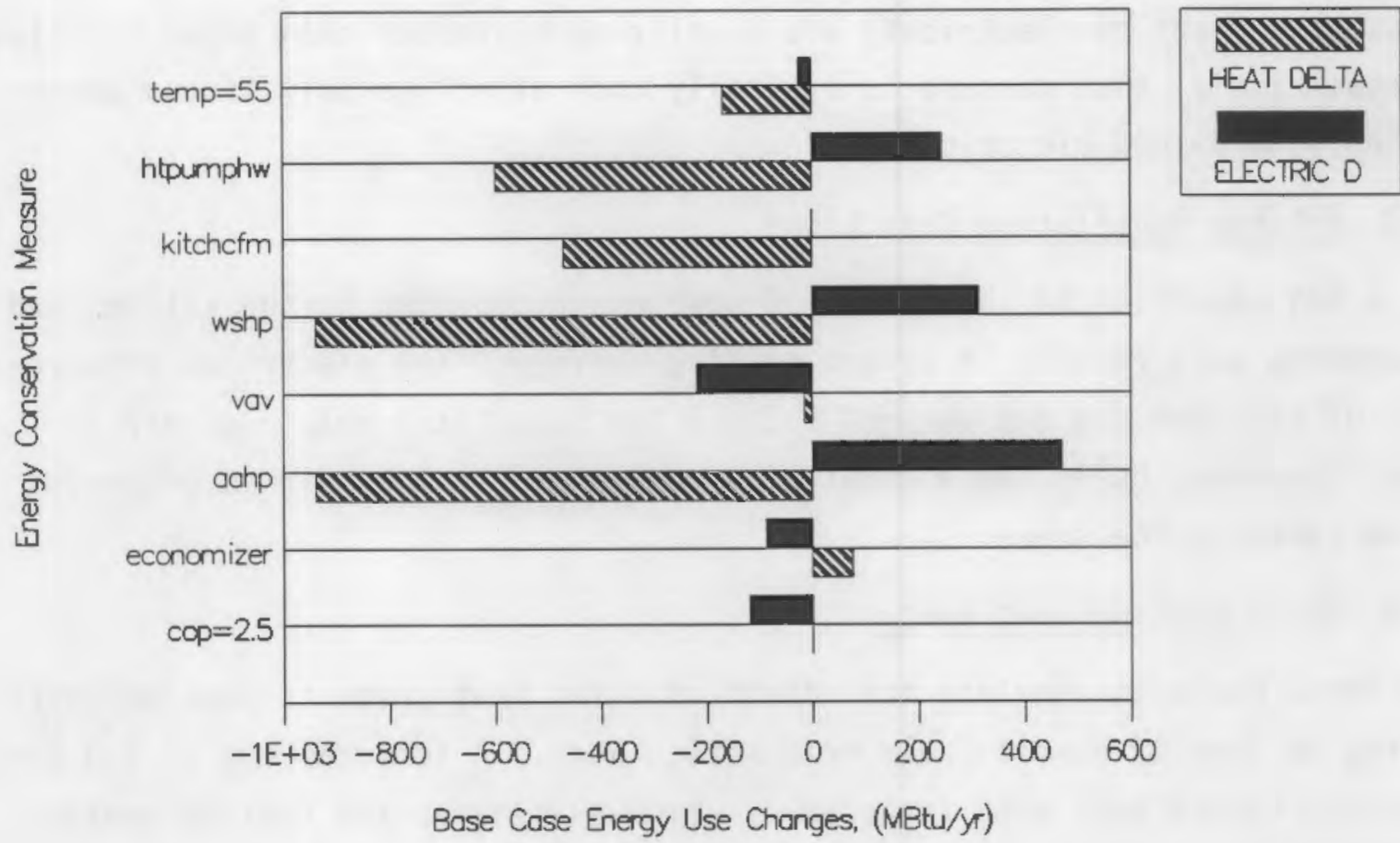

FIGURE 5.2. Annual Energy Use Changes for USAF Dining Hall for System Efficiency Improvements

- $c o p=2.5$ - use of efficient air conditioning systems rather the 1.9 COP unit in the prototype.

Each is discussed in the following paragraphs.

\subsubsection{Set-Back Thermostats}

The thermostat set-back strategy reduces both heating and air conditioning needs. The slight reduction in air conditioning requirements is caused by the effect of cooling off the building mass at night. This cooled mass will absorb some of the heat that would otherwise be removed by the air conditioning systems.

\subsubsection{Hot Water Heat Pumps}

Using an electric heat pump to provide for domestic hot water requirements reduces the demands for district heat, at the expense of significant increases in electrical requirements. Energy savings result from the fact that the 
heat pump is over twice as efficient as the use of district heat. However, because the costs of electricity are usually much greater than those for steam or fossil fuels, this measure is typically cost-effective only if the water heating is provided electrically.

\subsubsection{Kitchen Ventilation Reductions}

A $50 \%$ reduction in the volume of makeup air provided to the kitchen and dishwashing area results in direct heating savings. The electrical requirements of the fans are not changed because the same total volume of air is moved. However, using these strategies, only half as much air is preheated before entering the space.

\subsubsection{Space Heating Heat Pumps}

These measures simulate the effect of using heat pumps to provide space heating in lieu of fossil fuels or district heat. A seasonal COP of 3.0 for the water source heat pump is assumed, which eliminates the heating energy requirements and increases electrical needs by $33 \%$ of this value. The airto-air heat pump has an assumed seasonal COP of 2.0, increasing electrical needs by $50 \%$ of the base case heating requirements. In light of the differential heat and electric fuel costs, these measures are usually costeffective only if the heating is provided electrically.

\subsubsection{Variable Air Volume Heating and Cooling System}

This energy conservation measure is applicable to new construction, where an alternative to the three system types in the prototype dining hall is installed. This system modulates the volume of heated and cooled air provided to the various dining hall zones in relation to the heating and cooling zone loads. In this way, fan energy requirements are significantly reduced. Heating increases slightly because of the reduced waste heat of the fans to offset space heating requirements.

\subsubsection{Economizer Cycles}

The use of an economizer to introduce outside air when it can be used to effectively cool the building reduces electrical needs due to the savings in air conditioning energy. If properly adjusted and maintained the measure 
should not affect heating energy requirements. However, heating often increases somewhat due to equipment failures.

\subsubsection{Improving the Air Conditioner COP}

This measure simulates the savings obtained by increasing the seasonal COP of the air conditioner from 1.9 to 2.5. The value of 1.9 was obtained by calibrating the measurements from the prototype dining hall. The 2.5 value is more typical of performance to be expected, according to equipment manufacturers. This measure will decrease electrical requirements without affecting heating energy needs.

\subsection{THE IMPACT OF CLIMATE TYPES ON ENERGY SAVINGS}

This section describes how the interactions identified in Sections 5.1 and 5.2 affect the energy savings of the measures in various climate regimes. The performance of each energy conservation measure described above was estimated in each of four climate types. Tampa, Florida, was selected to represent hot climates; Atlanta, Georgia, warm climates; Dayton, Ohio, cool climates; and Great Falls, Montana, cold climates.

Figure 5.3 depicts the relative energy savings for each of 22 load reduction measures in each of the four climate regimes for an all-electric building. Because the efficiency of the heating system affects the performance of most conservation measures, the results would be somewhat different if fossil fuels or district heat were used. The relative energy use impacts are similar, and the simple analysis method accounts for this affect. This discussion is intended to give the reader an appreciation for the types of conservation measures most affected by climate change.

With the exception of the use of strip curtains on refrigerator doors in cold climates, all the measures result in energy savings. If the refrigeration condensers are located outdoors, even this measure will result in energy savings. On a percentage of savings basis, window tinting, refrigeration system improvements, and the use of low-temperature dishmachines is most affected by climate change. Insulation and lighting measures appear to be less sensitive to climate variation. 


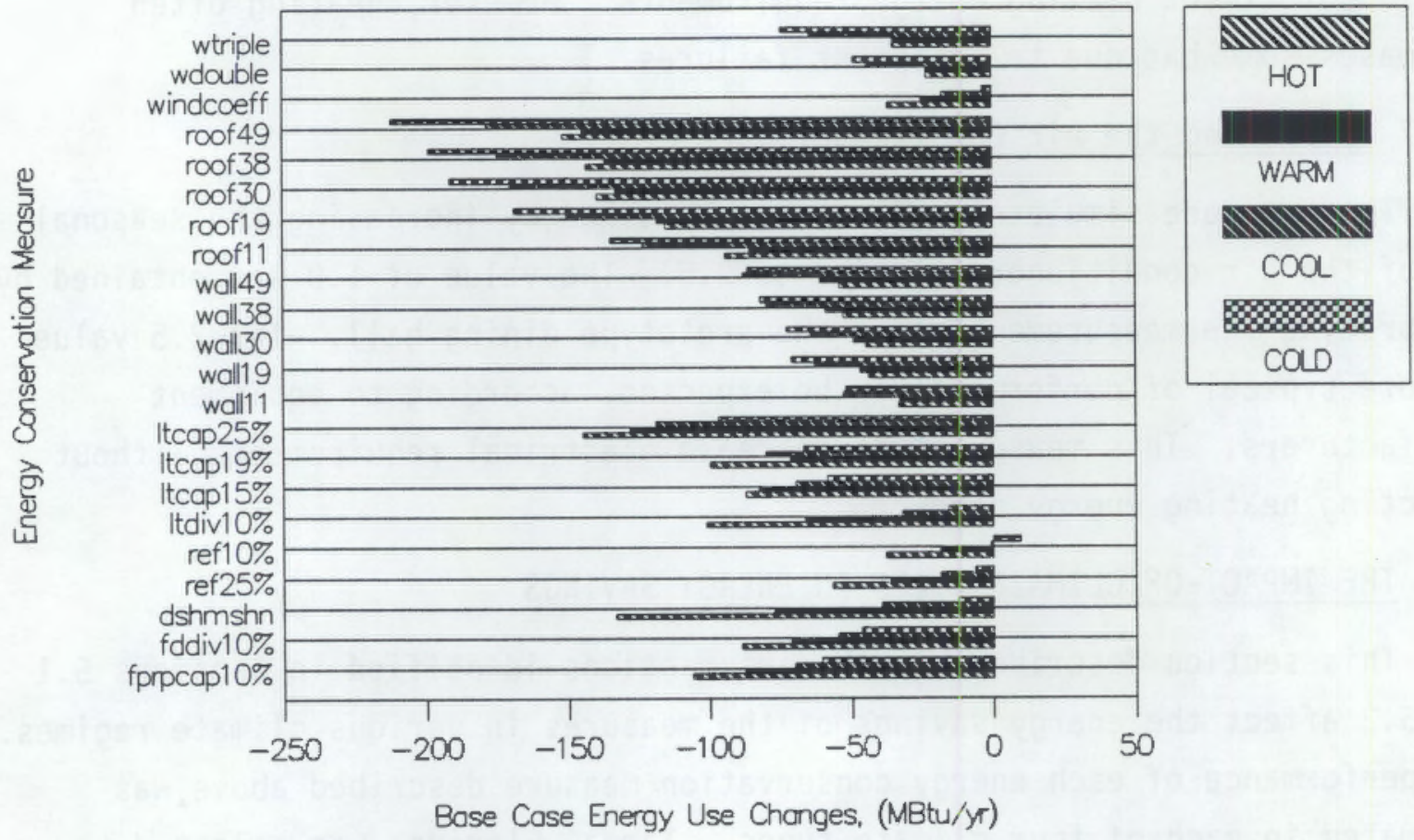

FIGURE 5.3. Impact of Load Reduction Measures on Total Energy Use in an All-Electric Building

It is interesting to note that the measures affecting the building envelope (walls, roofs, and windows) perform best in colder climates, while the measures affecting the efficiency of internal equipment perform best in the warmer climates. This stems primarily from the fact that the energy "wasted" by inefficient appliances is more effectively used to offset space heating in the coldest climates, resulting in lower net savings.

The impact of eight system efficiency improvements is depicted in Figure 5.4. The variable air volume system and economizer cooling are relatively insensitive to climate change, with the exception of the cool climate where the economizer savings are small. The other measures, with the exception of the more efficient air conditioners, perform significantly better in colder climates. 


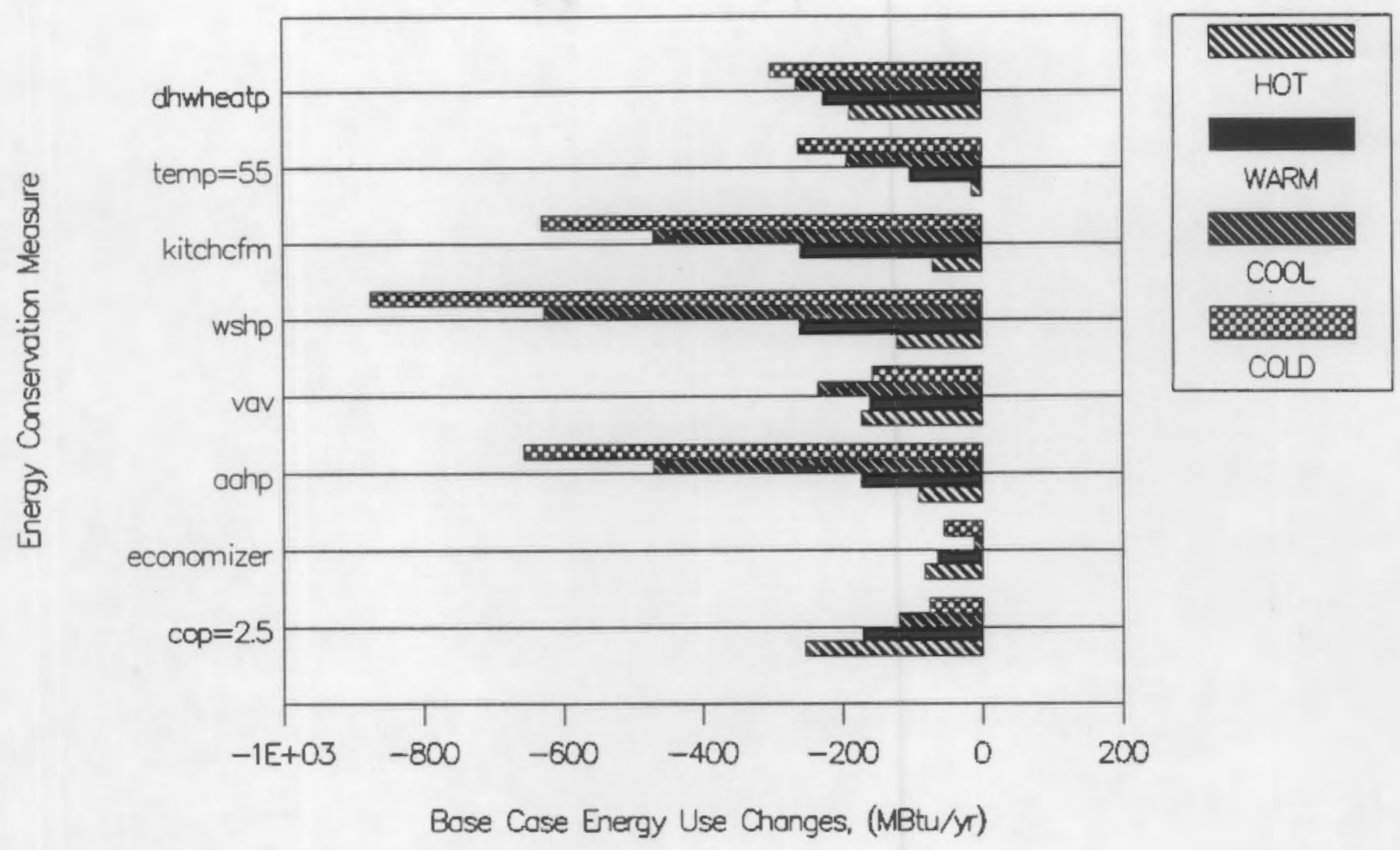

FIGURE 5.4. Impact of System Efficiency Improvement on Total Energy Use in an All-Electric Building 


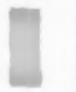

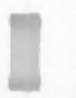

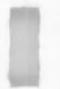

]

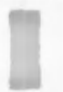

II

】

I

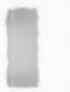

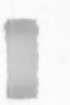

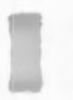

]

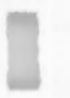

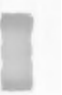

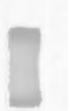

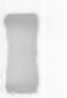

.

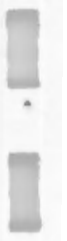<smiles>C1=CCCCC1</smiles> 


\subsection{A SIMPLE METHOD TO DETERMINE ENERGY CONSERVATION}

MEASURE COST-EFFECTIVENESS

A principal goal of this study was to develop a simple method to determine the cost-effectiveness of energy conservation measures applicable to USAF dining halls. This effort was complicated by the dependency of energy savings on prototype configuration, climate, fuel costs, and escalation rates. To incorporate these sensitivities into the analysis, a set of tables was developed. Each table refers to a particular climate type and lists the energy savings estimates for specific conservation measures in the prototype dining hall.

This section describes the simple method for determining conservation measure cost-effectiveness and the assumptions upon which it is predicated. The method provides quick estimates of conservation measure cost-effectiveness and explicitly accounts for the major impacts of climate severity and energy costs. For more detailed and accurate estimates, the ASEAM 2.1 model should be calibrated to the specific building characteristics and conservation measure costs.

The first step of the method is to determine the appropriate climate type for the analysis. Table 3.2 and Figure 3.6 indicated the climate type for each of 46 weather locations. The site geographically closest to the building location generally should be selected. If several sites are close, it may be useful to compare typical weather-year data for the specific location with the weather summaries provided in the ASEAM documentation to select the best climate station. In most cases, however, these stations will be in the same climate type.

The ASEAM 2.1 model was run to provide estimates of the electrical and heat energy savings associated with each energy conservation measure in each of four climate types. Energy for heating is distinguished from nonheat electrical consumption, to incorporate both fossil and electrical energy costs into the energy savings calculation. If only electricity is used, then these savings can be combined before the economic analysis is performed. 
The economic analysis is carried out using the appropriate form for the case under study. These forms include the results of the prototype energy analysis and spaces for entering an adjustment factor to account for the appropriate fuel conversion efficiency, fuel costs (FC), and uniform present worth factors (UPW). Multiplying the annual energy savings by the conversion efficiency and the fuel costs results in an estimate of the dollar value of energy savings in the first year. Multiplication of this value by the appropriate uniform present worth factor results in an estimate of the netpresent-value (NPV) of these dollar savings over the expected life of the conservation measure. This calculation adjusts for the $7 \%$ discount rate (or time-value of money) mandated for federal investment relative to the escalation rate of fuel costs for each region of the country. Dividing the net-presentvalue of energy savings by the capital cost of the measure results in an estimate of the savings to investment ratio. According to the FEMP criterion, measures with a savings to investment greater than 1.0 are cost-effective.

If the cost/benefit ratios will be used to prioritize the opportunities, they should all be calculated using the same lifetime. Typically, 20 years is used as a lifetime for comparative purposes. Thus, for measures with useful lives of less than 20 years, such as efficient lights, the discounted replacement costs must be calculated. This procedure is discussed in detail in the Life Cycle Costing Manual for the Federal Energy Management Program (Ruegg 1987), and has been incorporated to develop the capital costs for the prototype conservation measures. This procedure is unnecessary if the intention is only to determine if a particular measure is cost-effective.

Worksheets to carry out the simplified energy analys is procedure for each climate type are presented in Tables 6.1 through 6.4. For each of 28 conservation opportunities, these sheets list the conservation measure description, the estimated useful life of the measure, and the annual energy savings in terms of million BTU/year. Section 6.1 describes how to select the appropriate worksheet and fill out the blanks in order to determine the savings-to-investment ratio (SIR) for each measure.

In order to be cost effective the savings-to-investment ratios must be greater than 1.0. However, since the energy saving of many measures is reduced 
Table 6.1. Cold Climate Simplified Analysis Worksheet

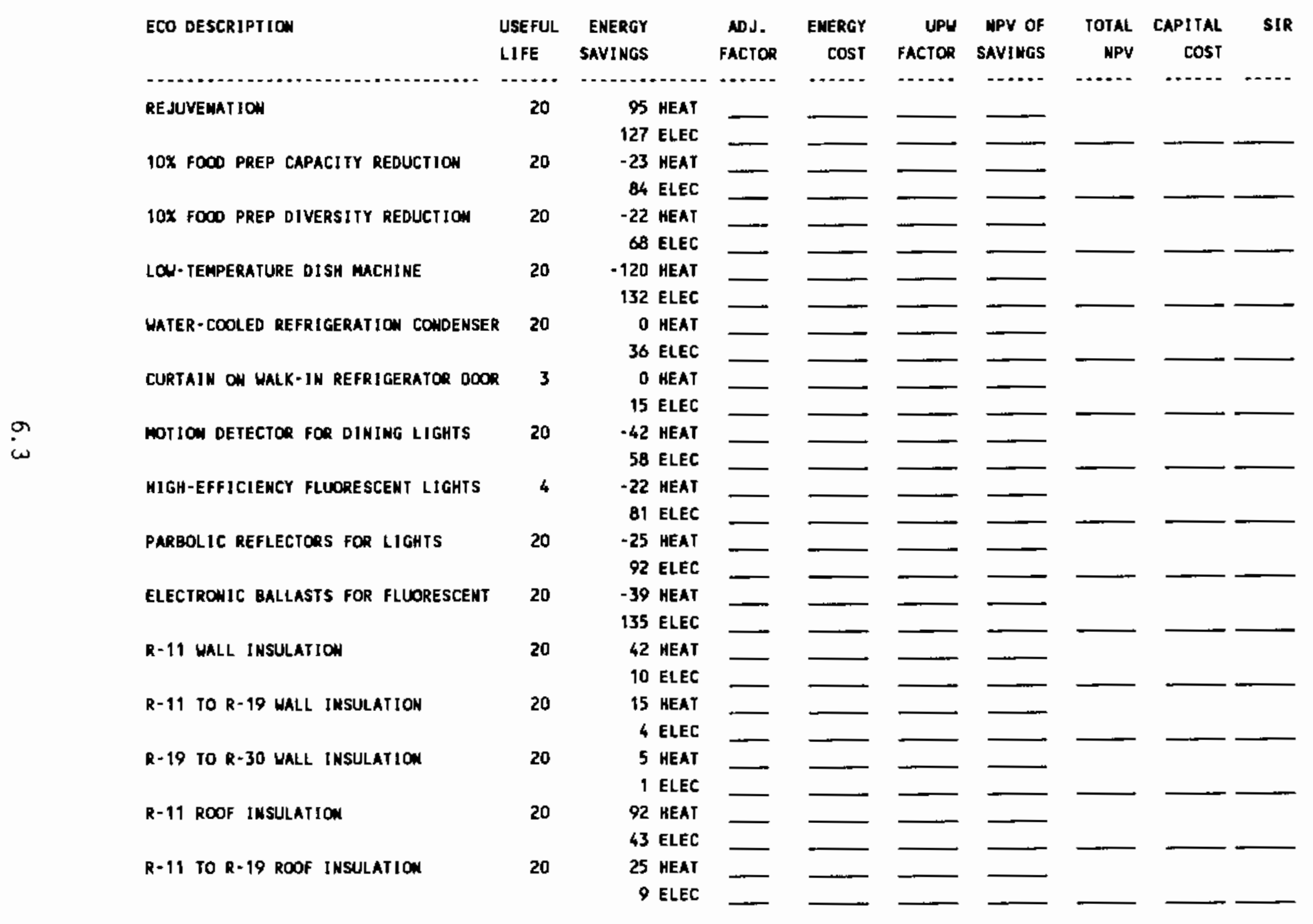


Table 6.1. Cold Climate Simplified Analysis Worksheet (contd.)

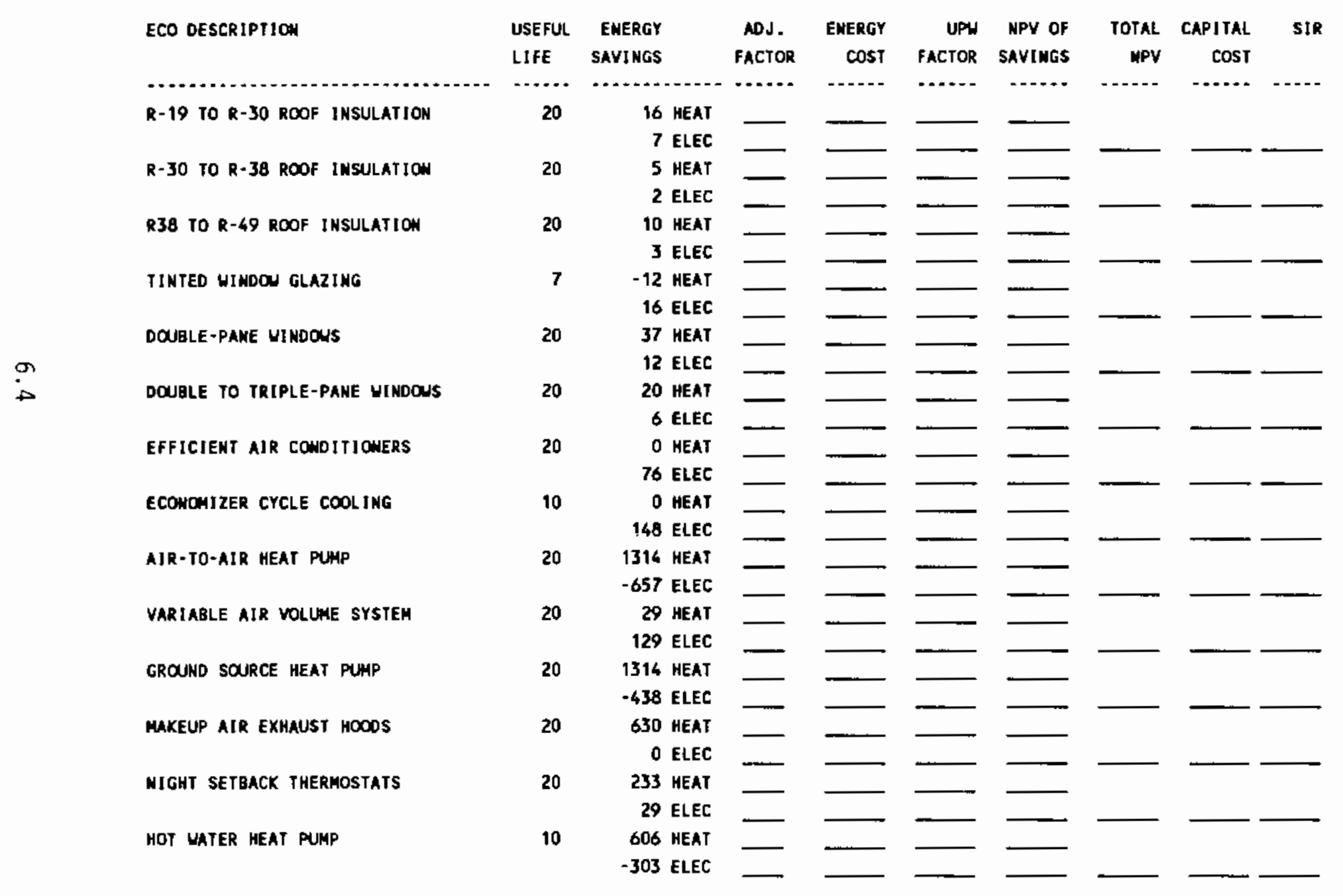


Table 6.2. Cool Climate Simplified Analysis Worksheet

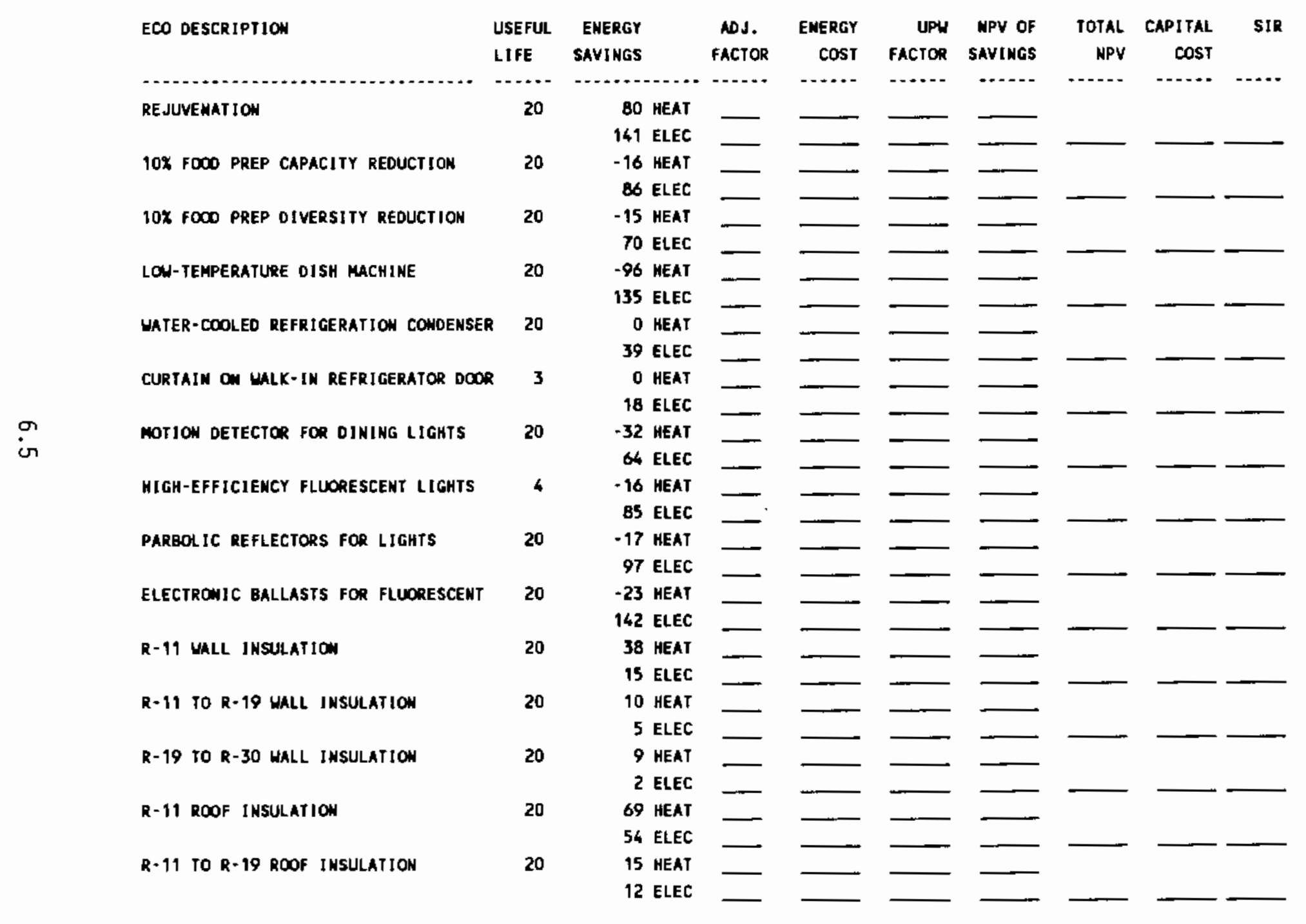


Table 6.2. Cool Climate Simplified Analys is Worksheet (contd.)

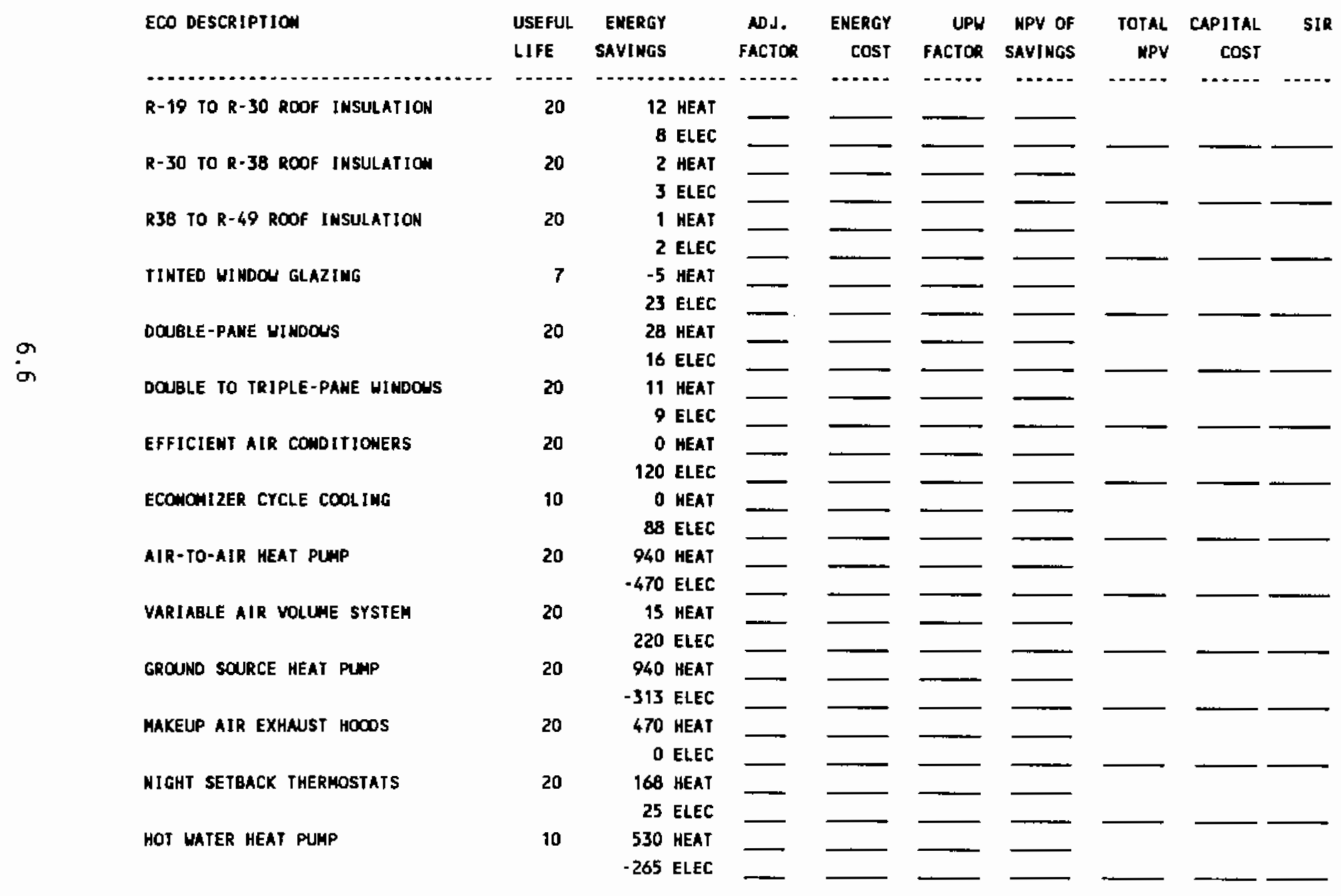


Table 6.3. Warm Climate Simplified Analys is Worksheet

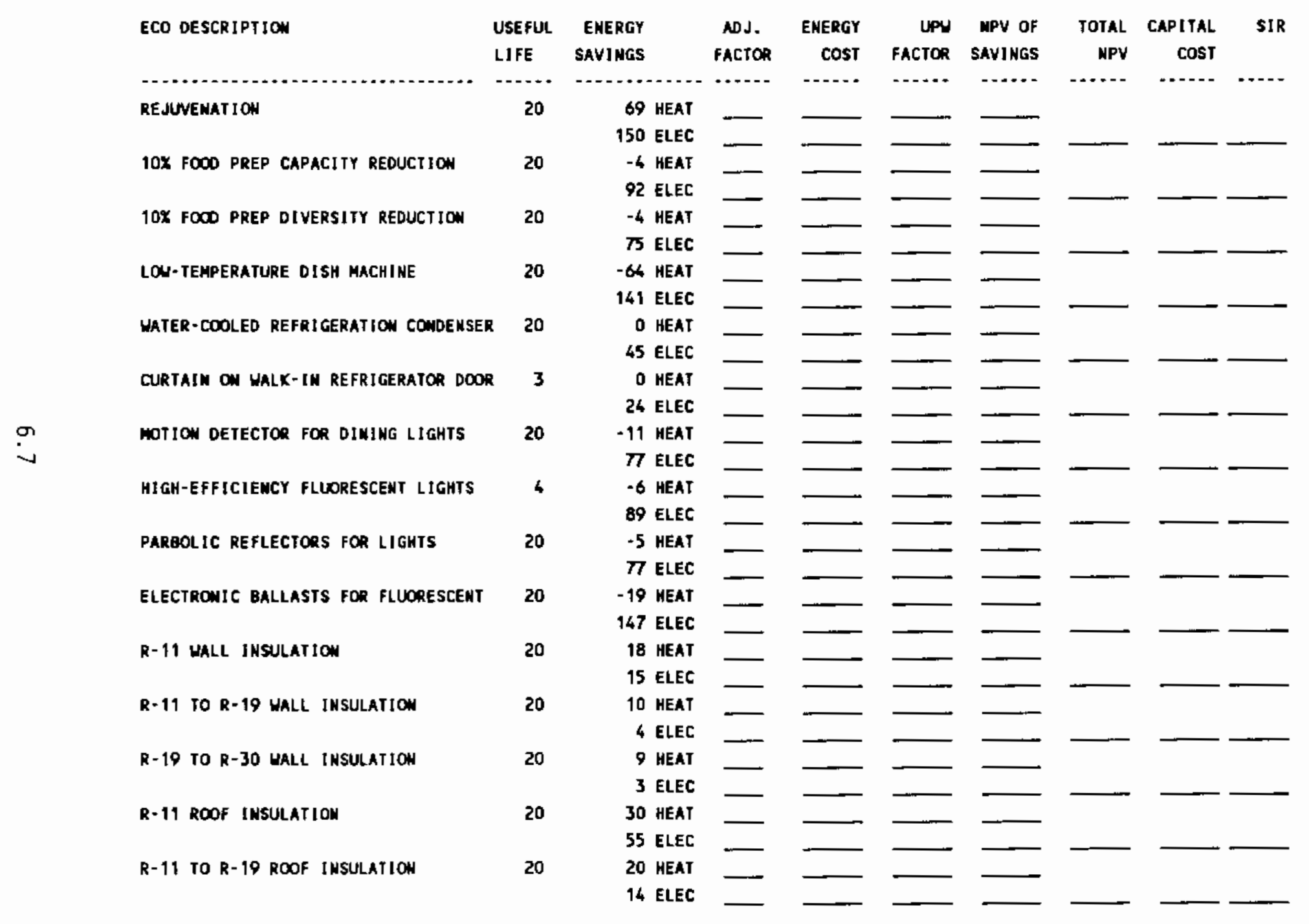


Table 6.3. Warm Cliante Simplified Analysis Worksheet (contd.)

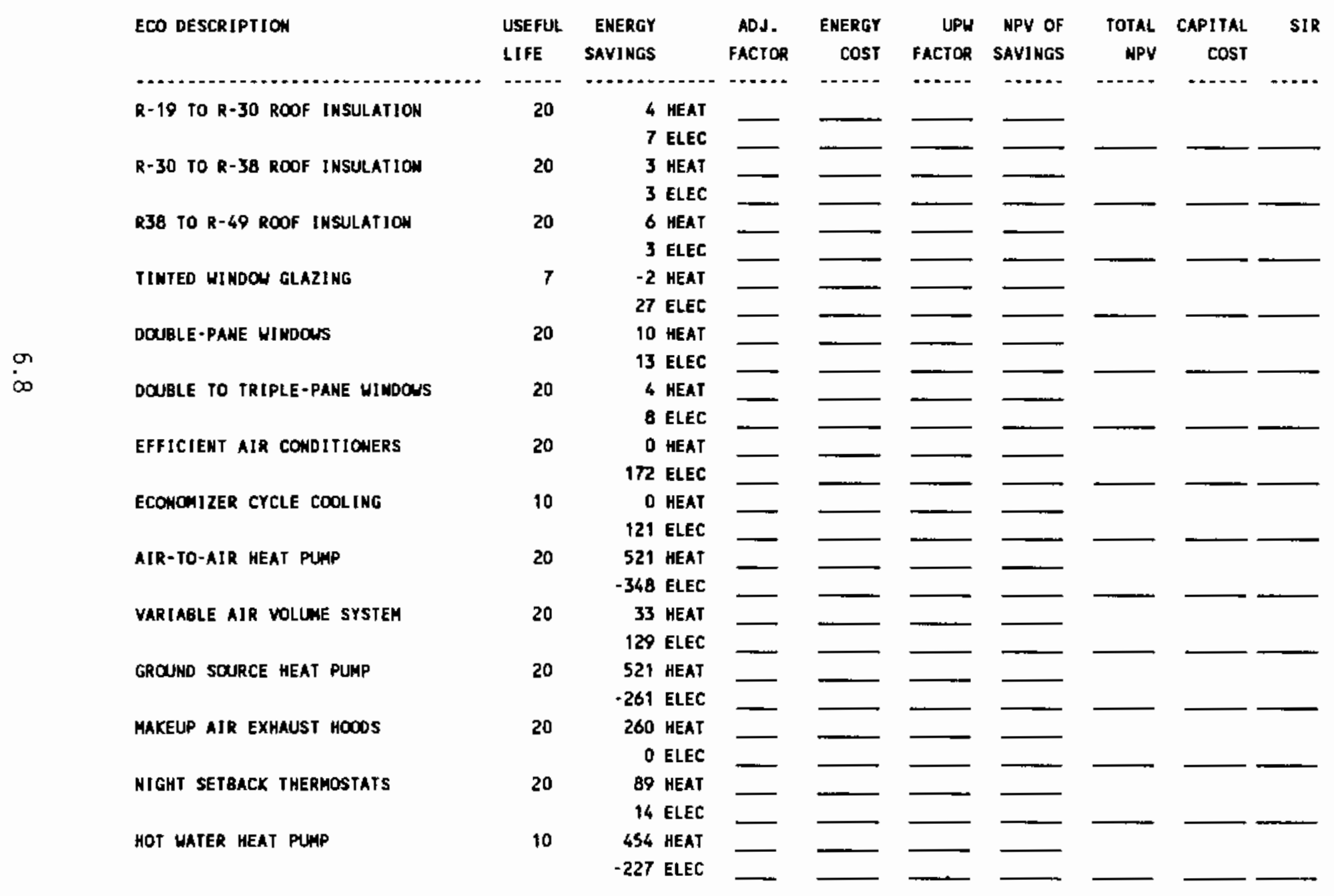


Table 6.4. Hot Climate Simplified Ananlysis Worksheet

\begin{tabular}{|c|c|c|c|c|c|c|c|c|}
\hline ECO DESCRIPTION & $\begin{array}{l}\text { USEFUL } \\
\text { LIFE }\end{array}$ & $\begin{array}{l}\text { EMERGY } \\
\text { SAVINGS }\end{array}$ & $\begin{array}{l}\text { ADJ. } \\
\text { FACTOR }\end{array}$ & $\begin{array}{r}\text { EMERGY } \\
\text { COST }\end{array}$ & $\begin{array}{r}\text { UPH } \\
\text { FACTOR }\end{array}$ & $\begin{array}{l}\text { MPV OF } \\
\text { SAVINGS }\end{array}$ & $\begin{array}{c}\text { TOTAL } \\
\text { MPV }\end{array}$ & $\begin{array}{r}\text { CAPI IAL } \\
\text { COST }\end{array}$ \\
\hline \multirow[t]{2}{*}{ RE JUVENATIOH } & 20 & 52 HEAT & & 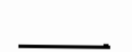 & & & & \\
\hline & & 163 ELEC & - & & & & & \\
\hline \multirow[t]{2}{*}{ TOX FOOD PREP CAPACITY REOUCTIOH } & 20 & 7 MEAT & - & & & - & & \\
\hline & & 99 ELEC & - & & & & & \\
\hline \multirow[t]{2}{*}{ 10X FOOD PREP DIVERSITY REDUCIIOW } & 20 & 7 HEAT & $\ldots$ & & & & & \\
\hline & & 82 ELEC & $\ldots$ & & & & & \\
\hline LOH-TEMPERATURE DISH MCHINE & 20 & - 15 HEAT & - & & & & & \\
\hline \multirow[t]{2}{*}{ WATER-COOLED REFRIGERATION CONDENSER } & 20 & O HEAT & 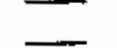 & 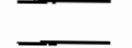 & 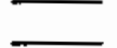 & & & \\
\hline & & 52 ELEC & $\longrightarrow$ & 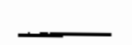 & & 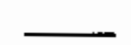 & & \\
\hline \multirow[t]{2}{*}{ CURTAIN OW HALK-IN REFRIGERATOR DOOR } & 3 & O HEAT & — & 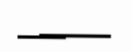 & 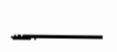 & - & & \\
\hline & & 31 ELEC & $\ldots$ & - & & _ & & \\
\hline \multirow[t]{2}{*}{ MOIION DETECTOR FOR DINING LIGHTS } & 20 & 6 MEAT & — & & & - & & \\
\hline & & 95 ELEC & $\ldots$ & & & & & \\
\hline HIGH-EFFICIENCY FLUORESCENT LIGHTS & 4 & 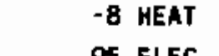 & - & - & & & & \\
\hline \multirow[t]{2}{*}{ PARBOLIC REFLECTORS FOR LIGHTS } & 20 & -8 HEAT & — & 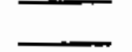 & & & & \\
\hline & & 108 ELEC & $\ldots$ & 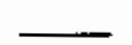 & & & & \\
\hline \multirow[t]{2}{*}{ ELECTRONIC BALLASTS FOR FLUORESCENT } & 20 & -14 HEAT & $\ldots$ & . & 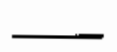 & & & \\
\hline & & 159 ELEC & $\ldots$ & & & 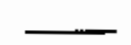 & & \\
\hline \multirow[t]{2}{*}{ R-11 UALL INSULATION } & 20 & 14 HEAT & - & 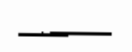 & & & & \\
\hline & & 19 ELEC & — & & & & & \\
\hline R-11 TO R-19 WALL INSULATIOW & 20 & 7 HEAT & $\longrightarrow$ & 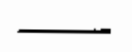 & & & & \\
\hline \multirow{2}{*}{ R-19 TO R-30 UALL IMSULATION } & 20 & 3 HEAT & 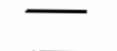 & & & & & \\
\hline & & 5 ELEC & 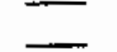 & & & & & \\
\hline \multirow[t]{2}{*}{ R-11 ROOF INSULATION } & 20 & 22 HEAT & — & 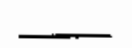 & 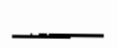 & $\ldots$ & & \\
\hline & & 73 ELEC & - & & & & & \\
\hline R-11 TO R-19 ROOF INSULATION & $<0$ & $\begin{array}{l}3 \text { REAT } \\
17 \text { ELEC }\end{array}$ & $\bar{c}$ & & & & & \\
\hline
\end{tabular}


Table 6.4. Hot Climate Simplified Analysis Worksheet (contd.)

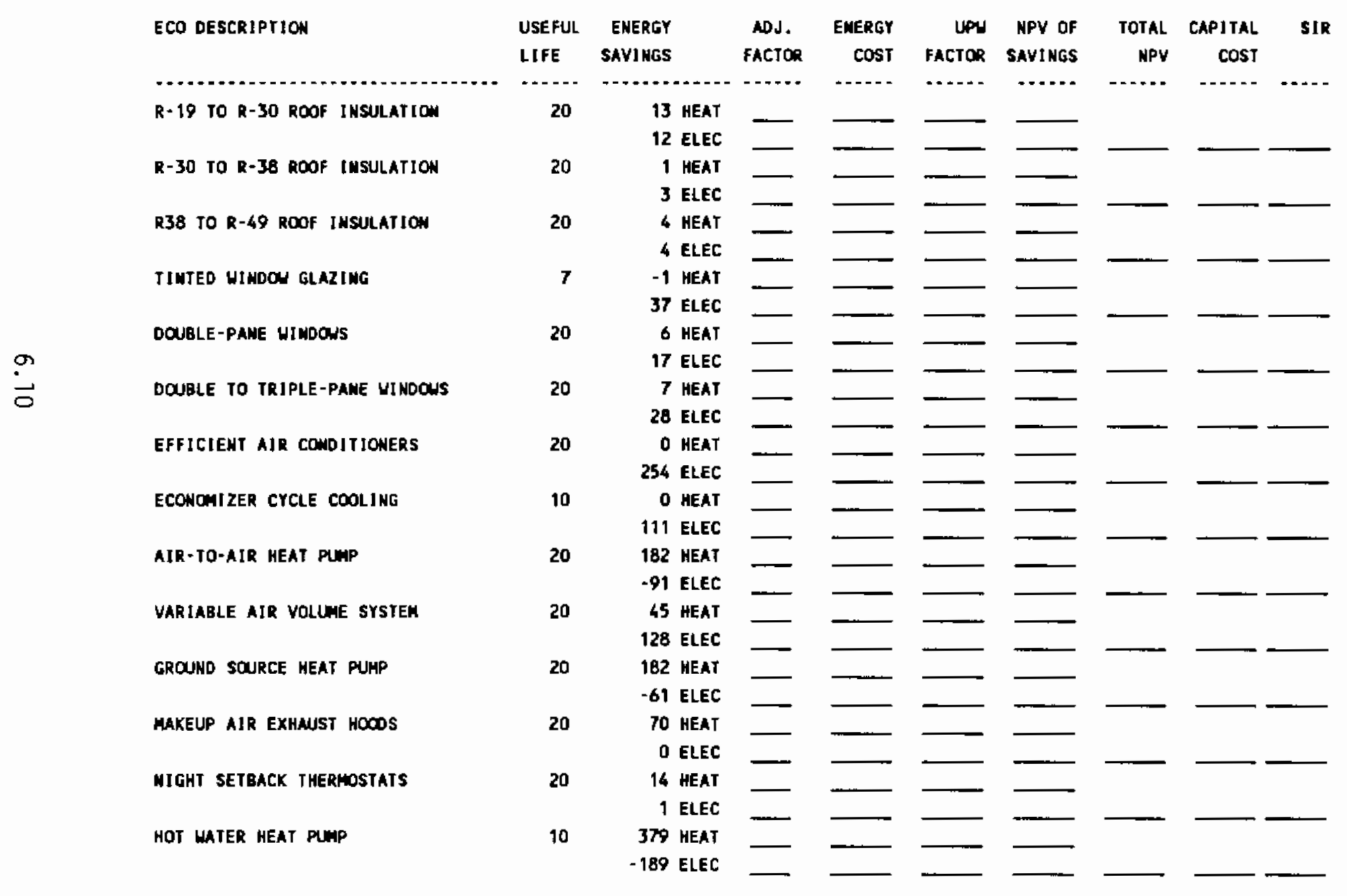


as other measures are implemented, a SIR of greater than 1.3 may be necessary to assure cost-effectiveness.

Another way to use these worksheets is to calculate the net present value of energy savings and compare this to the total capital costs of the measure. So long as the net present value of energy savings exceeds the total capital costs, the measures are cost effective according to the FEMP criteria.

A sample application of these forms is provided below to demonstrate their use, and to develop summary conclusions and recommendations for cost effective energy efficiency improvements.

\subsection{SAMPLE APPLICATIONS OF THE SIMPLE ANALYSIS METHOD}

The results of the energy analysis using fuel costs and escalation rates for DOE Region 3 are shown in Tables 6.5 through 6.8 for an all-electric dining hall, and in Tables 6.9 through 6.12 for a dining hall with district heat. The costs are estimated for application to a new building, and have been properly calculated assuming a common lifetime of 20 years and a discount rate of $7 \%$.

The column titled ADJ. FACTOR is included to account for specific performance adjustments. The most common adjustment will be for the fuel conversion efficiency. The energy savings listed on the forms assume $100 \%$ conversion efficiencies. In most cases the actual efficiency of heating equipment will be considerably lower. For district heat, an efficiency of $50 \%$ may be appropriate to account for the efficiency of the steam plant and distribution system. For standard oil-fired furnaces or boilers, an efficiency of $65 \%$ is often used. For standard natural gas furnaces and boilers, a value of $70 \%$ can be used. If a heat pump is used, an efficiency of $250 \%$ is possible, because only $1 \mathrm{~W}$ of power is needed to provide $2.5 \mathrm{~W}$ of heat. The appropriate adjustment factor is the reciprocal of the efficiency, or $1 / \mathrm{E}$.

A second type of adjustment that may be made relates to the interaction of energy conservation measures. For example, the performance of load reduction measures, such as additional insulation, is dependent upon the 
TABLE 6.5. Sample Analys is for Cold Climate, Region 3 Fuel Costs, Electric Heat, New Building

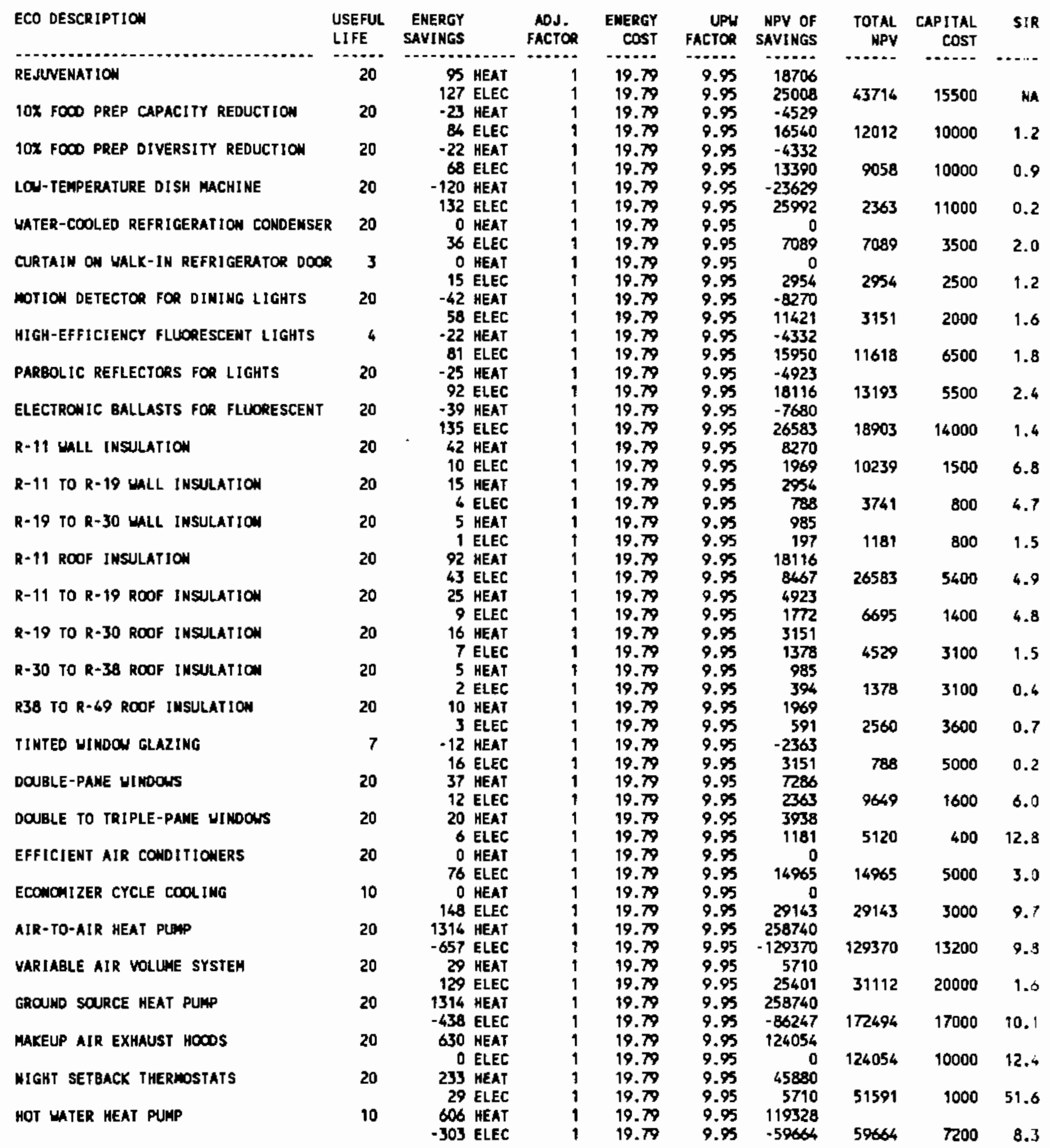


IABLE 6.6. Sample Analysis for Cool Climate, Region 3 Fuel Costs, Electric Heat, New Building

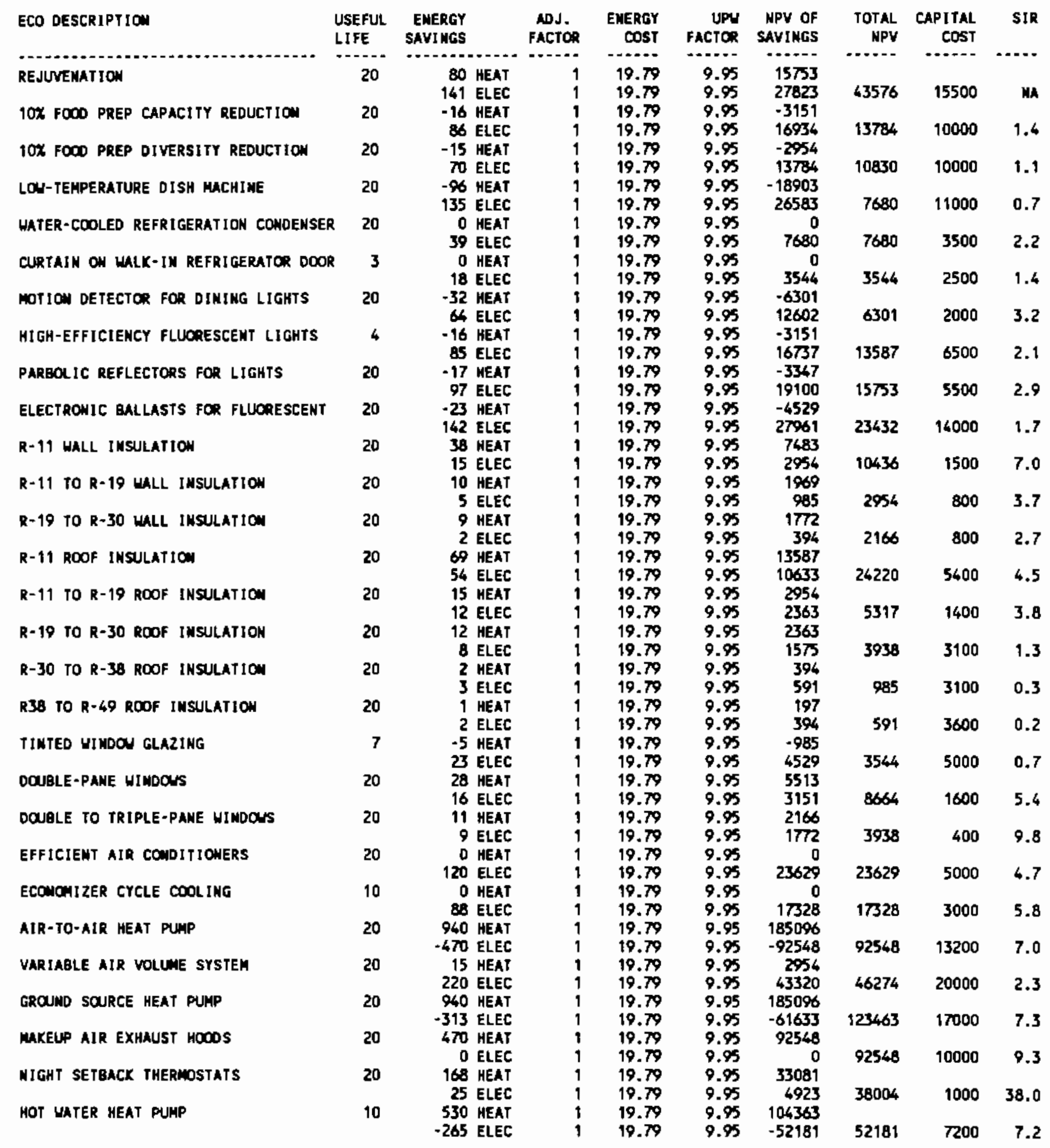


TABLE 6.7. Sample Analys is for Warm Climate, Region 3 Fuel Costs, Electric Heat, New Building

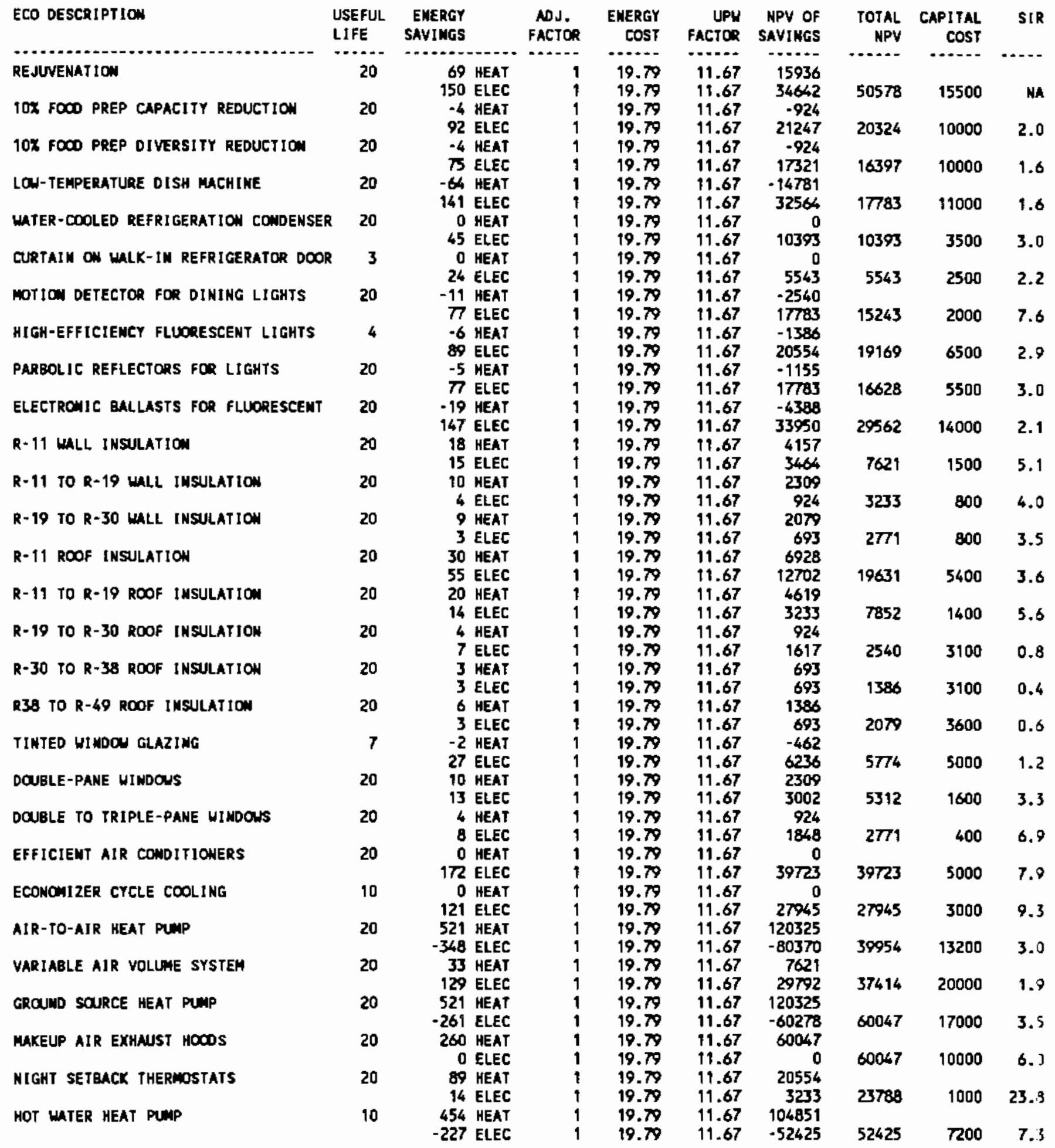


TABLE 6.8. Sample Analys is for Hot Climate, Region 3 Fuel Costs, Electric Heat, New Building

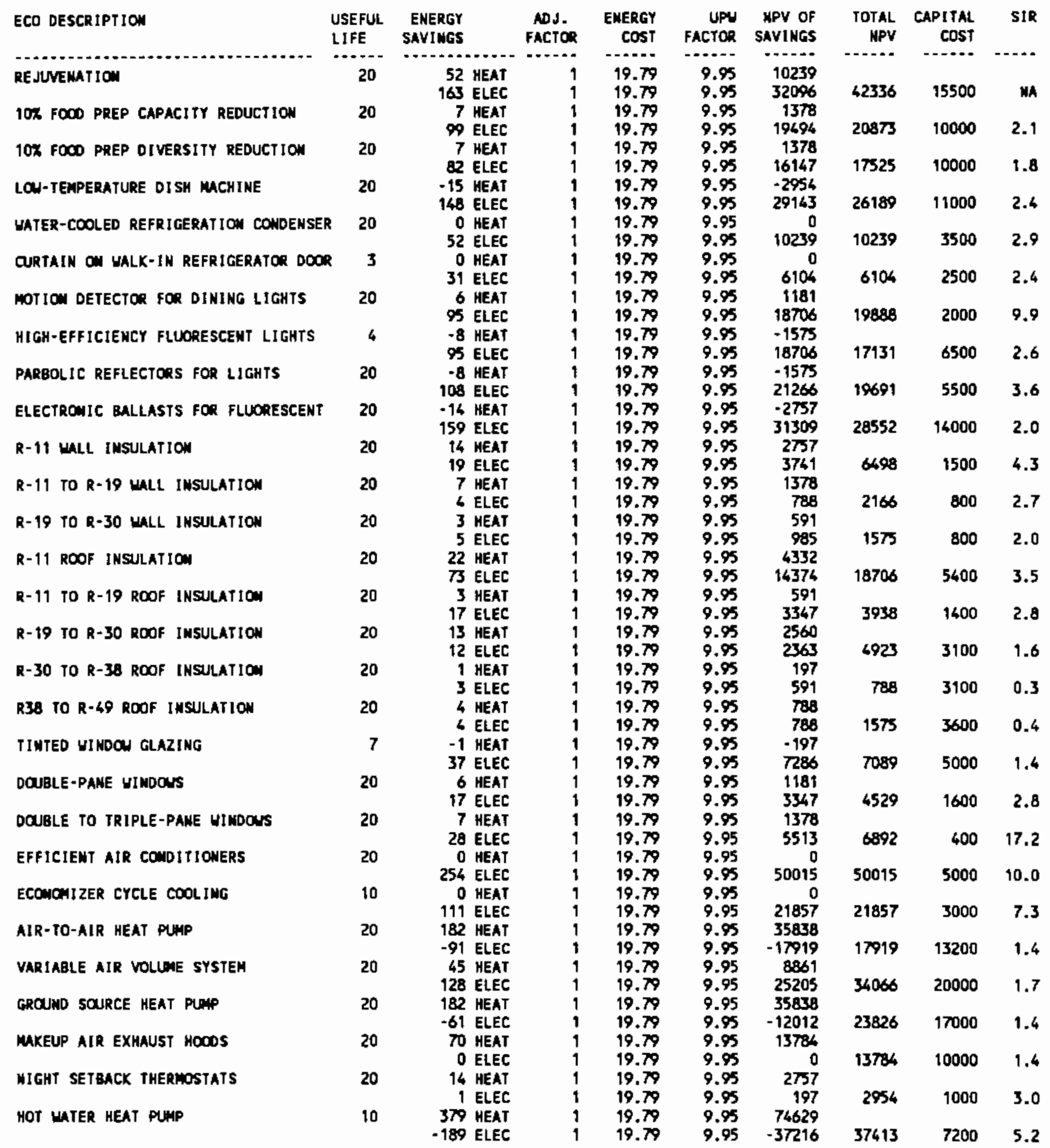


TABLE 6.9. Sample Analysis for Cold Climate, Region 3 Fuel Costs, Steam Heat, New Building

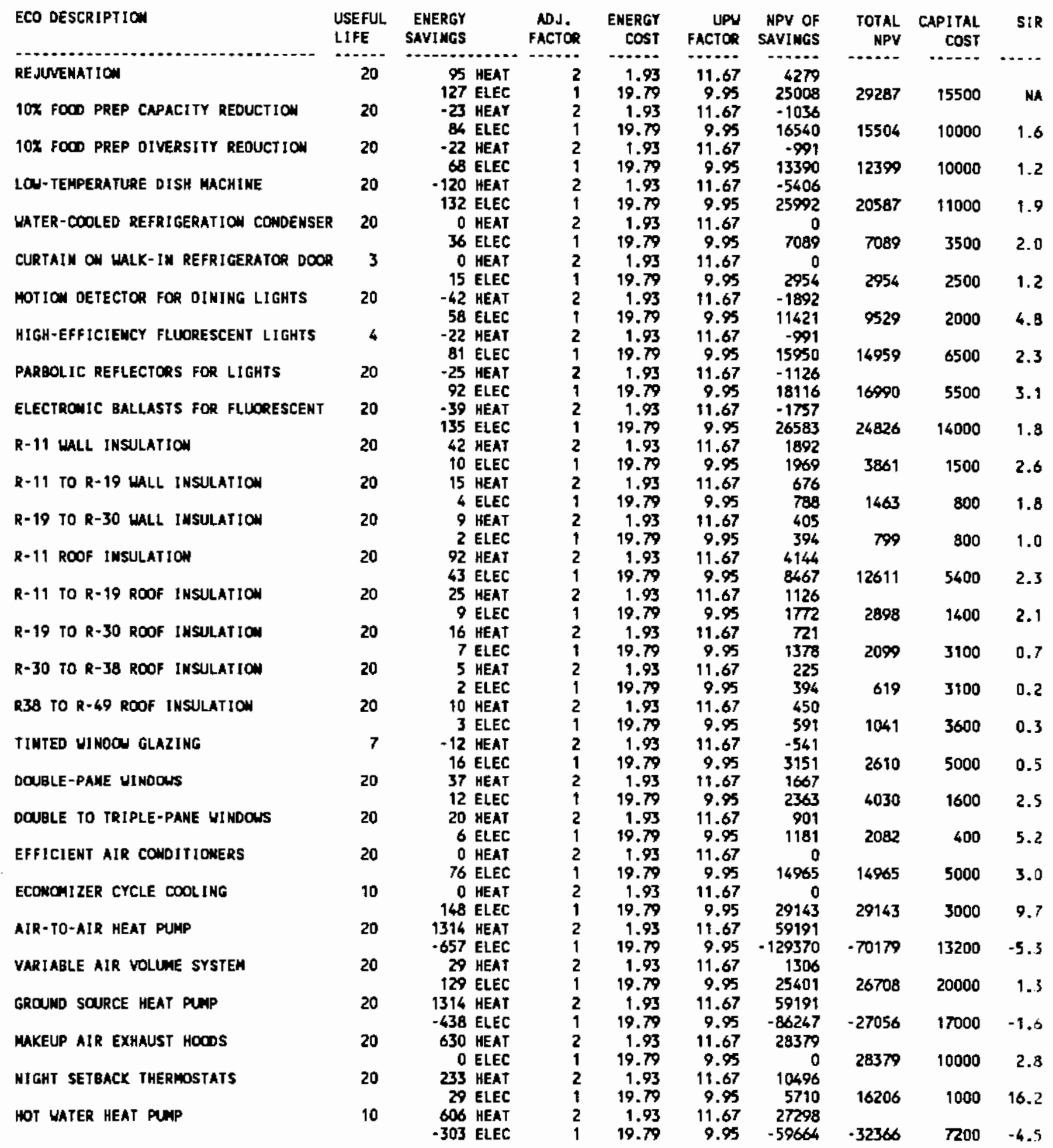


TABLE 6.10. Sample Analys is for Cool Climate, Region 3 Fuel Costs, Steam Heat, New Building

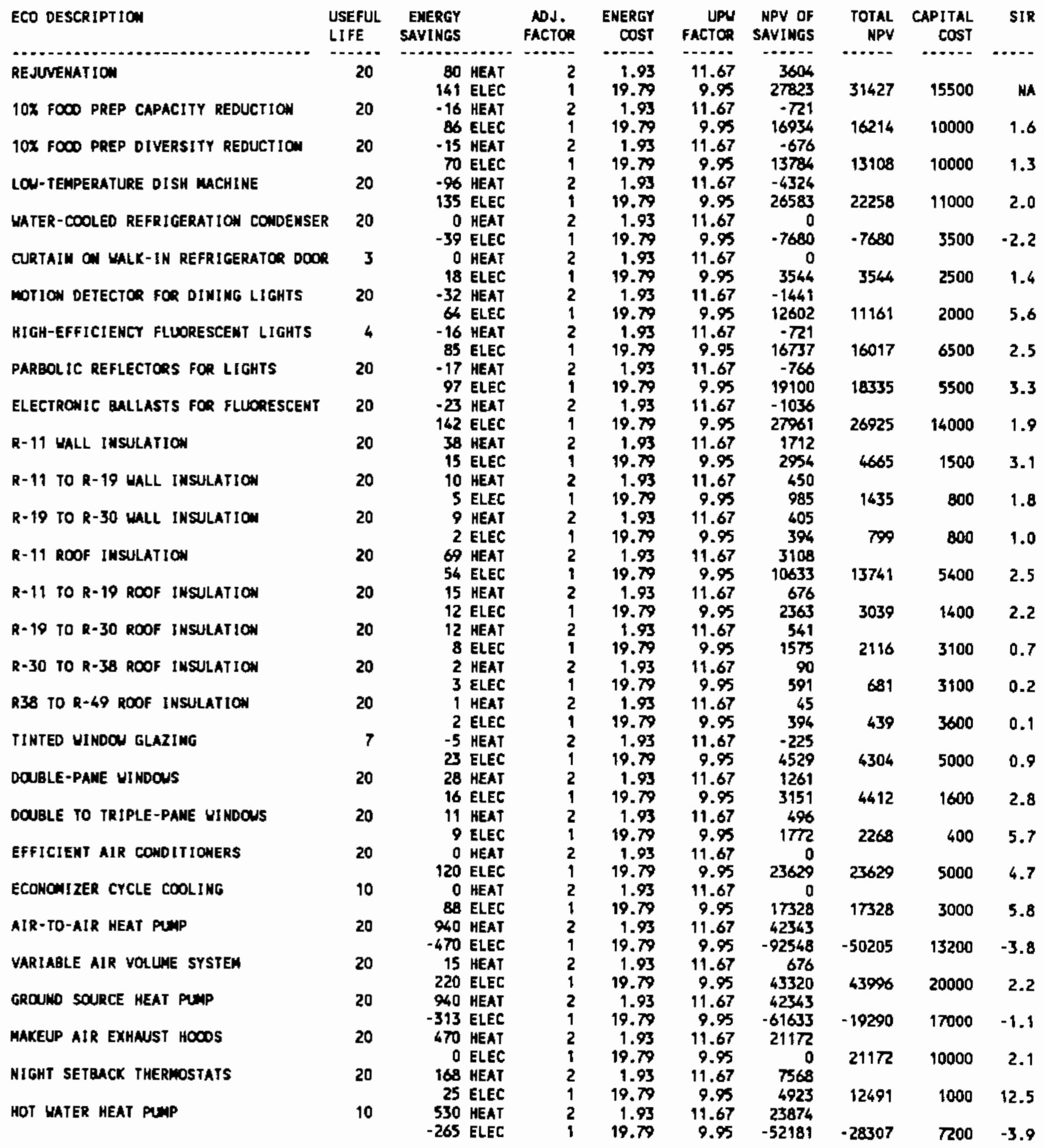


TABLE 6.11. Sample Analysis for Warm Climate, Region 3 Fuel Costs, Stealn Heat, New Building

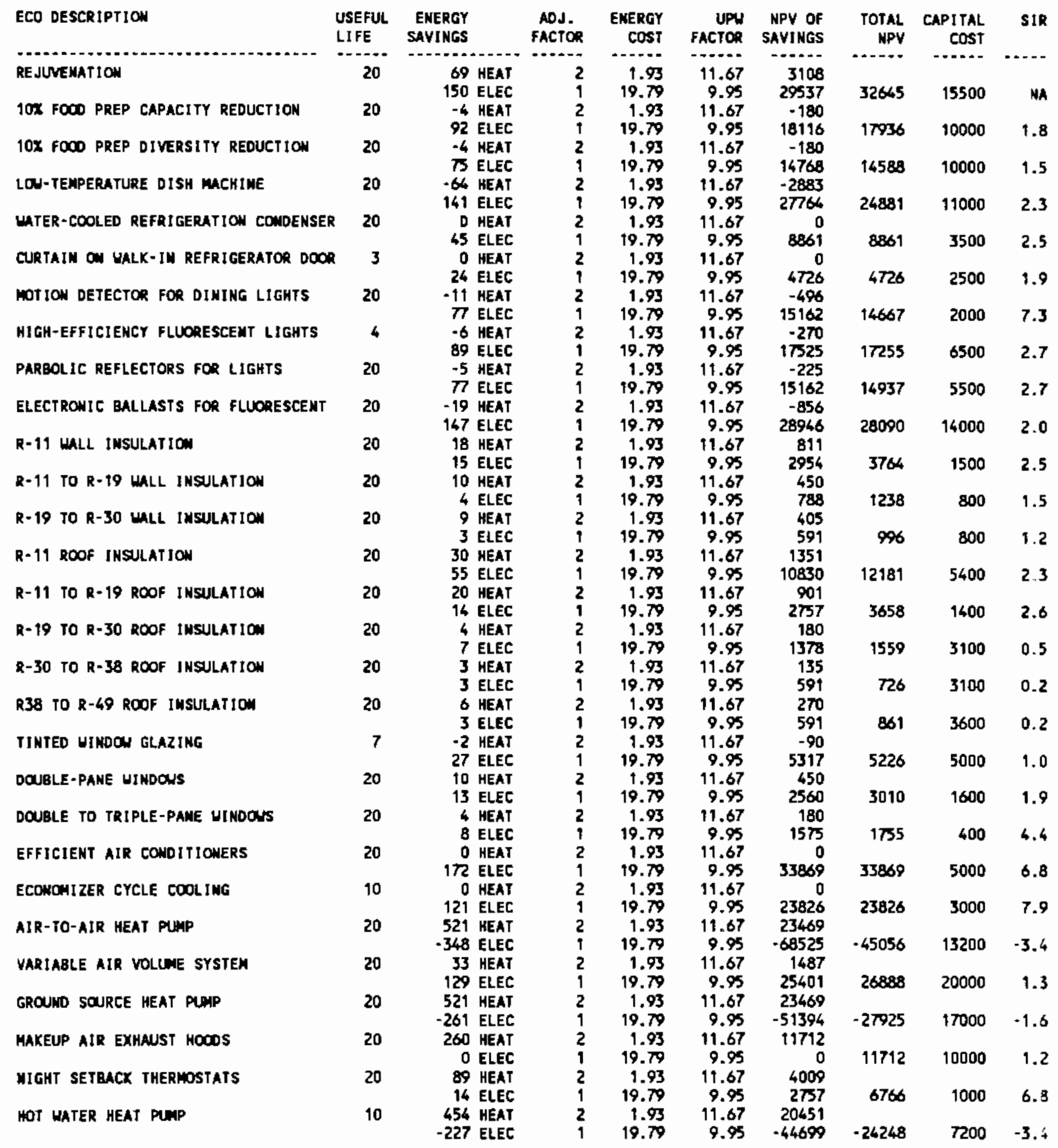


TABLE 6.12. Sample Analysis for Hot Climate, Region 3 Fuel Costs, Steam Heat, New Building

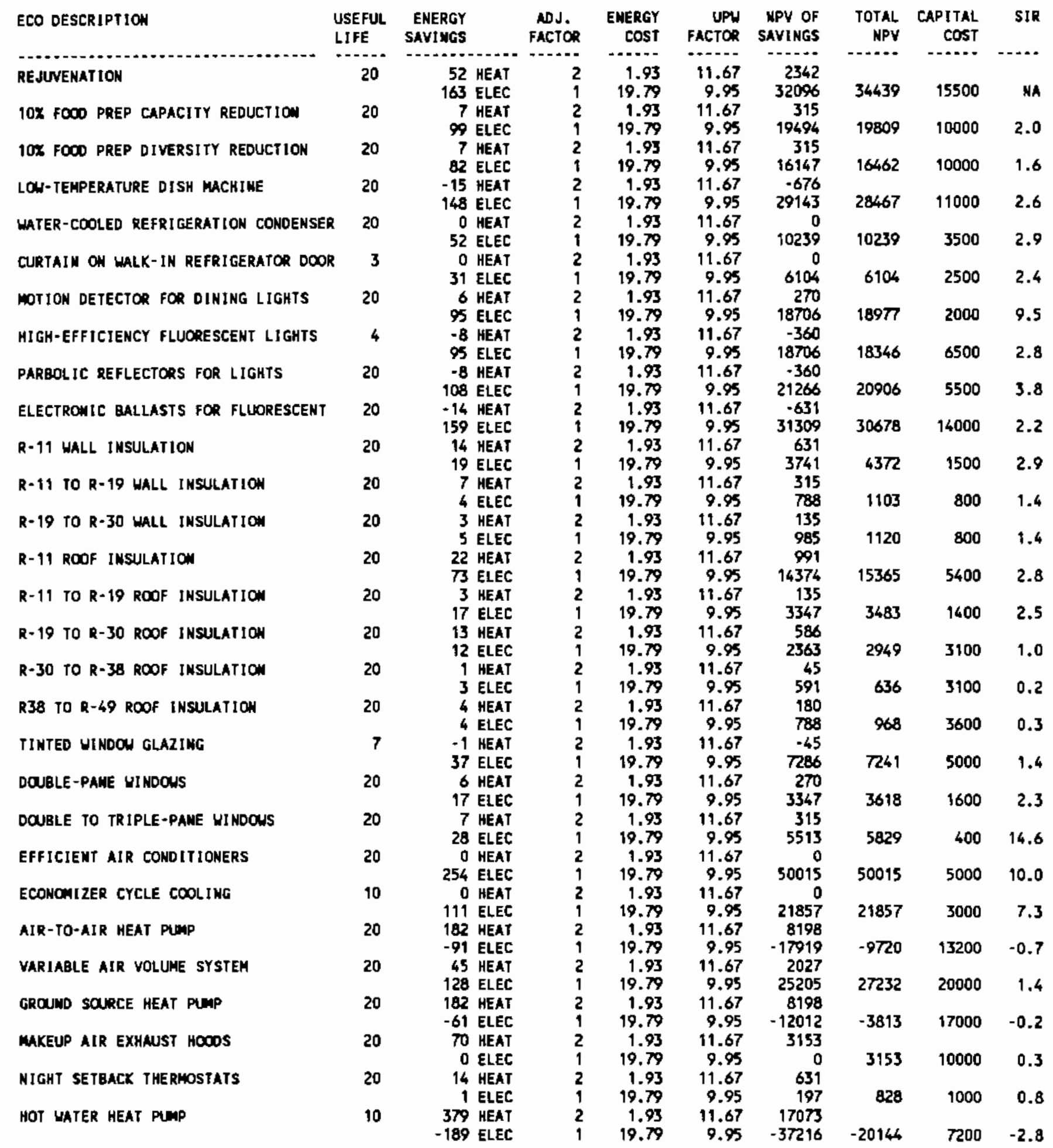


efficiency of the heating and cooling systems. As the system efficiencies are increased, the energy savings due to load reduction measures will diminish proportionately.

The energy costs are determined from the current issue of Energy Prices and Discount Factors for Life-Cycle Cost Analys is (Lippiatt 1987). The energy costs that apply for DOE Region 3 are listed on page 32. From this we find that commercial sector electricity is $\$ 19.79 / B t u \times 108$ and coaT-produced steam is valued at $\$ 1.93 /$ Btu $\times 108$.

Next, the uniform present worth factors for each measure are determined from the appropriate table from the same reference (Lippiatt 1987), p.7. To determine the appropriate factor, first find the column for the fuel used. Then select the row that corresponds to the useful life of the conservation measures. The lifetimes estimated for the prototype measures are listed on the forms. Remember, for comparative analyses, a 20-year life should be assumed, and the capital costs shoutd be adjusted accordingly.

To determine the net-present-value of the energy savings, multiply the energy savings by the adjustment factor by the energy cost by the uniform present worth factor for each fuel. Be careful to keep track of the sign, because the next step involves summing the NPV for each fuel to estimate the total NPV for each measure. For a measure to be cost-effective, it must cost less than the total NPV of energy savings. To determine the relative costeffectiveness of various measures, enter an estimate of the capital costs over a 20-year lifetime and divide this number into the total NPV. The result-the savings to investment ratios--should be entered in the last column.

The results of these sample analysis are summarized in Tables 6.13 and 6.14 by displaying the saving-to-investment ratios calculated for the all electric and district heated new dining halls is each climate type, respectively. The greater this ratio, the more cost-effective the conservation opportunity. If the saving to investment ratio is less than 1.0, the measure is not cost-effective. Where district heat is available some of the measures result in negative savings to investment ratios. This results from the fact that a more expensive fuel (electricity) is being substituted for cheaper 
TABLE 6.13. Summary of Savings to Investment Ratios, Region 3 Fuel Costs, Electric Heat, New Buidling

ECO DESCRIPTION

10\% FOOD PREP CAPACITY REDUCTION
$10 \%$ FOOD PREP DIVERSITY REDUCT
LOW-TEMPERATURE DISH MACHINE
WATER-COOLED REFRIGERATION CON
CURTAIN ON WALK-IN REFRIGERATO
MOTION DETECTOR FOR DINING LIG
HIGH-EFFICIENCY FLUORESCENT LI
PARBOLIC REFLECTORS FOR LIGHTS
ELECTRONIC BALLASTS FOR FLUORE
R-11 WALL INSULATION
R-11 TO R-19 WALL INSULATION
R-19 TO R-30 WALL INSULATION
R-11 ROOF INSULATION
R-11 TO R-19 ROOF INSULATION
R-19 TO R-30 ROOF INSULATION
R-30 TO R-38 ROOF INSULATION
R38 TO R-49 ROOF INSULATION
TINTED WINDOW GLAZING
DOUBLE-PANE WINDOWS
DOUBLE TO TRIPLE-PANE WINDOWS
EFFICIENT AIR CONDITIONERS
ECONOMIZER CYCLE COOLING
AIR-TO-AIR HEAT PUMP
VARIABLE AIR VOLUME SYSTEM
GROUND SOURCE HEAT PUMP
MAKEUP AIR EXHAUST HOODS
NIGHT SETBACK THERMOSTATS
HOT WATER HEAT PUMP

$\begin{array}{rrrr}\text { COLD } & \text { COOL } & \text { WARM } & \text { HOT } \\ \text { SIR } & \text { SIR } & \text { SIR } & \text { SIR } \\ --- & -r- & -r .- & --- \\ 1.4 & 1.6 & 2 & 2.4 \\ 1.1 & 1.3 & 1.6 & 2.1 \\ 0.3 & 0.8 & 1.6 & 2.8 \\ 2.4 & 2.6 & 3 & 3.4 \\ 1.4 & 1.7 & 2.2 & 2.9 \\ 1.8 & 3.7 & 7.6 & 11.7 \\ 2.1 & 2.5 & 2.9 & 3.1 \\ 2.8 & 3.4 & 3 & 4.2 \\ 1.6 & 2 & 2.1 & 2.4 \\ 8 & 8.2 & 5.1 & 5.1 \\ 5.5 & 4.3 & 4 & 3.2 \\ 1.7 & 3.2 & 3.5 & 2.3 \\ 5.8 & 5.3 & 3.6 & 4.1 \\ 5.6 & 4.5 & 5.6 & 3.3 \\ 1.7 & 1.5 & 0.8 & 1.9 \\ 0.5 & 0.4 & 0.4 & 0.3 \\ 0.8 & 0.2 & 0.6 & 0.5 \\ 0.2 & 0.8 & 1.2 & 1.7 \\ 7.1 & 6.4 & 3.3 & 3.3 \\ 15 & 11.5 & 6.9 & 20.2 \\ 3.5 & 5.5 & 7.9 & 11.7 \\ 11.4 & 6.8 & 9.3 & 8.5 \\ 11.5 & 8.2 & 3 & 1.6 \\ 1.8 & 2.7 & 1.9 & 2 \\ 11.9 & 8.5 & 3.5 & 1.6 \\ 14.5 & 10.9 & 6 & 1.6 \\ 60.5 & 44.6 & 23.8 & 3.5 \\ 9.7 & 8.5 & 7.3 & 6.1\end{array}$


TABLE 6.14. SUMMARY OF SAVINGS TO INVESTMENT RATIOS REGION 3 FUEL COSTS, DISTRICT HEAT, NEW BUILDING

\begin{tabular}{|c|c|c|c|c|}
\hline ECO DESCRIPTION & $\begin{array}{r}\text { COLD } \\
\text { SIR }\end{array}$ & $\begin{array}{c}\mathrm{COOL} \\
\text { SIR }\end{array}$ & $\begin{array}{l}\text { WARM } \\
\text { SIR }\end{array}$ & $\begin{array}{l}\text { HOT } \\
\text { SIR }\end{array}$ \\
\hline FOOD PREP CAPACITY REDUCT & 1.6 & 1.6 & 1.8 & \\
\hline FOOD PREP DIVERSITY $R$ & & 1.3 & & 1.6 \\
\hline $\begin{array}{l}\text { W-TEMPERATURE DISH MACHINE } \\
\text { TER COOLED REFRIGERATION CONDENSERS }\end{array}$ & 1.9 & & 2.3 & 2.6 \\
\hline $\begin{array}{l}\text { TER COOLED REFRIGERATION CONDENSERS } \\
\text { RTAIN ON WALK-IN REFRIGERATOR DOORS }\end{array}$ & & -2.2 & & 2.9 \\
\hline RTAIN ON WALK-IN REFRIGERATOR DOORS & 1.2 & 1.4 & 1.9 & 2.4 \\
\hline $\begin{array}{l}\text { TION DETECTOR FOR DINING LIGHTS } \\
\text { GH-EFFICIENCY FLUORESCENT LIGHTS }\end{array}$ & & $\begin{array}{l}5.6 \\
2.5\end{array}$ & 7.3 & $\begin{array}{l}9.5 \\
2.8\end{array}$ \\
\hline RBOLIC REFLECTORS FOR LIGHTS & & 3.3 & 2.7 & 3.8 \\
\hline $\begin{array}{l}\text { ECTRONIC BALLASTS FOR FLUORESCENT FIXTURES } \\
11 \text { WALL INSULATION }\end{array}$ & 1.8 & 1.9 & & 0 \\
\hline 11 TOR-19 WALL INSULATION & 1.8 & $\begin{array}{l}3.1 \\
1.8\end{array}$ & $\begin{array}{l}2.5 \\
1.5\end{array}$ & i. \\
\hline TO R-30 WALL INSULATION & & & 1.2 & 1. \\
\hline ROOF INSULATION & 2. & 2.5 & 2.3 & 2.8 \\
\hline $\begin{array}{l}\text { TO } \mathrm{R}-19 \text { ROOF INSULATI } \\
\text { TO R-30 ROOF INSULATI }\end{array}$ & & 2.2 & 2.6 & 2.5 \\
\hline 30 TO R-38 ROOF INSULA & 0.2 & $\begin{array}{l}0.7 \\
0.2\end{array}$ & $\begin{array}{l}0.5 \\
0.2\end{array}$ & 0.2 \\
\hline TO R-49 ROOF INSULATION & & 0.1 & 0.2 & \\
\hline WINDOW G & & 0.9 & & \\
\hline $\begin{array}{l}\text { BLE-PANE WINDOWS } \\
\text { BLE TO TRIPLE-PANE WI }\end{array}$ & 2 . & 2.8 & & 2.3 \\
\hline IENT AIR CONDITIONERS & & 4.7 & $\begin{array}{l}4.4 \\
6.8\end{array}$ & $\begin{array}{l}4.0 \\
10\end{array}$ \\
\hline ZER CYCLE COOLING & & 5 & 7 & 7 \\
\hline AIR HEAT PUMP & & -3 & -3.4 & -0 . \\
\hline E AIR VOLUME SYS & & 2. & 1.3 & 1 \\
\hline RCE HEAT PUMF & & -1 & -1 & -0 \\
\hline Yo & & 6 & 1 & \\
\hline & & 12.5 & 6.8 & U \\
\hline & & -3 & -3.4 & \\
\hline
\end{tabular}


fossil fuels. Although site energy consumption is reduced, the costs of this energy increase by the fuel-switching. 


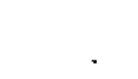




\subsection{CONCLUSIONS AND RECOMMENDATIONS}

This section provides general conclusions and recommendations for the analysis of energy conservation potential in USAF dining halls. The relative energy intensity of the prototype facility is indicated, and the analysis methods are reviewed. The results of the sample analysis presented in Section 6 are reviewed to make general statements regarding the cost-effectiveness of the energy conservation measures examined.

\subsection{GENERAL CONCLUSIONS}

Food service facilities are known to be among the most energy intensive commercial building types, owing to the substantial food preparation, sanitation, and ventilation energy demands. The prototype dining hall was found to consume an estimated $480,000 \mathrm{Btu} / \mathrm{ft} 2 / \mathrm{yr}$. Seven other restaurants metered for the NRA had energy use intensities ranging from 390,000 to 730,000 Btu ft2/yr, placing the dining hall in the lower quartile. This is partially due to the relatively large size of this facility. Private sector restaurants generally have smaller kitchens, office/storage areas, and dining rooms.

The end-use consumption levels on a use per square foot basis for the dining hall are generally comparable to the other facilities. The requirements for HVAC are on the high side, however, due to the low levels of insulation and the inefficient air conditioning and heating systems in the prototype.

The energy use measurements taken at the prototype facility provide valuable insights into the energy use shares and consumption profiles. In addition, these measurements were very useful for calibrating the simulation model used to estimate energy savings. Once initialized, the ASEAM 2.1 simulation model was quick and easy to use, and capable of simulating the performance of all but one of the conservation measures evaluated. Of particular value is the parametric processor, which permits a series of comparative analyses to be conducted automatically. This feature was used to conduct extensive sensitivity analyses to ensure the reasonableness of the energy savings estimates. 
Although the model has the capability to conduct detailed life-cycle-cost analyses, this feature was not used for this study. Instead, the tabular approach for the economic analysis was developed for use by those not familiar with computers and simulation modeling. Based upon four carefully selected climate types, this approach combines the results of ASEAM 2.1 simulations with the life-cycle costing methods mandated for federal building conservation asses sments.

Application of all the measures found to be cost-effective for the prototype facility would result in a reduction of energy use from 20 to $35 \%$, without adversely affecting comfort or quality of service. The total cost of these measures ranges from approximately $\$ 75,000$ to $\$ 125,000$ per facility. The cost-effective energy savings and justified conservation measure costs are greatest where fuel prices are high and climates are extreme.

\subsection{GENERAL RECOMMENDATIONS}

This section provides general conclusions and recommendations for improving the energy efficiency of USAF dining halls. To confirm the appropriateness of these general recommendations for a particular case study, it is necessary to carry out the simplified analysis procedure or run the ASEAM mode1. The conclusions presented here are based upon a sensitivity analys is using a single set of fuel costs, estimated costs for conservation measures applied to the prototype dining hall, and two fuel supply scenarios in each of the four climate types.

A1l of the load reduction measures listed in the tables are cost effective in all climate types with district heat. The same is true if the building is all electric, except for the low temperature dishmachines, where the waste heat would otherwise offset space heating requirements. The cost effective level of wall and roof insulation is very dependent upon climate type and the costs of heating fuel. However, R-19 wall and roof insulation is costeffective in all cases for new construction. Inexpensive triple pane windows are also cost effective in new construction, however, window tinting is only cost effective in the warm and hot climates. Since these are load reduction 
measures their cost effectiveness would be lower if substantial system efficiency improvements are made.

With respect to system efficiency improvenents, the use of night set-back thermostats is very cost effective, particularly in colder climates. This cost effectiveness will be somewhat lower where electricity is the heating fuel and peak demand charges are based upon early morning peaks. Use of more efficient air conditioning systems, variable air volume distribution systems, and economizer cycles are cost effective in all cases. Heat pumps for space heating and water heating are cost effective only if electricity is used for these functions.

\subsection{LIMITATIONS OF THE SIMPLIFIED METHOD}

As a simplified method, many assumptions are made. The greatest leap is the assumption that the characteristics of the building to be retrofitted are identical to those of the prototype. The next greatest leap is that the climate area properly reflects the conditions of the building's location. Finally, the simulations assume that buildings are properly maintained and operated. If this is not the case, savings may be considerably lower than estimated. For these reasons, the results of the simplified analysis should be used only as a guide for further analysis rather than as a rigorous estimate of actual savings.

The simplified method can reveal the sensitivity of climate effects by carrying out the analysis for several climate areas. This is particularly called for if the location of interest lies far from the selected climate location on Figure 3.6. Additional sensitivities can be analyzed by altering adjustment factors, fuel prices, uniform present worth factors, or capital costs. Such sensitivities are usually quite useful if the savings-toinvestment ratios are close to 1.0 , so as to better determine the likelihood that the measures will be cost-effective.

Because of these limitations of the simple method, and the requirement to examine a limited set of conservation options, Appendix B provides a description of the ASEAM2.1 input file for the prototype dining hal1. The FEMP periodically conducts workshops on the use of this model at no charge to 
federal users, and many users may be able to master the program by using a tutorial provided with the software. With the detailed inputs derived from Appendix $B$ to start with, modifications to examine the specific characteristics of the building in question will be simple in most cases. The model can then be run with local weather data (if available) to develop a more accurate estimate of energy savings, life-cycle costs, and savings-to-investment ratios for a wide variety of energy conservation opportunities. 


\subsection{REFERENCES}

ACEC Research \& Management Foundation. 1987. A Simplified Energy Analysis Method - ASEAM 2.1, Second Edition. Washington, D.C.

American Society of Heating, Refrigerating, and Air Conditioning Engineers, Inc. 1985. Fundamentals Volume. Atlanta, GA.

Claar, C. N., R. P. Mazzucchi, and J. Hejdell. 1985. The Project on Restaurant Energy Performance End-Use Monitoring and Analysis. PNL-5462. Pacific Northwest Laboratory, Richland, WA.

IES Lighting Handbook. 1981. Illuminating Engineering Society of North America, New York, New York.

Lippiatt, B. C. and R. T. Ruegg. 1987. Energy Prices and Discount Factors for Life-Cycle Cost Analysis. National Bureau of Standards Special Pubtication 709 (Rev. 6/87), U.S. Department of Commerce, Gaithersburg, MA.

Ruegg, R. T. 1987. Life Cycle Costing Manual for the Federal Energy Management Program. National Bureau of Standards Handbook 135 (Rev. 1987). U.S. Department of Commerce, Gaithersburg, MD. 

APPENDIX A

ASEAM 2.1 MODELING AND CALIBRATION PROCESS 
APPENDIX A

\section{ASEAM 2.1 MODELING AND CALIBRATION PROCESS}

\section{GENERAL BUILDING DESCRIPTION}

The building is an Air Force dining hall located in Dover, Delaware, and has over 12,000 ft2 of conditioned floor area. For the simulation model, this area was divided into 10 zones. The zoning is based on four major factors:

- internal walls

- use patterns

- exposure

- model limit of 10 zones maximum.

Internal walls separate most of the zones. The dining rooms are treated as separate zones because they have different use patterns and exposure. The storage area and small office are combined because the small office has little floor area.

The building is heated by hot water supplied to four fan coils and five convectors. Cooling is supplied by two vapor compression air conditioning units, one for the east side and one for the west side of the building. The kitchen, however, is not cooled. Sixteen exhaust fans remove heat and odors while a heating and ventilating unit, along with the fans of the packaged air conditioning units, supply fresh makeup air.

\section{CALIBRATION AND BASE CASE DEVELOPMENT}

Before the impact of energy conservation measures can be evaluated, the base case must be defined. Definition consists of specifying building envelope parameters, lighting, equipment, occupancy levels and schedules, heating, ventilation, and air conditioning (HVAC) systems and plant. 
Building Envelope Parameters

A detailed breakdown of envelope parameters is given in Appendix B. Items specified for each zone are external wall areas and orientations, roof areas, window and door areas. Heat conductances (U-values) are entered for each. Shading coefficients for windows and space mass parameters are also specified along with infiltration.

In addition to external envelope characterization, internal zone parameters are specified. The temperatures of each zone were obtained from the metered data which, along with internal wall areas and conductances, allow ASEAM to account for interzonal conduction.

In ASEAM, infiltration by crack length and number of air changes can both be specified and are additive. Since the dining hall is designed to be slightly pressurized, infiltration can be ignored, except for three situations. In the cashier's office, the $A C-1$ return draws more than the supply. Thus, 6 air changes per hour (ACH) infiltration was estimated. Similarly, in the locker room, imbalance of exhaust and supply is about $0.5 \mathrm{ACH}$. The fact that the dishwashing area exhaust fans do not work means that hot air from the heating and ventilating unit (H\&V) and the dishwasher is introduced into the dining areas. In the summertime, this puts additional load on the air conditioners. This is modeled in ASEAM by adding infiltration to the dining areas and by adding $25 \%$ of the dishwasher capacity to dining room unhooded equipment.

\section{Lighting}

The lighting throughout the building is fluorescent except in the snack line (Zone 1) where fluorescent lighting was replaced with decorative incandescent fixtures.

Table A.1 shows lighting by zone (summarized from Appendix B) and compares the nameplate capacity (light bulb count) to measured peaks. In some cases, the measured channels are "polluted" with minor equipment and outlets. Thus, the sum of lighting and equipment consumption is used to calibrate the model. 
TABLE A.1. LIGHTING CAPACITIES

Zone $\begin{gathered}\text { Nameplate } \\ \text { Capacity, kW }\end{gathered} \begin{gathered}\text { Nameplate } \\ \text { Capacity, } W / \mathrm{ft} 2\end{gathered} \quad \begin{gathered}\text { Annual } \\ \text { Peak Hour, kW }\end{gathered}$

$\begin{array}{llll}1 & 6.14 & 1.57 & 14.8 \\ 2 & 8.68 & 2.23 & 8.62 \\ 3 & 1.15 & 1.38 & 1.89 \\ 4 & 6.07 & 2.29 & 8.57 \\ 5 & 0.97 & 1.00 & 1.44 \\ 6 & 2.14 \mathrm{M} & 5.81 \mathrm{M} & 0.42 \\ 7 & 1.12 \mathrm{M} & 1.37 \mathrm{M} & 1.46\end{array}$

$M=$ Mixed with Equipment

Lighting schedules from each zone were found from analyzing the metered hourly data and entered into the model as occupied, unoccupied and monthly diversity factors. It was found that the monthly diversity factors can vary substantially from zone to zone, but there are not enough schedule input columns in ASEAM to accommodate a set of monthly diversity factors for each zone. Thus, a single set of monthly diversity factors for all zones is used.

\section{Equipment}

The dining hall equipment is all electric (ASEAM cannot model nonelectric equipment) and is hooded or unhooded.

Table A.2 summarizes total equipment capacity by zone along with the measured peak hour. The breakdown by hooded and unhooded equipment is detailed in Appendix B. Table A.3 shows the information taken from drawirgs and site visits that was used to produce Table A.2 and ASEAM inputs.

Equipment schedules were obtained for hooded and unhooded equipment by zone from the metered data. Monthly diversity factors varied dramatically from zone to zone and between hooded and unhooded equipment.

However, because of ASEAM's limited schedule input, only one set of monthly diversity factors was entered to represent both types of equipment in 


\section{TABLE A.2. TOTAL EQUIPMENT CAPACITIES}

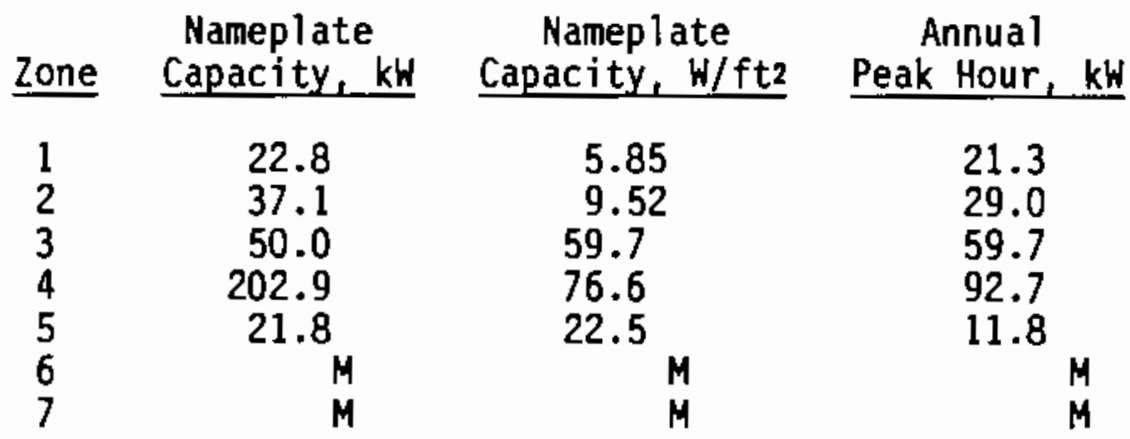

$M=$ Mixed with Lights

all zones. Because of this limitation, it would be very difficult to evaluate specific equipment modifications.

Internal gains from hooded equipment are treated by ASEAM as recommended in the American Society of Heating, Refrigerating, and Air-Conditioning Engineers, Inc. (ASHRAE 1985) fundamentals. However, ASEAM does not adjust the internal gain fraction.

OCCUPANCY

Occupancy capacity by zone is summarized from Appendix B in Table A.4.

Occupancy schedules for the Air Force Dining Hall vary slightly from day to day, but generally do not have a weekday/weekend pattern. This is fortunate, because ASEAM does not distinguish weekdays and weekends.

The day is divided into occupied and unoccupied periods based on an overall activity level. The monthly diversity factors for the two dining rooms are obtained from meal count data collected by the Air Force. Monthly diversity factors for the kitchen, dishwashing room, office, storage, and locker areas were assumed.

The sensible and latent loads per person shown in Appendix $B$ are based on assumed activity level and ASHRAE Fundamentals. 
TABLE A.3. INDIVIDUAL EQUIPMENT CAPACITIES

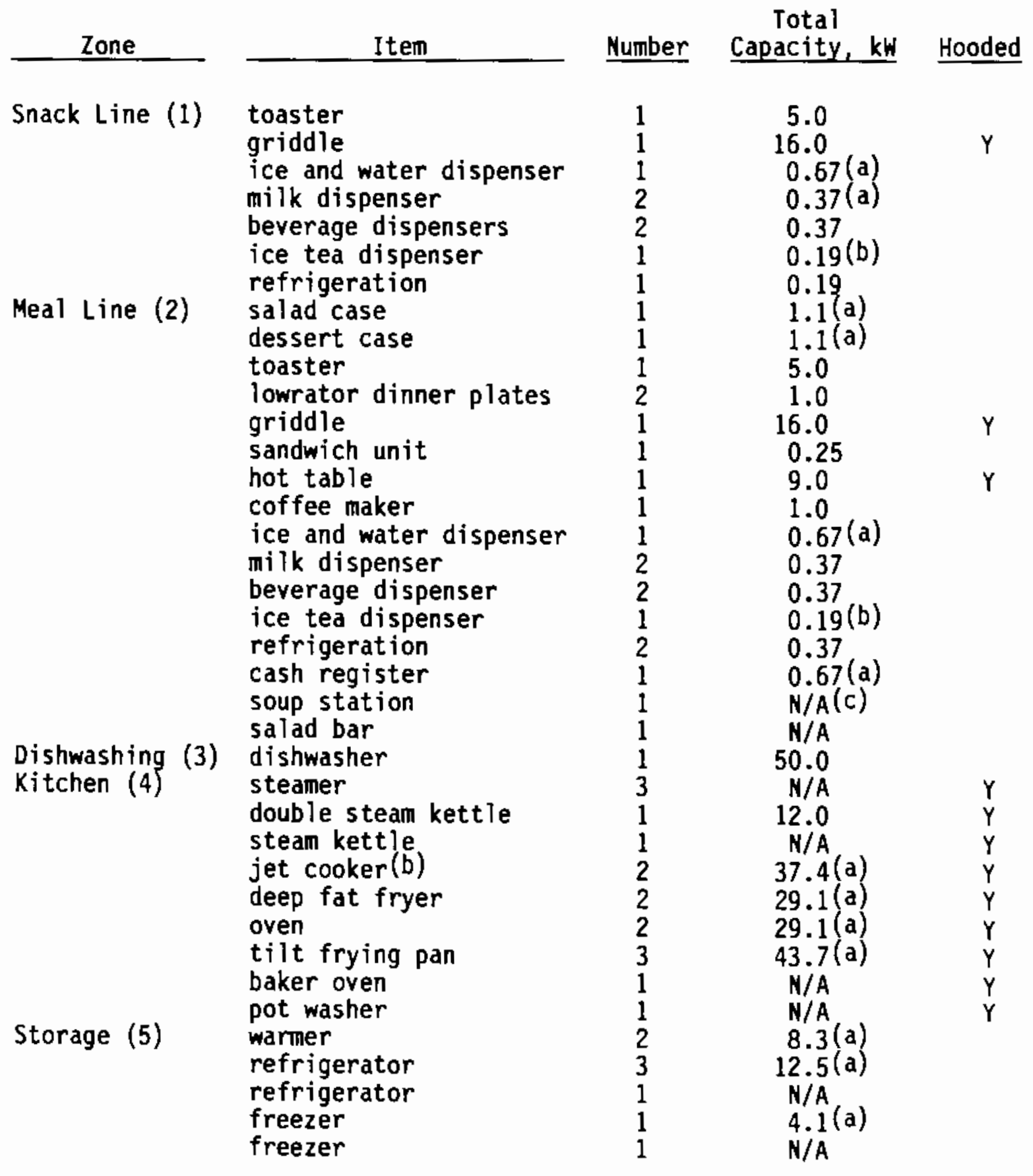
(a) Computed from current and voltage
(b) Not used
(c) $N / A=$ not applicable 
TABLE A.4. OCCUPANCY

$\begin{array}{rrr}\text { Zone } & & \text { Capacity } \\ 1 & & 150 \\ 2 & & 150 \\ 3 & 3 \\ 4 & 10 \\ 5 & 2 \\ 6 & 3 \\ 10 & 10\end{array}$

\section{HVAC Systems}

The dining hall is served by four HVAC systems, two vapor compression air conditioners, one heating and ventilating unit, and multiple hot water heating coils and convectors. In addition, there are sixteen exhaust fans. Table A.5 shows the HVAC system equipment.

This system configuration must be restructured to fit ASEAM modeling. System component capacities were broken out by zone based on measured air flow rate to the zone. For each zone, the heating components, cooling components and fan components were added to obtain heating (BUTH), cooling (tons), and fan capacity ( $\mathrm{kW}$ and CFM) for each zone. Then, Zones 1 and 2 were modeled as having their own single re-heat with direct expansion cooling systems, and Zones 3 and 7 were modeled with H\&V unit heating and Zones 4, 5, and 6 were modeled by multi-zone reheat with direct expansion cooling. This model underestimates heating demand because the air supplied from the H\&V unit to the kitchen hoods is not included. Thus, infiltration is added to Zone 3 to make up the difference. The detailed breakdown by zone is in Appendix B.

Plant

The plant consists of an electricity source and a district heating source. In ASEAM, this is also where hot water is specified. Specifying hot water consists of water heater capacity, annual average water demand, temperatures and losses. There is no provision for occupied, unoccupied or monthly diversity factors. 
TABLE A.5. SYSTEM

\begin{tabular}{|c|c|c|c|c|c|c|}
\hline Unit & $\begin{array}{c}\text { Heating } \\
\text { Capacity, KBH }\end{array}$ & $\begin{array}{c}\text { Cooling } \\
\text { Capacity, ton }\end{array}$ & $\begin{array}{c}\text { Fan } \\
\text { Capacity, kW }\end{array}$ & $\begin{array}{l}\text { Compressor } \\
\text { Capacity, kW }\end{array}$ & $\begin{array}{c}\text { Pump } \\
\text { Capacity, kW }\end{array}$ & Comments \\
\hline $\begin{array}{l}A C-1 \\
A C-2\end{array}$ & $\begin{array}{l}156 \\
156\end{array}$ & $\begin{array}{l}27.8 \\
28.1\end{array}$ & $\begin{array}{l}12 \\
12\end{array}$ & $\begin{array}{l}19.5 \\
19.7\end{array}$ & - & \\
\hline H\&V & 956 & $\begin{array}{ll}20.1 \\
-\end{array}$ & 10 & $\begin{array}{l}19.7 \\
-\end{array}$ & - & \\
\hline Air curtains (2) & - & - & .25 & - & & \\
\hline $\begin{array}{l}\text { Hot water } \\
\text { circulating pumps }\end{array}$ & - & - & - & - & 1.49 & \\
\hline $\begin{array}{l}\text { Domestic hot } \\
\text { water generator }\end{array}$ & 1200 & - & - & - & - & \\
\hline $\begin{array}{l}\text { Domestic hot } \\
\text { water pump }\end{array}$ & - & - & - & - & 0.19 & \\
\hline$U H-1$ & 6.7 & - & 0.02 & - & - & \\
\hline $\mathrm{UH}-2$ & 33.5 & - & 0.2 & - & - & \\
\hline$C-1$ & 1.5 & - & - & - & - & \\
\hline $\begin{array}{l}c-2 \\
c-3\end{array}$ & 3.8 & - & - & - & - & \\
\hline $\begin{array}{l}c-3 \\
\text { Exhaust Fans (a) }\end{array}$ & 6.6 & - & - & - & - & \\
\hline $\begin{array}{l}\text { Zone } 1 \\
\text { EF-11,15 } \\
\text { and } 2\end{array}$ & - & - & 0.50 & - & - & $\begin{array}{l}\text { EF }-15 \text { serves } \\
\text { Zones } 1\end{array}$ \\
\hline $\begin{array}{l}\text { Zone } 2 \\
\mathrm{EF}-12,15\end{array}$ & - & - & 0.27 & - & - & \\
\hline $\begin{array}{l}\text { Zone } 3 \\
\text { EF-13,14 }\end{array}$ & - & - & 0.56 & - & - & Not operating \\
\hline $\begin{array}{l}\text { Zone } 4 \\
E F-1,2,3,4,5,9,10\end{array}$ & - & - & 2.05 & - & - & \\
\hline $\begin{array}{l}\text { Zone } 5 \\
\mathrm{EF}-7,8\end{array}$ & - & - & 0.37 & - & - & Not used \\
\hline $\begin{array}{l}\text { Zone } 6 \\
\text { None }\end{array}$ & - & - & 0 & - & - & \\
\hline $\begin{array}{l}\text { Zone } 7 \\
\mathrm{EF}-6\end{array}$ & - & - & 0.19 & - & - & \\
\hline
\end{tabular}

(a) EF-16 serves the mechanical room, which is not included in the building model. 
Because both the hot water for consumption and heating are served by district heat, ASEAM adds them together without reporting them individually. ANNUAL CONSUMPTION CALIBRATION

Calibration consisted of matching both annual and monthly consumptions. The results of the annual consumption calibration are shown in Table A.6. The confidence in heating calibration is low because we lacked sufficient metered data. The confidence in air conditioning is better than for heating because we had more data. Light, equipment and fan confidences are high because we had the best data for these. The reason that lights and equipment are not shown separately is that some of the metered data channels are mixed with lights and equipment.

\section{Calibrated and Base Case Models}

A calibrated model is produced to develop confidence in the modeling assumptions by matching metered evidence. A Base Case is then produced from the calibrated model to be more representative of all Air Force Dining Halls. Lights and Equipment Monthly Calibration

The results of the light and equipment calibration are shown in Figure A.1. The model and metered data match very well. This match is for the whole building and cannot be demonstrated for each zone by end-use because ASEAM has an insufficient number of schedule inputs.

Heating Monthly Calibration

The heating could not be calibrated on a monthly basis because the hot water heating system was not fully instrumented. However, an estimate of annual heating was obtained from one-time flow measurements and one week of measured temperature differences across heating coils in January, 1987. Infiltration in Zone 3 was added so that the model prediction was close to the estimated annual heating consumption. 


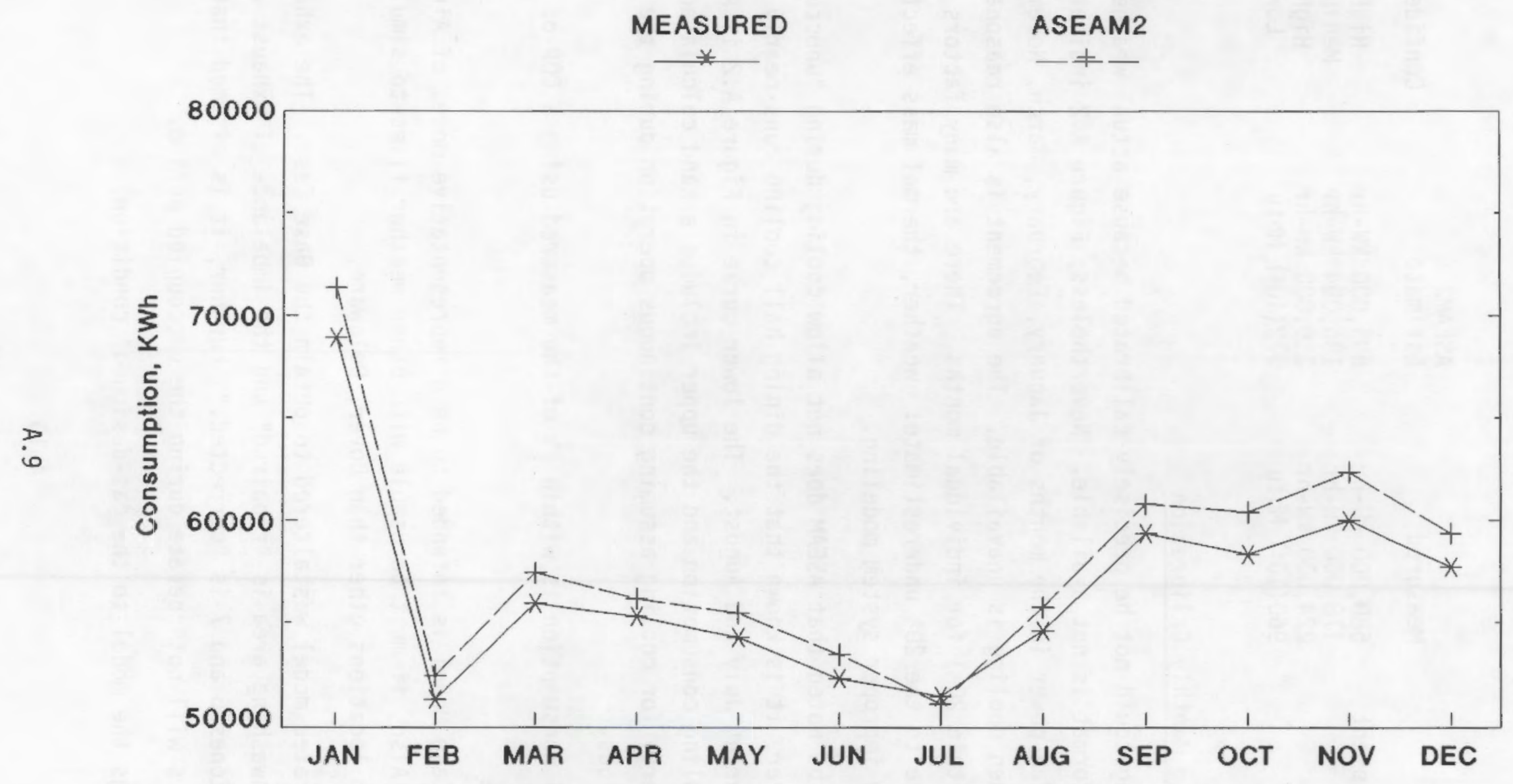

FIGURE A.1. Comparison of Measured and ASEAM 2.1 Estimated Lighting and Equipment Energy Consumption 
TABLE A.6. ANNUAL CONSUMPTION COMPARISON

$\begin{array}{lllc}\text { End-Use } & \text { Measured } & \text { ASEAM2 } & \text { Confidence } \\ & & \text { Estimate } & \\ \text { Lights and Equipment } & 680,000 \mathrm{~kW}-\mathrm{hr} & 693,000 \mathrm{~kW}-\mathrm{hr} & \text { High } \\ \text { Cooling } & 178,000 \mathrm{~kW}-\mathrm{hr} & 186,094 \mathrm{~kW}-\mathrm{hr} & \text { Medium } \\ \text { Fans } & 224,000 \mathrm{~kW}-\mathrm{hr} & 219,000 \mathrm{~kW}-\mathrm{hr} & \text { High } \\ \text { Heating } & 960(106) \mathrm{Mbtu} & 972(106) \mathrm{Mbtu} & \text { Low }\end{array}$

Fans and Cooling Monthly Calibration

The cooling could not be precisely calibrated because actual weather data in ASEAM format is not available. Nevertheless, Figure A.2 indicates good agreement for fan power in the months of January, February, March, November, and December when cooling is unavailable. The agreement is also reasonable for cooling (within 20\%) for individual months. There are many factors that could contribute to the $20 \%$ underestimate: weather, thermal mass effects, and potentially improper system modeling.

It should be noted that ASEAM does not allow cooling during "unoccupied" periods. However, it is known that the dining hall cooling runs nearly continuously during July and August. The lower curve in Figure A.2 is ASEAM's estimate of cooling consumption and the upper includes a hand calculated estimate of energy for cooling assuming continuous operation during the unoccupied periods.

The annual consumption is within $2 \%$ of the measured using a COP of 1.9 .

\section{BASE CASE MODEL}

The Base Case Model is intended to be a representative model of Air Force Dining Halls. Also, it must be usable with other weather files to simulate dining halls in locations other than Dover, Delaware.

The calibrated model was altered to obtain the Base Case. The exhaust fan in the dishwashing area is "repaired" and the imbalance of exhaust and supply air in Zones 6 and 7 is "corrected." Further, it is assumed that the air conditioners will not operate during the unoccupied period.

This brings the model to the "as-designed" condition. 


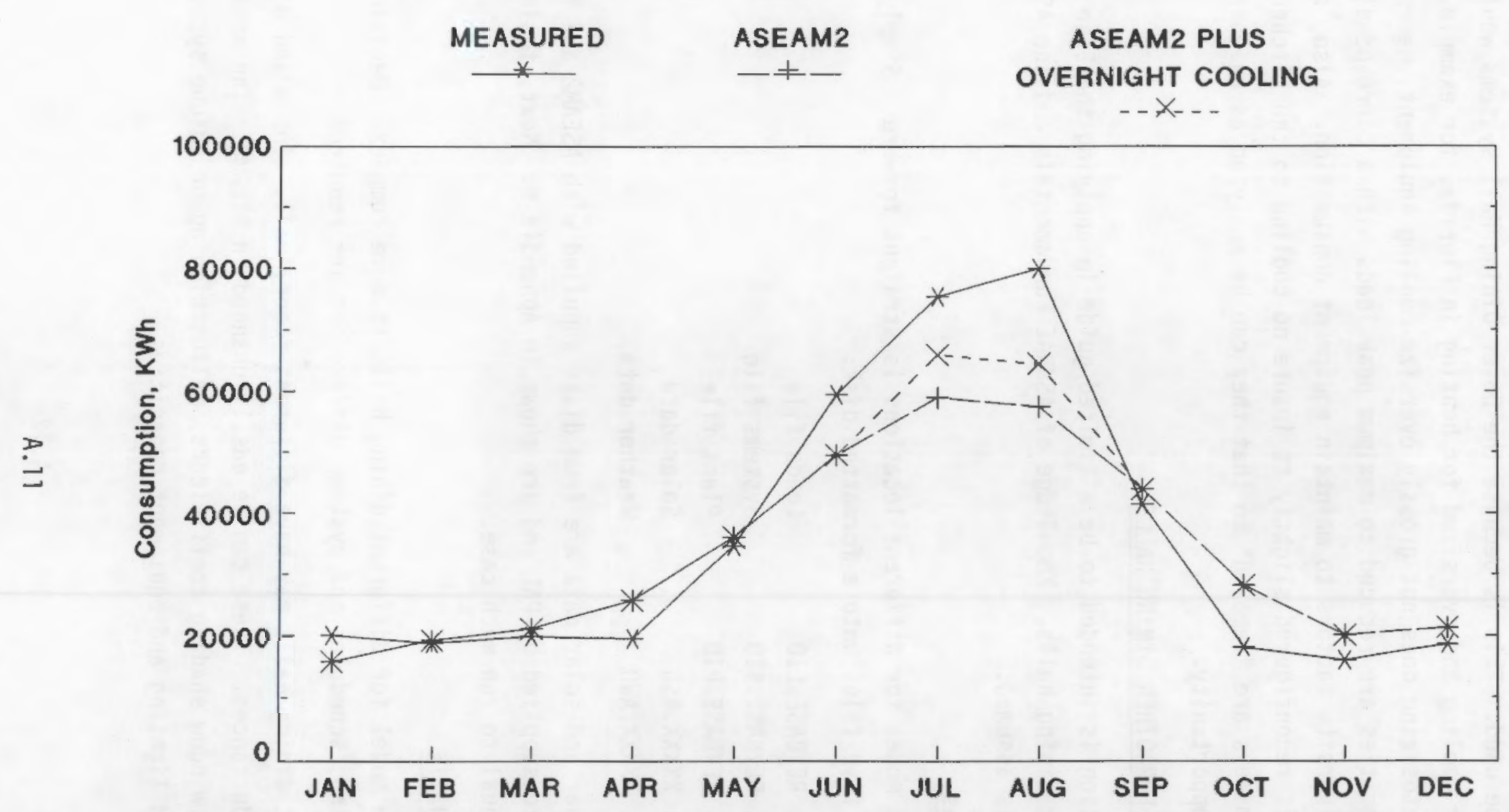

FIGURE A.2. Comparison of Measured and ASEAM 2.1 Estimated Fans and Cooling Energy 
In order to perform analyses for other locations, ASEAM's autosizing feature must be used. This is because the Dover Dining Hall systems would be undersized for cooling and oversized for heating in Florida, for example. To insure that autosizing does not grossly oversize cooling equipment, nameplate equipment capacities are reduced to maximum peak loads with a corresponding increase in diversity factors to maintain equipment consumption. Also, the system model is reconfigured slightly to insure no cooling to the kitchen. Lastly, economizers are "removed" so that they can be analyzed as an energy conservation opportunity.

USE OF ASEAM2 FOR OTHER DINING HALLS

This section is intended to be a limited guide in applying the Base Case model to other dining halls. Knowledge of ASHRAE Fundamentals and the ASEAM2 User's Guide is assumed.

\section{Other Locations}

Using the model for different locations is straight forward. Simply copy the following five files onto a formatted disk:
1. REVBASE.LID
Loads file
2. REVBASE.SID
Systems file
3. REVBASE.PID
Plant file
4. $X X X X X . N S D$
Solar data
5. $X X X X X$.AWD
Weather data.

The weather and solar data are from disks supplied with ASEAM2 and the other files are supplied by PNL and are shown in Appendix B. Next, follow the ASEAM2 manual to run each case.

\section{Other Dining Halls}

Using the model for different dining halls is more complex. Decisions regarding zoning, schedules and systems differences are required.

Different dining halls may have different floor, wall, window and door areas and conductances. These can be easily changed in ASEAM2. The areas to watch for are window shading coefficients, malfunctioning or unique system equipment, and lighting and equipment capacities. 
In the Base Case model, Zone 3 has $6 \mathrm{ACH}$ infiltration to account for $\mathrm{H} \& \mathrm{~V}$ unit air tempering of exhaust hood air. This may not be necessary or correct for other dining halls. Lighting and equipment capacities can be adjusted by the ratio of nameplate ratings. In the Base Case model, the capacities are annual peaks, not nameplate ratings.

Schedules or diversity factors can easily be changed, however, determination of the desired values is difficult. For dining hall occupancy schedules, meal count data can be used to obtain diversity factors. To obtain diversity factors for 1 ights and equipment requires metered data.

System modeling is not confined to four systems as in the Base case. The user may select and arrange ASEAM2 systems to fit the dining hall of interest. It is desirable to keep the number of systems in ASEAM small to facilitate updates and to minimize run-time. 
. 
APPENDIX B

ASEAM INPUT SCREENS FOR BASE CASE 
APPENDIX B

\section{ASEAM INPUT SCREENS FOR BASE CASE}

The input screens for the Base Case Air Force Dining Hall are presented by loads, systems, and plant input screens.

B. 1 
LOADS INPUT TO ASEAM2

B.2 
DATA ECHO FOR LOADS INPUT FILE: REVBASE.LID

\section{BUILDING/PROJECT DATA}

\begin{tabular}{|c|c|}
\hline $\begin{array}{l}\text { Building File Name } \\
\text { Building Name } \\
\text { Project Number }\end{array}$ & $\begin{array}{l}\text { : AF_DOVER } \\
: \text { Revised Base Case } \\
\text { : Correct Original }\end{array}$ \\
\hline Building Address & : DOVER DELAWARE \\
\hline Building Type & : RESTAURANT \\
\hline $\begin{array}{l}\text { Building gross floor area } \\
\text { Building net conditioned area } \\
\text { Number of zones }\end{array}$ & $\begin{array}{l}: 12928 \mathrm{ft} 2 \\
: 12584 \mathrm{ft} 2 \\
: 7\end{array}$ \\
\hline $\begin{array}{l}\text { Building Location } \\
\text { North latitude } \\
\text { West longitude } \\
\text { Time Zone Number } \\
\text { Daylight Savings Time }\end{array}$ & $\begin{array}{l}: 39.08 \mathrm{deg} \\
:=75.28 \mathrm{deg} \\
: 5\end{array}$ \\
\hline $\begin{array}{l}\text { Typical Weekday Operating Schedu } \\
\text { Occupancy start hour } \\
\text { Operating hours/day }\end{array}$ & $\begin{array}{l}1 \mathrm{e} \\
: 6 \\
: 16\end{array}$ \\
\hline $\begin{array}{l}\text { Summer Thermostat Schedule } \\
\text { Beginning month } \\
\text { Ending month }\end{array}$ & $\begin{array}{l}\text { : April } \\
: \text { October }\end{array}$ \\
\hline $\begin{array}{l}\text { Typical 0ccupied Schedule } \\
\text { Weekdays } \ldots \ldots \ldots \ldots \ldots \ldots \ldots \text { from } \\
\text { Saturdays } \ldots \ldots \ldots \ldots \ldots \ldots \text { from } \\
\text { Sundays } \ldots \ldots \ldots \ldots \ldots \ldots \text { from }\end{array}$ & $\begin{array}{l}600 \text { to } 2400 \\
: 600 \text { to } 2400 \\
600 \text { to } 2400\end{array}$ \\
\hline
\end{tabular}




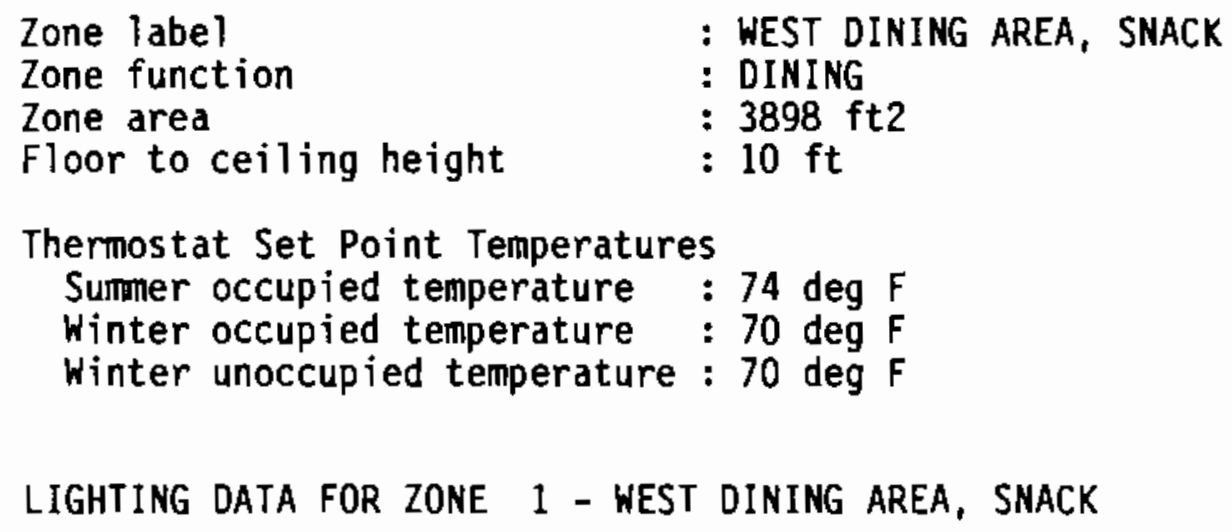

Thermostat Set Point Temperatures

Summer occupied temperature : $74 \mathrm{deg} F$

Winter occupied temperature : $70 \mathrm{deg} F$

Winter unoccupied temperature : $70 \mathrm{deg} F$

LIGHTING DATA FOR ZONE 1 - WEST DINING AREA, SNACK

Ltg Func 1 Ltg Func 2 Ltg Func 3 Ltg Func 4

\begin{tabular}{|c|c|c|}
\hline $\begin{array}{l}\text { Function name } \\
\text { Function area }(\mathrm{ft} 2)\end{array}$ & $\begin{array}{l}: \text { DINING } \\
: 3748\end{array}$ & $\begin{array}{l}\text { BATHROOM } \\
100\end{array}$ \\
\hline $\begin{array}{l}\text { Installed watts/ft2 } \\
\text { (times) Percent function area } \\
\text { Total installed watts }\end{array}$ & $\begin{array}{l}: \\
\vdots \\
:\end{array} 5636$ & 204 \\
\hline Daylighting analys is & : No & No \\
\hline $\begin{array}{l}\text { Lighting system type } \\
\text { Percent light heat to space } \\
A^{\prime} \text { Classification } \\
\text { 'B' Classification }\end{array}$ & $\begin{array}{l}: \\
: 80 \\
: i^{55}\end{array}$ & $\begin{array}{l}80 \\
.55\end{array}$ \\
\hline $\begin{array}{l}\text { Diversity factors - occupied } \\
\text { Diversity factors - unoccupied } \\
\text { Monthly diversity table number }\end{array}$ & $\begin{array}{l}: 50.4 \\
: 47.9 \\
: 4\end{array}$ & $\begin{array}{l}50.4 \\
47.9 \\
4\end{array}$ \\
\hline
\end{tabular}

PEOPLE DATA FOR ZONE 1 - WEST DINING AREA, SNACK

$\begin{array}{ll}\text { Number of people in zone } & : 150 \\ \text { Sensible load per person } & : 255 \text { BTUH per person } \\ \text { Latent load per person } & : 325 \text { BTUH per person } \\ & \\ \text { Diversity factor - occupied } & : 34 \\ \text { Diversity factor - unoccupied } & : 0 \\ \text { Monthly diversity table number } & : 1\end{array}$


ELECTRIC EQUIPMENT DATA FOR ZONE 1 - WEST DINING AREA, SNACK

\begin{tabular}{|c|c|c|c|c|}
\hline & Type 1 & & Type 2 & \\
\hline $\begin{array}{l}\text { Electric equipment name } \\
\text { Total installed watts } \\
\text { Hooded }\end{array}$ & $\begin{array}{l}: \text { SER-UNHOOD } \\
: 11000 \\
: \text { No }\end{array}$ & & $\begin{array}{l}\text { SER-HOODED } \\
7400 \\
\text { Yes }\end{array}$ & \\
\hline $\begin{array}{l}\text { Diversity factors - occupied } \\
\text { Diversity factors - unoccupied } \\
\text { Monthly diversity table number }\end{array}$ & $\begin{array}{l}: 36.3 \\
: 22.0 \\
: 3\end{array}$ & & $\begin{array}{l}36.3 \\
22.0 \\
3\end{array}$ & \\
\hline \multicolumn{5}{|c|}{ WALL DATA FOR ZONE 1 - WEST DINING AREA, SNACK } \\
\hline 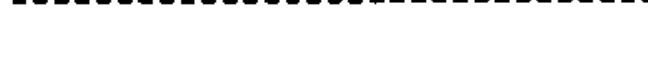 & Wall 1 & Wall 2 & Wall 3 & Wall 4 \\
\hline Name & $: N$ & $S$ & $W$ & NA \\
\hline $\begin{array}{l}\text { Wall orientation } \\
\text { Area (ft2) } \\
\text { U-Factor (BTUH/ft2-deg F) }\end{array}$ & $\begin{array}{l}: \text { North } \\
: 202 \\
: 0.111\end{array}$ & $\begin{array}{l}\text { South } \\
635 \\
.111\end{array}$ & $\begin{array}{l}\text { West } \\
727 \\
.111\end{array}$ & \\
\hline $\begin{array}{l}\text { Wall construction group } \\
\text { Color correction }\end{array}$ & $\begin{array}{l}\text { : A } \\
: \text { Medium }\end{array}$ & $\begin{array}{l}\text { A } \\
\text { Medium }\end{array}$ & $\begin{array}{l}\text { A } \\
\text { Medium }\end{array}$ & \\
\hline
\end{tabular}

$\begin{array}{lll} & \text { Roof } 1 & \text { Roof } 2 \\ \text { Name } & : \text { WEST } & \text { NA } \\ \text { Area (ft2) } & : 3898 & \\ \text { U-Factor (BTUH/ft2-deg F) } & : .124 & \\ \text { Roof construction code } & : 8 \\ \text { Color correction } & : \text { Dark } \\ \text { Suspended ceiling plenum } & : \text { Yes }\end{array}$


WINDOW DATA FOR ZONE 1 - WEST DINING AREA, SNACK

$\begin{array}{lllll} & \text { Window } 1 & \text { Window 2 } & \text { Window } 3 & \text { Window } 4 \\ \text { Name } & : \mathrm{S} & W & \text { NA } & \text { NA } \\ \text { Window orientation } & : \text { South } & \text { West } & & \\ \text { Fenestration area (ft2) } & \vdots 130 & 263 & & \\ \text { Shading coefficient } & \vdots .64 & 1.64 & \\ \text { U-Factor (BTUH/ft2-deg F) } & : 1.01 & 1.01 & \\ \text { Space mass code } & : \text { Heavy } & \text { Heavy } & \\ \text { Crack length (lin ft) } & : 0 & 0 & \\ \text { Leakage coefficient } & : 0 & 0 & \\ \text { Inputs Required for Shading } & & & \\ \text { Window shading model number } & : 0 & 0 & \end{array}$

INFILTRATION OATA FOR ZONE 1 - WEST DINING AREA, SNACK

Occupied air change rate: : 0 air changes per hour

Unoccupied air change rate : 0 air changes per hour

MISCELLANEOUS CONOUCTION FOR ZONE 1 - WEST DIMING AREA, SNACK

$\begin{array}{lll} & \text { Type } 1 & \text { Type 2: } \\ \text { Name } & : \text { from kitchen } & \text { from dishwa } \\ \text { Area (ft2) } & : 348 & 430 \\ \text { U-Factor (BTUH/ft2-deg F) } & : 0.31 & 0.31 \\ \text { Ref temperature at design sumer (deg F) } 85 & 78 \\ \text { Ref temperature at design winter (deg F): } 82 & 78\end{array}$




\begin{tabular}{|c|c|c|c|c|}
\hline People & - Avg $\%$ of full occupancy & $\begin{array}{l}\text { Occupied } \\
\text { Period } \\
: \quad 34\end{array}$ & $\begin{array}{l}\text { Unoccupied } \\
\text { Period } \\
0\end{array}$ & $\begin{array}{l}\text { Month Sched } \\
\text { Table } \#(1-4) \\
1\end{array}$ \\
\hline $\begin{array}{l}\text { Lights } \\
\text { DINING } \\
\text { BATHROOM } \\
\text { VESTIBULE } \\
\text { NA }\end{array}$ & $\begin{array}{l}\text { - Avg } \% \text { of installed capacity } \\
\text { - Avg } \% \text { of installed capacity } \\
\text { - Avg } \% \text { of installed capacity } \\
\text { - Avg } \% \text { of installed capacity }\end{array}$ & $\begin{array}{l}: \quad 50.4 \\
: \quad 50.4 \\
: \quad 50.4\end{array}$ & $\begin{array}{l}47.9 \\
47.9 \\
47.9\end{array}$ & $\begin{array}{l}4 \\
4 \\
4\end{array}$ \\
\hline $\begin{array}{l}\text { Electric Equif } \\
\text { SER-UNHOODED } \\
\text { SER-HOODED }\end{array}$ & $\begin{array}{l}\text { pment } \\
\text { - Avg } \% \text { of installed capacity } \\
\text { - Avg } \% \text { of installed capacity }\end{array}$ & $\begin{array}{l}: \quad 36.3 \\
: \quad 36.3\end{array}$ & $\begin{array}{l}22.0 \\
22.0\end{array}$ & $\begin{array}{l}3 \\
3\end{array}$ \\
\hline $\begin{array}{l}\text { Hiscellaneous } \\
\text { NA } \\
\text { NA }\end{array}$ & $\begin{array}{l}\text { Sensible Loads } \\
\text { - Avg } \% \text { of installed capacity } \\
\text { - Avg } \% \text { of installed capacity }\end{array}$ & : & & \\
\hline
\end{tabular}




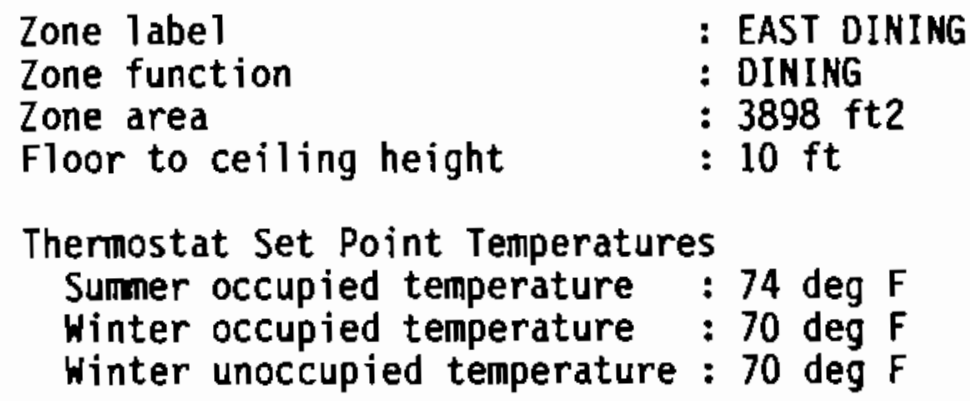

Thermostat Set Point Temperatures

Sumer occupied temperature : $74 \mathrm{deg} F$ Winter occupied temperature : $70 \mathrm{deg} F$ Winter unoccupied temperature : $70 \mathrm{deg} F$

LIGHTING DATA FOR ZONE 2 - EAST DINING

Ltg Func 1 Ltg Func 2 Ltg Func 3 Ltg Func 4

\begin{tabular}{|c|c|c|}
\hline $\begin{array}{l}\text { Function name } \\
\text { Function area }(\mathrm{ft} 2)\end{array}$ & $\begin{array}{l}: \text { DINING } \\
: 3748\end{array}$ & $\begin{array}{l}\text { BATHROOM } \\
100\end{array}$ \\
\hline $\begin{array}{l}\text { Installed watts } / \mathrm{ft} 2 \\
\text { (times) Percent function area } \\
\text { Total installed watts }\end{array}$ & $\begin{array}{l}: \\
\vdots \\
:\end{array} 8178$ & 204 \\
\hline Daylighting analysis & : No & No \\
\hline $\begin{array}{l}\text { Lighting system type } \\
\text { Percent light heat to space } \\
\text { A' Classification } \\
\text { 'B' Classification }\end{array}$ & $\begin{array}{l}: 80 \\
:=55 \\
: c^{-55}\end{array}$ & $\begin{array}{l}80 \\
i^{55}\end{array}$ \\
\hline $\begin{array}{l}\text { Diversity factors - occupied } \\
\text { Diversity factors - unoccupied } \\
\text { Monthly diversity table number }\end{array}$ & $\begin{array}{l}: 63.0 \\
: 59.2 \\
: 4\end{array}$ & $\begin{array}{l}63.0 \\
59.2 \\
4\end{array}$ \\
\hline
\end{tabular}

PEOPLE DATA FOR ZONE 2 - EAST DINING

$\begin{array}{ll}\text { Number of people in zone } & : 150 \\ \text { Sensible load per person } & : 255 \text { BTUH per person } \\ \text { Latent load per person } & : 325 \text { BTUH per person } \\ \text { Diversity factor - occupied } & : 34 \\ \text { Oiversity factor - unoccupied } & : 0 \\ \text { Monthly diversity table number } & : 1\end{array}$




\begin{tabular}{|c|c|c|c|c|}
\hline & Type 1 & & Type 2 & \\
\hline $\begin{array}{l}\text { Electric equipment name } \\
\text { Total installed watts } \\
\text { Hooded }\end{array}$ & $\begin{array}{l}: \text { SER UNHOODE } \\
: 14300 \\
: \text { No }\end{array}$ & & $\begin{array}{l}\text { SER HOODED } \\
10700 \\
\text { Yes }\end{array}$ & \\
\hline $\begin{array}{l}\text { Diversity factors - occupied } \\
\text { Diversity factors - unoccupied } \\
\text { Monthly diversity table number }\end{array}$ & $\begin{array}{l}: 36.3 \\
: 22.0 \\
: 3\end{array}$ & & $\begin{array}{l}36.3 \\
22.0 \\
3\end{array}$ & \\
\hline \multicolumn{5}{|c|}{ WALL DATA FOR ZONE 2 - EAST DINING } \\
\hline 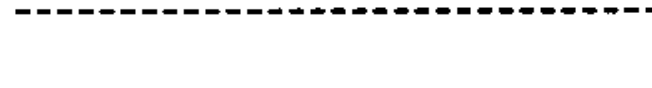 & Wall 1 & Wall 2 & Wall 3 & Wall 4 \\
\hline Name & $: N$ & $\mathbf{E}$ & 5 & NA \\
\hline $\begin{array}{l}\text { Wall orientation } \\
\text { Area (ft2) } \\
\text { U-Factor (BTUH/ft2-deg F) }\end{array}$ & $\begin{array}{l}: \text { North } \\
: 202 \\
: .111\end{array}$ & $\begin{array}{l}\text { East } \\
727 \\
.111\end{array}$ & $\begin{array}{l}\text { South } \\
635 \\
.111\end{array}$ & \\
\hline $\begin{array}{l}\text { Wall construction group } \\
\text { Color correction }\end{array}$ & $\begin{array}{l}: \text { A } \\
: \text { Medium }\end{array}$ & $\begin{array}{l}\text { A } \\
\text { Medium }\end{array}$ & $\begin{array}{l}\text { A } \\
\text { Medium }\end{array}$ & \\
\hline \multicolumn{5}{|c|}{ ROOF DATA FOR ZONE 2 - EAST DINING } \\
\hline & Roof 1 & & Roof 2 & \\
\hline Name & : EAST & & NA & \\
\hline $\begin{array}{l}\text { Area (ft2) } \\
\text { U-Factor (BTUH/ft2-deg F) }\end{array}$ & $\begin{array}{l}: 3898 \\
: .124\end{array}$ & & & \\
\hline $\begin{array}{l}\text { Roof construction code } \\
\text { Color correction }\end{array}$ & $\begin{array}{l}: 8 \\
: \text { Dark }\end{array}$ & & & \\
\hline Suspended ceiling plenum & : Yes & & & \\
\hline
\end{tabular}




\begin{tabular}{|c|c|c|c|c|}
\hline & Window 1 & Window 2 & Window 3 & Window 4 \\
\hline Name & $E$ & $S$ & NA & NA \\
\hline $\begin{array}{l}\text { Window orientation } \\
\text { Fenestration area (ft2) } \\
\text { Shading coefficient } \\
\text { U-Factor (BTUH/ft2-deg F) } \\
\text { Space mass code } \\
\text { Crack length ( } 1 \text { in } \mathrm{ft} \text { ) } \\
\text { Leakage coefficient }\end{array}$ & $\begin{array}{l}\text { East } \\
263 \\
.64 \\
1.01 \\
\text { Heavy } \\
0 \\
0\end{array}$ & $\begin{array}{l}\text { South } \\
130 \\
.64 \\
1.01 \\
\text { Heavy } \\
0 \\
0\end{array}$ & & \\
\hline \multicolumn{5}{|l|}{ Inputs Required for Shading } \\
\hline $\begin{array}{l}\text { Window shading model number } \\
\text { Percent window area }\end{array}$ & 0 & 0 & & \\
\hline \multicolumn{5}{|c|}{ INFILTRATION DATA FOR ZONE 2 - EAST DINING } \\
\hline $\begin{array}{l}\text { Occupied air change rate } \\
\text { Unoccupied air change rate }\end{array}$ & $\begin{array}{l}0 \text { air ch } \\
0 \text { air ch }\end{array}$ & $\begin{array}{l}\text { iges per ho } \\
\text { iges per ho }\end{array}$ & & \\
\hline \multicolumn{5}{|c|}{ MISCELLANEOUS CONDUCTION FOR ZONE 2 - EAST DINING } \\
\hline & \multicolumn{2}{|c|}{ Type 1} & \multicolumn{2}{|r|}{ Type 2: } \\
\hline $\begin{array}{l}\text { Name } \\
\text { Area (ft2) } \\
\text { U-Factor (BTUH/ft2-deg F) } \\
\text { Ref temperature at design summer } \\
\text { Ref temperature at design winter }\end{array}$ & \multicolumn{2}{|c|}{$\begin{aligned}: & \text { from kitchen } \\
: & 70 \\
: & 0.31 \\
\text { eg F) } & : 85 \\
\text { eg F) }: & 82\end{aligned}$} & \multicolumn{2}{|r|}{$\begin{array}{l}\text { from dishwi } \\
430 \\
0.31 \\
78 \\
78\end{array}$} \\
\hline
\end{tabular}




\begin{tabular}{|c|c|c|c|c|}
\hline People & - Avg $\%$ of full occupancy & $\begin{array}{l}\text { Occupied } \\
\text { Period } \\
: \quad 34\end{array}$ & $\begin{array}{l}\text { Unoccupied } \\
\text { Period } \\
0\end{array}$ & $\begin{array}{l}\text { Month Sched } \\
\text { Table } \#(1-4) \\
1\end{array}$ \\
\hline $\begin{array}{l}\text { Lights } \\
\text { DINING } \\
\text { BATHROOH } \\
\text { VESTIBULE } \\
\text { NA }\end{array}$ & $\begin{array}{l}\text { - Avg } \% \text { of installed capacity } \\
\text { - Avg } \% \text { of installed capacity } \\
\text { - Avg } \% \text { of installed capacity } \\
\text { - Avg } \% \text { of installed capacity }\end{array}$ & $\begin{array}{l}: \quad 63.0 \\
: \quad 63.0 \\
: \quad 63.0\end{array}$ & $\begin{array}{l}59.2 \\
59.2 \\
59.2\end{array}$ & $\begin{array}{l}4 \\
4 \\
4\end{array}$ \\
\hline $\begin{array}{l}\text { Electric Equip } \\
\text { SER UNHOODED } \\
\text { SER HOODED }\end{array}$ & $\begin{array}{l}\text { Pment } \\
\text { - Avg } \% \text { of installed capacity } \\
\text { - Avg } \% \text { of installed capacity }\end{array}$ & $\begin{array}{l}: \quad 36.3 \\
: \quad 36.3\end{array}$ & $\begin{array}{l}22.0 \\
22.0\end{array}$ & $\begin{array}{l}3 \\
3\end{array}$ \\
\hline $\begin{array}{l}\text { Miscellaneous } \\
\text { NA } \\
\text { NA }\end{array}$ & $\begin{array}{l}\text { Sensible Loads } \\
\text { - Avg \& of installed capacity } \\
\text { - Avg } \% \text { of installed capacity }\end{array}$ & : & & \\
\hline
\end{tabular}




$\begin{array}{ll}\text { Zone label } & : \text { DISHWASHER } \\ \text { Zone function } & : \text { SANITATION } \\ \text { Zone area } & : 837 \mathrm{ft} 2 \\ \text { Floor to ceiling height } & : 10 \mathrm{ft}\end{array}$

Thermostat Set Point Temperatures

Summer occupied temperature : 78 deg F

Winter occupied temperature : $78 \mathrm{deg} F$

Winter unoccupied temperature : $78 \mathrm{deg} F$

LIGHTING DATA FOR ZONE 3 - DISHWASHER

Ltg Func 1 Ltg Func 2 Ltg Func 3 Ltg Func 4

\begin{tabular}{|c|c|c|c|}
\hline $\begin{array}{l}\text { Function name } \\
\text { Function area (ft2) }\end{array}$ & $\begin{array}{l}: \text { D WASH } \\
: 8 \overline{3} 7\end{array}$ & NA & NA \\
\hline $\begin{array}{l}\text { Installed watts } / \mathrm{ft} 2 \\
\text { (times) Percent function area } \\
\text { Total installed watts }\end{array}$ & $\begin{array}{l}: \\
: \\
:\end{array} 1152$ & & \\
\hline Daylighting analysis & : No & & \\
\hline $\begin{array}{l}\text { Lighting system type } \\
\text { Percent light heat to space } \\
\text { A' Classification }^{\prime} \\
\text { 'B' Classification }\end{array}$ & $\begin{array}{l}: F L \\
: 80 \\
:: 55 \\
: \quad .5\end{array}$ & & \\
\hline $\begin{array}{l}\text { Diversity factors - occupied } \\
\text { Diversity factors - unoccupied } \\
\text { Monthly diversity table number }\end{array}$ & $\begin{array}{l}: 94.8 \\
: \\
: 49.1 \\
:\end{array}$ & & \\
\hline
\end{tabular}

PEOPLE DATA FOR ZONE 3 - DISHWASHER

Number of people in zone : 3

Sensible load per person : 345 BTUH per person

Latent load per person : 435 BTUH per person

Diversity factor - occupied : 50

Diversity factor - unoccupied : 0

Monthly diversity table number : 2 


\begin{tabular}{|c|c|c|}
\hline & Type 1 & Type 2 \\
\hline $\begin{array}{l}\text { Electric equipment name } \\
\text { Total installed watts } \\
\text { Hooded }\end{array}$ & $\begin{array}{l}: \text { HOODED } \\
: 53700 \\
: \text { Yes }\end{array}$ & NA \\
\hline $\begin{array}{l}\text { Diversity factors - occupied } \\
\text { Diversity factors - unoccupied } \\
\text { Monthly diversity table number }\end{array}$ & $\begin{array}{l}: 36.3 \\
: 22.0 \\
: 3\end{array}$ & \\
\hline \multicolumn{3}{|c|}{ ROOF DATA FOR ZONE 3 - DISHWASHER } \\
\hline & Roof 1 & Roof 2 \\
\hline Name & : D_WASH & NA \\
\hline $\begin{array}{l}\text { Area (ft2) } \\
\text { U-Factor (BTUH/ft2-deg F) }\end{array}$ & $\begin{array}{l}: 837 \\
: .124\end{array}$ & \\
\hline $\begin{array}{l}\text { Roof construction code } \\
\text { Color correction }\end{array}$ & $\begin{array}{l}\text { : } 8 \\
\text { : Dark }\end{array}$ & \\
\hline Suspended ceiling plenum & : Yes & \\
\hline
\end{tabular}

Occupied air change rate : 0 air changes per hour

Unoccupied air change rate : 0 air changes per hour

MISCELLANEOUS CONDUCTION FOR ZONE 3 - DISHWASHER

\begin{tabular}{|c|c|c|}
\hline & Type 1 & Type 2: \\
\hline $\begin{array}{l}\text { Name } \\
\text { Area (ft2) } \\
\text { U-Factor (BTUH/ft2-deg F) } \\
\text { Ref temperature at design s } \\
\text { Ref temperature at design }\end{array}$ & $\begin{aligned} & : \text { to zone1 } \\
: & 430 \\
: & 0.31 \\
\text { summer }(\operatorname{deg} F): & 74 \\
\text { winter }(\operatorname{deg} F): & 70\end{aligned}$ & $\begin{array}{l}\text { to zone2 } \\
430 \\
0.31 \\
74 \\
70\end{array}$ \\
\hline
\end{tabular}




\begin{tabular}{|c|c|c|c|c|}
\hline People & - Avg $\%$ of full occupancy & $\begin{array}{l}\text { Occupied } \\
\text { Period } \\
: \quad 50\end{array}$ & $\begin{array}{l}\text { Unoccupied } \\
\text { Period } \\
0\end{array}$ & $\begin{array}{l}\text { Month Sched } \\
\text { Table }(1-4) \\
2\end{array}$ \\
\hline $\begin{array}{l}\text { Lights } \\
\text { D WASH } \\
\text { NA } \\
\text { NA } \\
\text { NA }\end{array}$ & $\begin{array}{l}\text { - Avg } \% \text { of installed capacity } \\
\text { - Avg } \% \text { of installed capacity } \\
\text { - Avg } \% \text { of installed capacity } \\
\text { - Avg } \% \text { of installed capacity }\end{array}$ & $\begin{array}{l}: \\
:\end{array}$ & 89.1 & 4 \\
\hline $\begin{array}{l}\text { Electric Equip } \\
\text { HOODED } \\
\text { NA }\end{array}$ & $\begin{array}{l}\text { pment } \\
\text { - Avg } \% \text { of installed capacity } \\
\text { - Avg } \% \text { of installed capacity }\end{array}$ & $: 36.3$ & 22.0 & 3 \\
\hline $\begin{array}{l}\text { Miscellaneous } \\
\text { NA } \\
\text { NA }\end{array}$ & $\begin{array}{l}\text { Sensible Loads } \\
\text { - Avg } \% \text { of installed capacity } \\
\text { - Avg } \% \text { of installed capacity }\end{array}$ & : & & \\
\hline
\end{tabular}




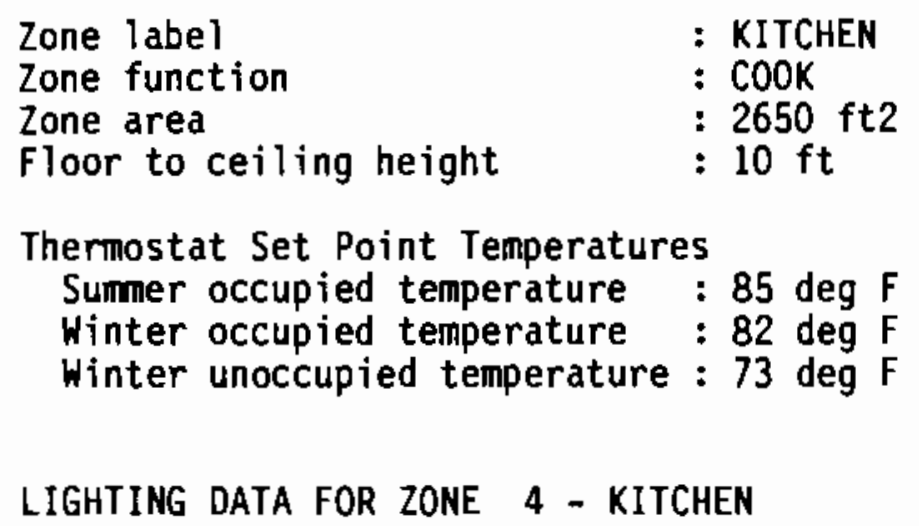

Thermostat Set Point Temperatures Summer occupied temperature : $85 \mathrm{deg} F$ Winter occupied temperature : $82 \operatorname{deg} \mathrm{F}$ Winter unoccupied temperature : $73 \operatorname{deg} F$

LIGHTING DATA FOR ZONE 4 - KITCHEN

Ltg Func 1 Ltg Func 2 Ltg Func 3 Ltg Func 4

$\begin{array}{lll}\text { Function name } & : K & \text { NA } \\ \text { Function area (ft2) } & : 2650 \\ \text { Installed watts/ft2 } & : \\ \text { (times) Percent function area } & : \\ \text { Total installed watts } & : 6072 \\ \text { Daylighting analysis } & : \text { No } \\ \text { Lighting system type } & : \text { FL } \\ \text { Percent light heat to space } & : 80 \\ \text { 'A' Classification } & : .55 \\ \text { 'B' Classification } & : C \\ \text { Diversity factors - occupied } & : 83.8 \\ \text { Diversity factors - unoccupied } & : 78.9 \\ \text { Monthiy diversity table number } & : 4\end{array}$

PEOPLE DATA FOR ZONE 4 - KITCHEN
Number of people in zone
Sensible load per person
Latent load per person
$: 10$
: 345 BTUH per person
: 435 BTUH per person
Diversity factor - occupied : 100
Diversity factor - unoccupied : 0
Monthly diversity table number : 2 


\begin{tabular}{|c|c|c|c|c|}
\hline & Type 1 & & Type 2 & \\
\hline $\begin{array}{l}\text { Electric equipment name } \\
\text { Total installed watts } \\
\text { Hooded }\end{array}$ & $\begin{array}{l}: \text { HOODED } \\
: 75900 \\
: \text { Yes }\end{array}$ & & $\begin{array}{l}\text { UN-HOODED } \\
8530 \\
\text { No }\end{array}$ & \\
\hline $\begin{array}{l}\text { Diversity factors - occupied } \\
\text { Diversity factors - unoccupied } \\
\text { Monthiy diversity table number }\end{array}$ & $\begin{array}{l}: 36.3 \\
: 22.0 \\
: 3\end{array}$ & & $\begin{array}{l}36.3 \\
22.0 \\
3\end{array}$ & \\
\hline \multicolumn{5}{|l|}{ WALL DATA FOR ZONE 4 - KITCHEH } \\
\hline & Wall 1 & Wall 2 & Wa?13 & Wall 4 \\
\hline Name & $: W$ & $\mathbf{N}$ & NA & NA \\
\hline $\begin{array}{l}\text { Wall orientation } \\
\text { Area (ft2) } \\
\text { U-Factor (BTUH/ft2-deg F) }\end{array}$ & $\begin{array}{l}: \text { West } \\
: 563 \\
: .111\end{array}$ & $\begin{array}{l}\text { North } \\
303 \\
.111\end{array}$ & & \\
\hline $\begin{array}{l}\text { Wall construction group } \\
\text { Color correction }\end{array}$ & $\begin{array}{l}\text { : A } \\
: \text { Medium }\end{array}$ & $\begin{array}{l}\text { A } \\
\text { Medium }\end{array}$ & Medium & \\
\hline \multicolumn{5}{|l|}{ ROOF DATA FOR ZONE 4 - KITCHEN } \\
\hline & Roof 1 & & Roof 2 & \\
\hline Name & : KITCHEN & & NA & \\
\hline $\begin{array}{l}\text { Area (ft2) } \\
\text { U-Factor (BTUH/ft2-deg F) }\end{array}$ & $\begin{array}{l}: 2650 \\
: .124\end{array}$ & & & \\
\hline $\begin{array}{l}\text { Roof construction code } \\
\text { Color correction }\end{array}$ & $\begin{array}{l}: 8 \\
: \text { Dark }\end{array}$ & & & \\
\hline Suspended ceiling plenum & : Yes & & & \\
\hline \multicolumn{5}{|c|}{ INFILTRATION DATA FOR ZONE 4 - KITCHEN } \\
\hline $\begin{array}{l}\text { Occupied air change rate } \\
\text { Unoccupied air change rate }\end{array}$ & $\begin{array}{l}: 0.00 \text { air } \\
: 0 \text { air ch }\end{array}$ & $\begin{array}{l}\text { hanges } p \\
\text { ges per }\end{array}$ & $\begin{array}{l}r \text { hour } \\
\text { our }\end{array}$ & \\
\hline
\end{tabular}




\section{Type 1}

Name

Area (ft2)

U-Factor (BTUH/ft2-deg F)

Ref temperature at design

Ref temperature at design winter (deg F): 70
Type 2:

to zone 5

408

.031

74

$\begin{array}{ll}: \text { to zones } 1267 & \text { to } \\ : 1186 & 408 \\ : 0.31 & .03 \\ : 74 & 74 \\ : 70 & 70\end{array}$

OPERATING USE PROFILE (DIVERSITY) DATA

\begin{tabular}{|c|c|c|c|c|}
\hline People & - Avg \% of full occupancy & $\begin{array}{l}\text { Occupied } \\
\text { Period } \\
: \quad 100\end{array}$ & $\begin{array}{l}\text { Unoccupied } \\
\text { Period } \\
0\end{array}$ & $\begin{array}{l}\text { Month Sched } \\
\text { Table } \\
2\end{array}$ \\
\hline $\begin{array}{l}\text { Lights } \\
K \\
\text { NA } \\
\text { NA } \\
\text { NA }\end{array}$ & $\begin{array}{l}\text { - Avg } \& \text { of installed capacity } \\
\text { - Avg } \% \text { of installed capacity } \\
\text { - Avg } \% \text { of installed capacity } \\
\text { - Avg } \% \text { of installed capacity }\end{array}$ & $\begin{array}{l}: \\
:\end{array}$ & 78.9 & 4 \\
\hline $\begin{array}{l}\text { Electric Equip } \\
\text { HOODED } \\
\text { UN-HOODED }\end{array}$ & $\begin{array}{l}\text { pment } \\
\text { - Avg } \% \text { of installed capacity } \\
\text { - Avg } \% \text { of installed capacity }\end{array}$ & $\begin{array}{l}: \quad 36.3 \\
: \quad 36.3\end{array}$ & $\begin{array}{l}22.0 \\
22.0\end{array}$ & $\begin{array}{l}3 \\
3\end{array}$ \\
\hline $\begin{array}{l}\text { Miscellaneous } \\
\text { NA } \\
\text { NA }\end{array}$ & $\begin{array}{l}\text { Sensible Loads } \\
\text { - Avg } \% \text { of installed capacity } \\
\text { - Avg } \% \text { of installed capacity }\end{array}$ & $:$ & & \\
\hline
\end{tabular}


Zone label

Zone function

Zone area

Floor to ceiling height
: STORAGE

: STORAGE

: $970 \mathrm{ft} 2$

$: 10 \mathrm{ft}$

Thermostat Set Point Temperatures

Summer occupied temperature : $74 \mathrm{deg} F$

Winter occupied temperature : $70 \mathrm{deg} F$

Winter unoccupied temperature : $70 \mathrm{deg} F$

LIGHTING DATA FOR ZONE 5 - STORAGE

Function name

Function area (ft2)
Ltg Func $1 \mathrm{Ltg}$ Func 2 Ltg Func 3 Ltg Func 4

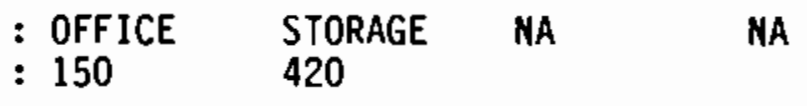

Installed watts/ft2

(times) Percent function area:

Total installed watts

Daylighting analysis

Lighting system type

Percent light heat to space :

' $A^{\prime}$ Classification

' $B$ ' Classification

Diversity factors - occupied : 41.4

Diversity factors - unoccupied : 33.6

Monthly diversity table number : 4

\section{: $336 \quad 636$}

: No No

$80 \quad 80$

$: .55 \quad .55$

$: \dot{c} \quad \dot{c}$

41.4

33.6

4

PEOPLE DATA FOR ZONE 5 - STORAGE

Number of people in zone : 2

Sensible load per person : 255 BTUH per person

Latent load per person : 255 BTUH per person

Diversity factor - occupied : 100

Diversity factor - unoccupied : 0

Monthly diversity table number : 2 


\section{Type 1}

Electric equipment name

Total installed watts

Hooded

Diversity factors - occupied

Diversity factors - unoccupied

Monthly diversity table number
: OFFICE

$: 0$

: No

$: 36.3$

$: 22.0$

: 3
Type 2

refrigeration

10600

No

36.3

22.0

3

WALL DATA FOR ZONE 5 - STORAGE

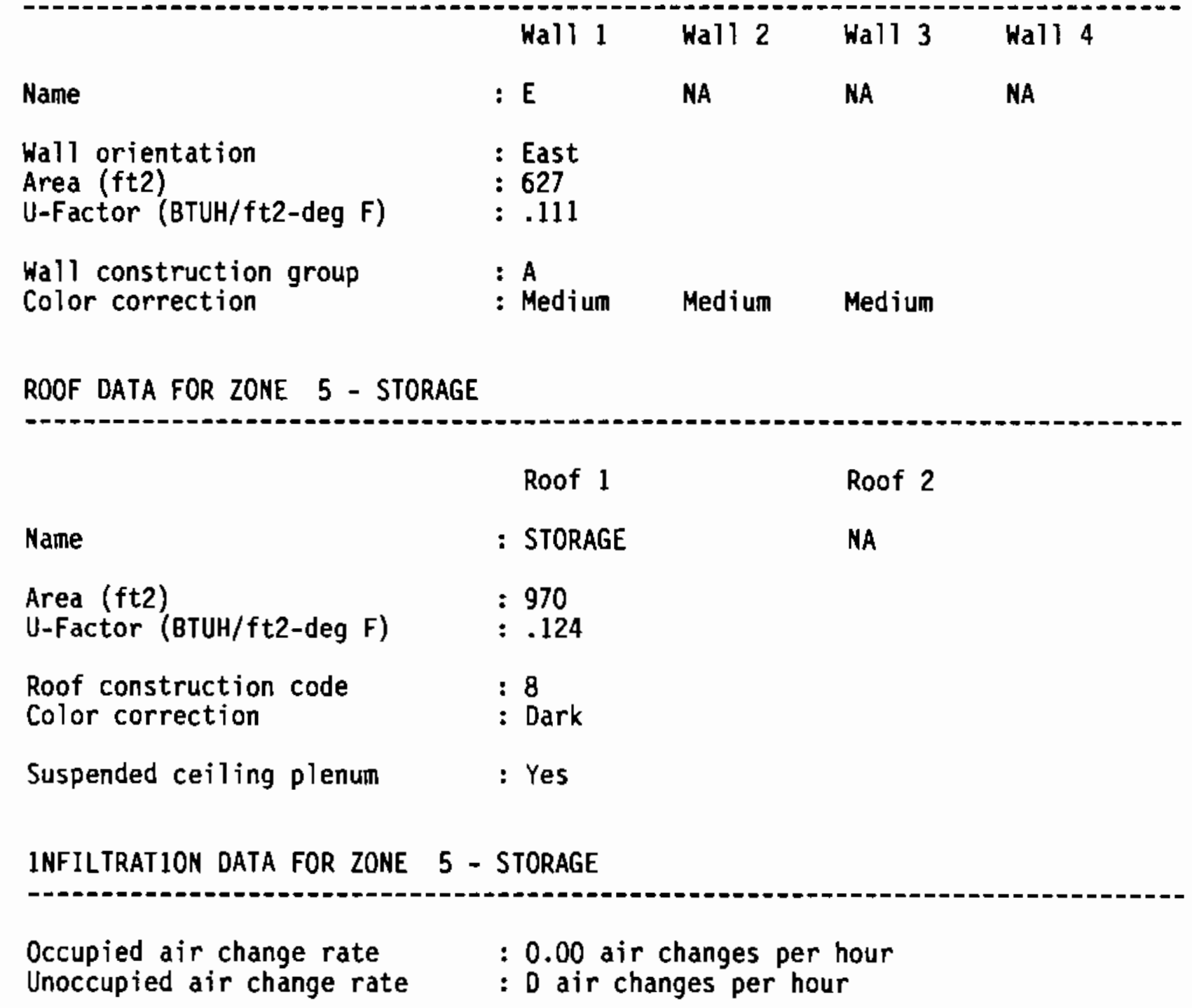


OPERATING USE PROFILE (DIVERSITY) DATA

\begin{tabular}{|c|c|c|c|c|}
\hline People & - Avg of of full occupancy & $\begin{array}{l}\text { Occupied } \\
\text { Period } \\
: \quad 100\end{array}$ & $\begin{array}{l}\text { Unoccupied } \\
\text { Period } \\
0\end{array}$ & $\begin{array}{l}\text { Month Sched } \\
\text { Table } \#(1-4) \\
2\end{array}$ \\
\hline $\begin{array}{l}\text { Lights } \\
\text { OFFICE } \\
\text { STORAGE } \\
\text { NA } \\
\text { NA }\end{array}$ & $\begin{array}{l}\text { - Avg } \% \text { of installed capacity } \\
\text { - Avg } \% \text { of installed capacity } \\
\text { - Avg } \% \text { of installed capacity } \\
\text { - Avg } \% \text { of installed capacity }\end{array}$ & 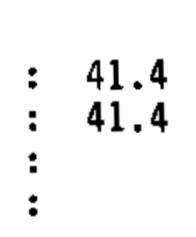 & $\begin{array}{l}33.6 \\
33.6\end{array}$ & $\begin{array}{l}4 \\
4\end{array}$ \\
\hline $\begin{array}{l}\text { Electric Equip } \\
\text { OFFICE } \\
\text { refrigeration }\end{array}$ & $\begin{array}{l}\text { pment } \\
\text { - Avg } \% \text { of installed capacity } \\
\text { - Avg } \% \text { of installed capacity }\end{array}$ & $\begin{array}{l}: \quad 36.3 \\
: \quad 36.3\end{array}$ & $\begin{array}{l}22.0 \\
22.0\end{array}$ & $\begin{array}{l}3 \\
3\end{array}$ \\
\hline $\begin{array}{l}\text { Miscellaneous } \\
\text { NA } \\
\text { NA }\end{array}$ & $\begin{array}{l}\text { Sensible Loads } \\
\text { - Avg } \% \text { of installed capacity } \\
\text { - Avg } \% \text { of installed capacity }\end{array}$ & : & & \\
\hline
\end{tabular}


ZONE DATA FOR ZONE 6 - OFFICE

$\begin{array}{ll}\text { Zone label } & : \text { OFFICE } \\ \text { Zone function } & : \text { OFFICE } \\ \text { Zorre area } & : 368 \mathrm{ft} 2 \\ \text { Floor to ceiling height } & : 10 \mathrm{ft}\end{array}$

Thermostat Set Point Temperatures Sumer occupied temperature : $74 \mathrm{deg} F$ Winter occupied temperature : 70 deg F Winter unoccupied temperature : 70 deg $\mathrm{F}$

LIGHTING DATA FOR ZONE 6 - OFFICE

Ltg Func $1 \mathrm{Ltg}$ Func 2 Ltg Func $3 \mathrm{Ltg}$ Func 4

Function name : OFFICE VESTIBULE NA NA

Function area $(\mathrm{ft} 2)$

: $265 \quad 123$

Installed watts/ft2 :

(times) Percent function area :

Total installed watts

$1504 \quad 634$

Daylighting analysis : No No

Lighting system type :

Percent light heat to space : $80 \quad 80$

'A' Classification $\quad: .55 \quad .55$

' $B$ ' Classification : $\mathrm{C} \quad \mathrm{C}$

Diversity factors - occupied : $11.6 \quad 11.6$

Diversity factors - unoccupied : $11.1 \quad 11.1$

Monthly diversity table number : 4 4

PEOPLE DATA FOR ZONE 6 - OFFICE

Number of people in zone : 3

Sensible load per person : 255 BTUH per person

Latent load per person : 255 BTUH per person

Diversity factor - occupied : 100

Diversity factor - unoccupied : 0

Monthly diversity table number : 2 


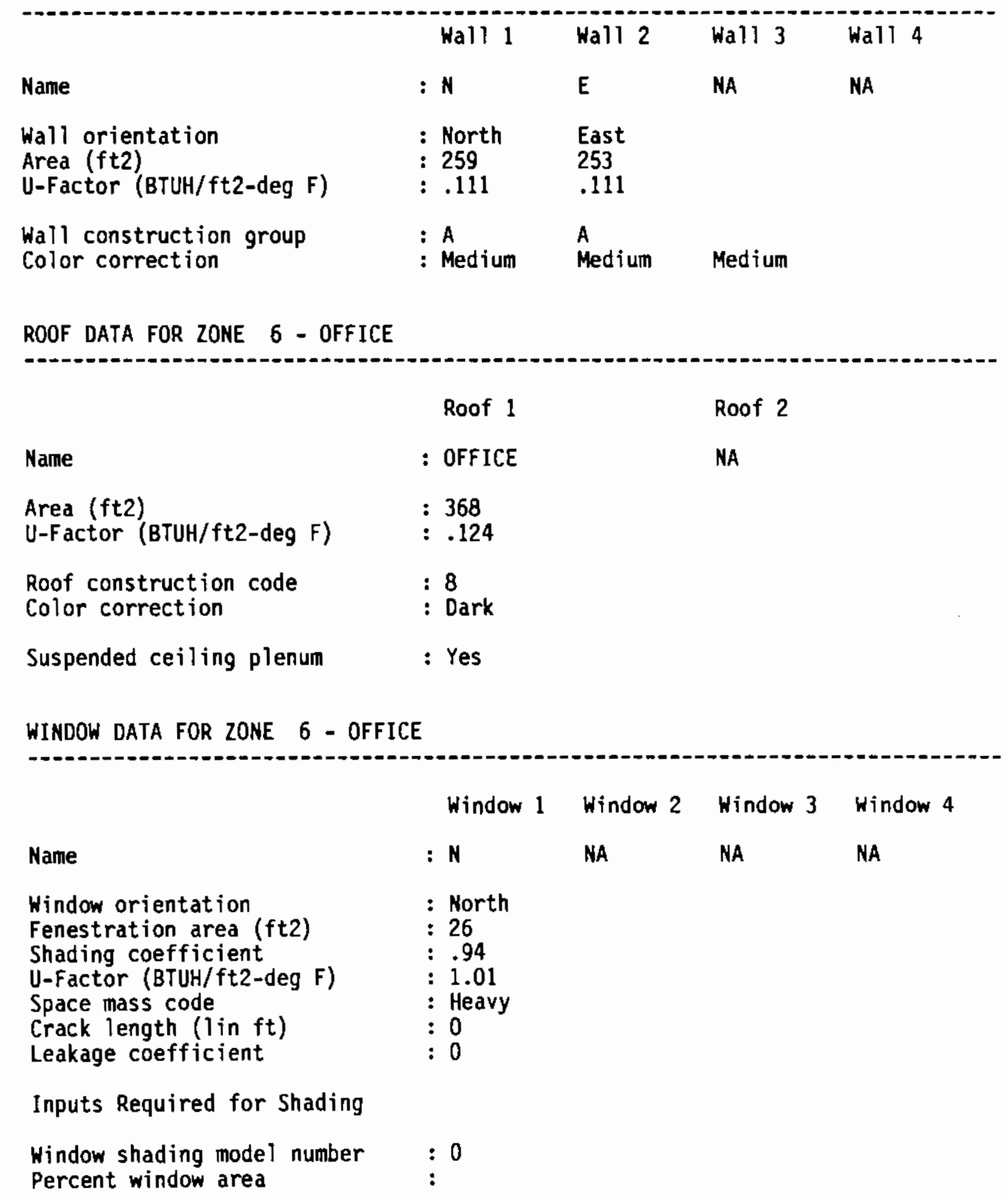


DOOR (EXTERNAL) DATA FOR ZONE 6 - OFFICE

$\begin{array}{lll} & \text { Type 1 } & \text { Type 2 } \\ \text { Name } & : \text { OFFICE } & \text { NA } \\ \text { Area (ft2) } & : 35 & \\ \text { U-Factor (BTUH/ft2-deg F) } & : 41 & \\ \text { Crack length (1in ft) } & : 25 & \\ \text { Leakage coefficient } & : 6\end{array}$

INFILTRATION DATA FOR ZONE 6 - OFFICE

Occupied air change rate : 0 air changes per hour

Unoccupied air change rate : 0 air changes per hour

MISCELLANEOUS CONDUCTION FOR ZONE 6 - OFFICE

\section{Type 1 Type 2:}

$\begin{array}{lll}\text { Name } & : \text { from kitchen } \\ \text { Area (ft2) } & : 325 \\ \text { U-Factor (BTUH/ft2-deg F) } & : 0.31 \\ \text { Ref temperature at design summer (deg F) } & : 85 \\ \text { Ref temperature at design winter (deg F) } & : 82\end{array}$

OPERATING USE PROFILE (DIVERS1TY) DATA

\begin{tabular}{|c|c|c|c|c|}
\hline People & - Avg $\%$ of full occupancy & $\begin{array}{l}\text { Occupied } \\
\text { Period } \\
: \quad 100\end{array}$ & $\begin{array}{l}\text { Unoccupied } \\
\text { Period } \\
0\end{array}$ & $\begin{array}{l}\text { Month Sched } \\
\text { Table \#(1-4) } \\
2\end{array}$ \\
\hline $\begin{array}{l}\text { Lights } \\
\text { OFFICE } \\
\text { VESTIBULE } \\
\text { NA } \\
\text { NA }\end{array}$ & $\begin{array}{l}\text { - Avg } \% \text { of installed capacity } \\
\text { - Avg } \% \text { of installed capacity } \\
\text { - Avg } \% \text { of installed capacity } \\
\text { - Avg } \% \text { of installed capacity }\end{array}$ & 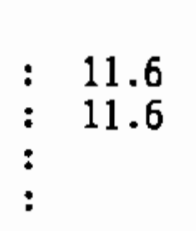 & $\begin{array}{l}11.1 \\
11.1\end{array}$ & $\begin{array}{l}4 \\
4\end{array}$ \\
\hline $\begin{array}{l}\text { Electric Equi } \\
\text { NA } \\
\text { NA }\end{array}$ & $\begin{array}{l}\text { pment } \\
\text { - Avg } \% \text { of installed capacity } \\
\text { - Avg } \% \text { of installed capacity }\end{array}$ & : & & \\
\hline $\begin{array}{l}\text { Miscellaneous } \\
\text { NA } \\
\text { NA }\end{array}$ & $\begin{array}{l}\text { Sensible Loads } \\
\text { - Avg } \% \text { of installed capacity } \\
\text { - Avg } \% \text { of installed capacity }\end{array}$ & : & & \\
\hline
\end{tabular}


Zone label

Zone function

Zone area

Floor to ceiling height
: EMPLOYEE

: LOCKER

: $816 \mathrm{ft} 2$

$: 10 \mathrm{ft}$

Thermostat Set Point Temperatures

Summer occupied temperature : $74 \mathrm{deg} F$

Winter occupied temperature : $70 \mathrm{deg} F$

Winter unoccupied temperature : $70 \mathrm{deg} F$

LIGHTING DATA FOR ZONE 7 - EMPLOYEE

Ltg Func $1 \mathrm{Ltg}$ Func $2 \mathrm{Ltg}$ Func $3 \mathrm{Ltg}$ Func 4

\begin{tabular}{|c|c|c|c|}
\hline $\begin{array}{l}\text { Function name } \\
\text { Function area (ft2) }\end{array}$ & $\begin{array}{l}: \text { BATHROOM } \\
: 562\end{array}$ & $\begin{array}{l}\text { HALLWAY } \\
254\end{array}$ & NA \\
\hline $\begin{array}{l}\text { Installed watts/ft2 } \\
\text { (times) Percent function area } \\
\text { Total installed watts }\end{array}$ & $\begin{array}{l}: \\
: \\
:\end{array} 860$ & 258 & \\
\hline Daylighting analysis & : No & No & \\
\hline $\begin{array}{l}\text { Lighting system type } \\
\text { Percent light heat to space } \\
\text { 'A' Classification } \\
\text { 'B' Classification }\end{array}$ & $\begin{array}{l}: \\
: 80 \\
: \quad .55 \\
:\end{array}$ & $\begin{array}{l}80 \\
.55\end{array}$ & \\
\hline $\begin{array}{l}\text { Diversity factors - occupied } \\
\text { Diversity factors - unoccupied } \\
\text { Monthly diversity table number }\end{array}$ & $\begin{array}{l}: 64.7 \\
: 65.8 \\
: 4\end{array}$ & $\begin{array}{l}64.7 \\
65.8 \\
4\end{array}$ & \\
\hline
\end{tabular}

PEOPLE DATA FOR ZONE 7 - EMPLOYEE

$\begin{array}{ll}\text { Number of people in zone } & : 10 \\ \text { Sensible load per person } & : 255 \text { BTUH per person } \\ \text { Latent load per person } & : 255 \text { BTUH per person } \\ & \\ \text { Diversity factor - occupied } & : 20 \\ \text { Diversity factor - unoccupied } & : 0 \\ \text { Monthly diversity table number } & : 2\end{array}$


WALL DATA FOR ZONE 7 - EMPLOYEE

\begin{tabular}{|c|c|c|c|c|}
\hline & Hall 1 & Wall 2 & Wall 3 & Wall 4 \\
\hline Name & $: N$ & $w$ & NA & NA \\
\hline $\begin{array}{l}\text { Wall orientation } \\
\text { Area (ft2) } \\
\text { U-Factor (BTUH/ft2-deg F) }\end{array}$ & $\begin{array}{l}: \text { North } \\
: 475 \\
: .111\end{array}$ & $\begin{array}{l}\text { West } \\
253 \\
.111\end{array}$ & & \\
\hline $\begin{array}{l}\text { Wall construction group } \\
\text { Color correction }\end{array}$ & $\begin{array}{l}: \text { A } \\
: \text { Medium }\end{array}$ & $\begin{array}{l}\text { A } \\
\text { Medium }\end{array}$ & Medium & \\
\hline \multicolumn{5}{|c|}{ ROOF DATA FOR ZONE 7 - EMPLOYEE } \\
\hline & Roof 1 & & Roof 2 & \\
\hline Name & : EMPLOYEE & & HA & \\
\hline $\begin{array}{l}\text { Area (ft2) } \\
\text { U-Factor (BTUH/ft2-deg F) }\end{array}$ & $\begin{array}{l}: 816 \\
: .124\end{array}$ & & & \\
\hline $\begin{array}{l}\text { Roof construction code } \\
\text { Color correction }\end{array}$ & $\begin{array}{l}: 8 \\
: \text { Dark }\end{array}$ & & & \\
\hline Suspended ceiling plenum & : Yes & & & \\
\hline
\end{tabular}

Window 1 Window 2 Window 3 Window 4

$\begin{array}{lllll}\text { Name } & \text { N } & \text { NA } & \text { NA } & \text { NA }\end{array}$

Window orientation

Fenestration area ( $\mathrm{ft} 2) \quad: 15$

Shading coefficient $\quad: .94$

U-Factor (BTUH/ft2-deg F) : 1.01

Space mass code

Crack length (lin $\mathrm{ft}$ )

Leakage coefficient

: Heavy

$: 0$

$: 0$

Inputs Required for Shading

Window shading model number $\quad: 0$

Percent window area 


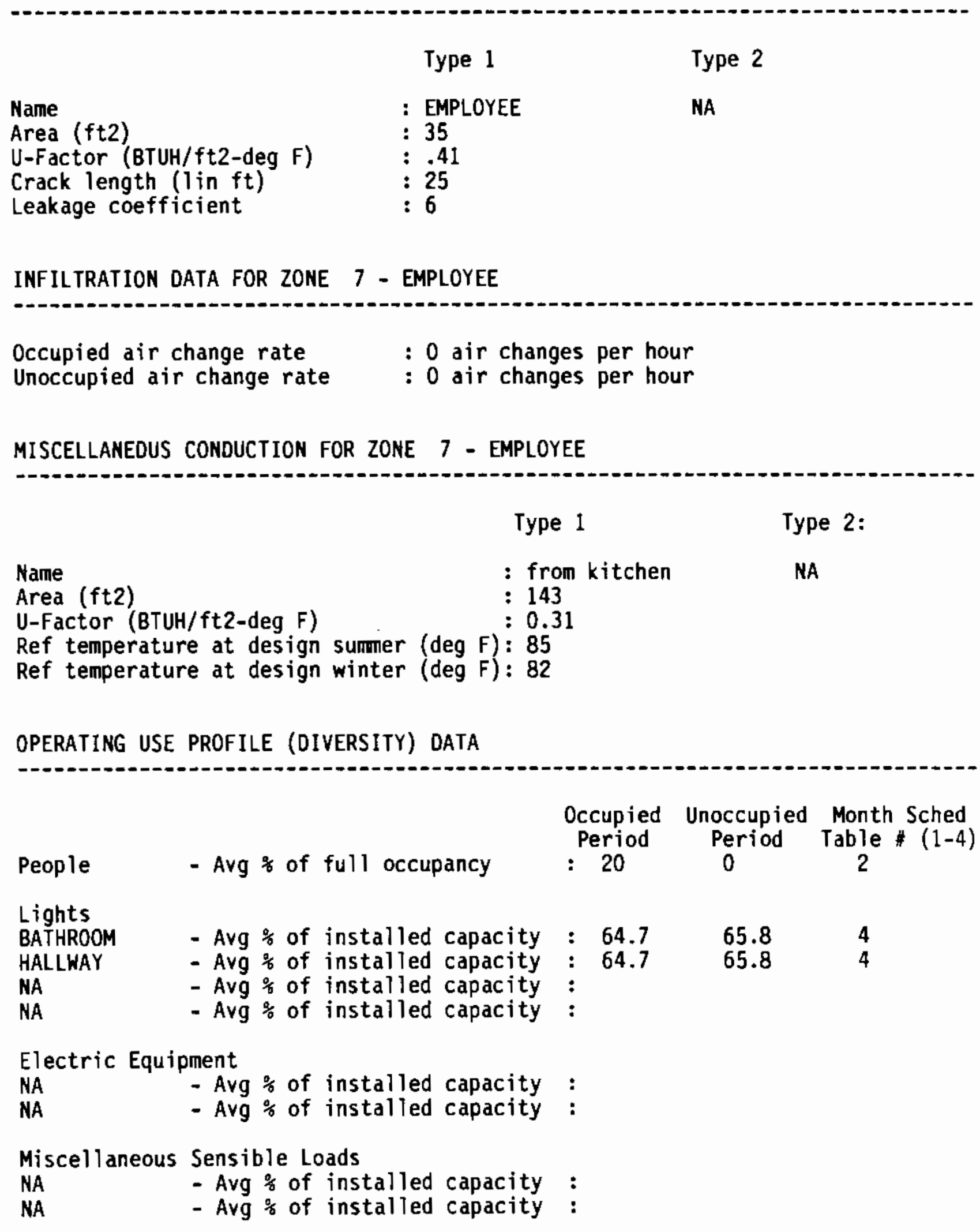




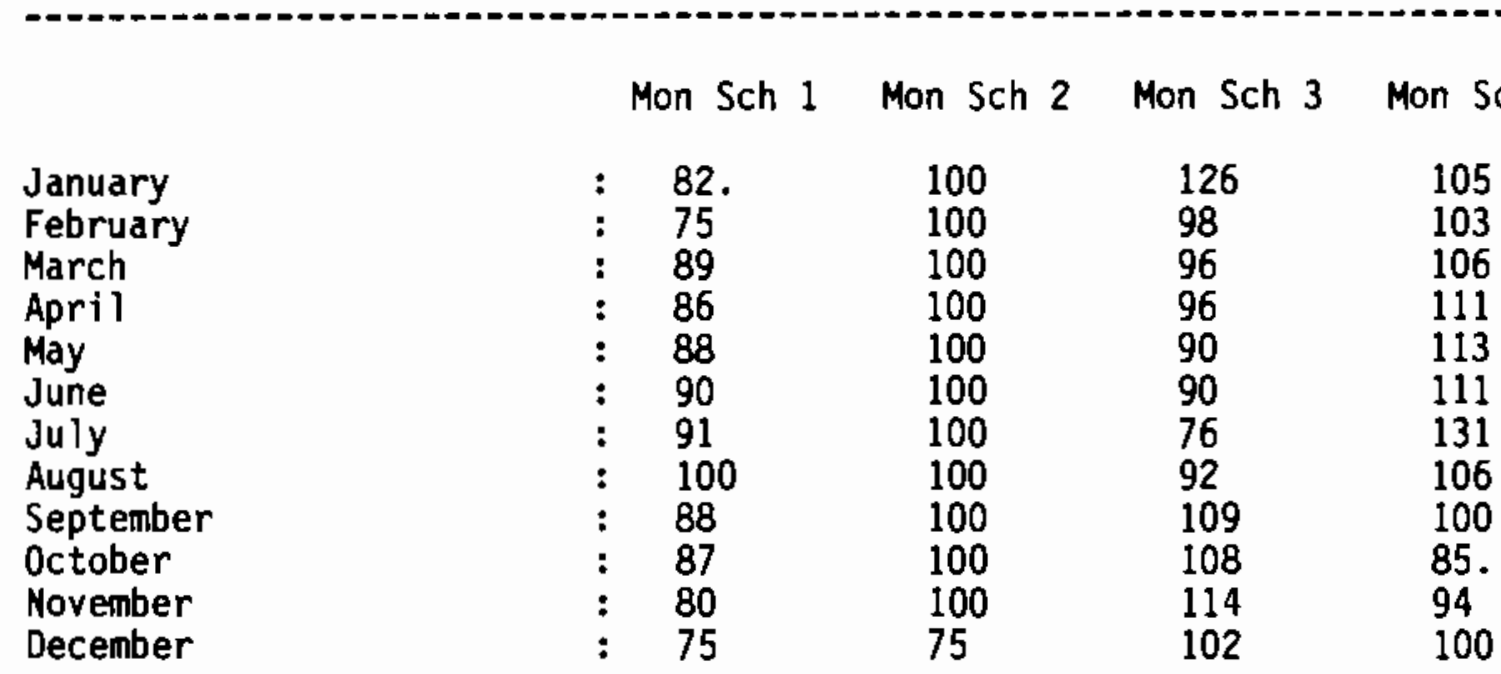


SYSTEMS INPUT TO ASEAM2

B. 28 
DATA ECHO FOR SYSTEMS INPUT FILE - REVBASDC.SID

SYSTEM TYPE - SINGLE ZONE REHEAT

SYSTEM LABEL - Single Zone Reheat for Zone 1

ZONES ASSIGNED TO SYSTEM 1 - Single Zone Reheat for Zone 1

Load Zone Zone Label

1 WEST DINING AREA

HEATING PARAMETERS FOR SYSTEM 1 - Single Zone Reheat for Zone 1

Heating plant type

Heating available below

Heating availability

Design heating discharge temperature
: District Heating

: $70 \operatorname{deg} \mathrm{F}$

: Jan through Dec

: $110 \operatorname{deg} \mathrm{F}$

COOLING PARAMETERS FOR SYSTEM 1 - Single Zone Reheat for Zone 1

Cooling plant type

Outside temperature below which cooling is off

Cooling availability

Design cooling coil discharge temperature
: District Cooling

: $55 \operatorname{deg} F$

: Jan through Dec

: $50 \operatorname{deg} \mathrm{F}$

PREHEAT PARAMETERS FOR SYSTEM 1 - Single Zone Reheat for Zone 1

Preheat plant type

: None

HUMIDIFICATION PARAMETERS FOR SYSTEM 1 - Single Zone Reheat for Zone 1

Humidification plant type

: None

BASEBOARD PARAMETERS FOR SYSTEM 1 - Single Zone Reheat for Zone 1

Baseboard plant type

: None 
FAN PARAMETERS FOR SYSTEM 1 - Single Zone Reheat for Zone 1

$\begin{array}{ll}\text { Total supply fan power required } & : \text { Defaulted } \\ \text { Supply fan temperature rise } & : 2 \mathrm{deg} \mathrm{F} \\ \text { Total return fan power required } & : 0 \mathrm{KW} \\ \text { Return fan temperature rise } & : 0 \mathrm{deg} F \\ \text { Unoccupied cycle fan control method } & : \text { On Continuous ly }\end{array}$

OUTSIDE AIR PARAMETERS FOR SYSTEM 1 - Single Zone Reheat for Zone 1

Occupied Cycle

Outside air damper control method Minimum percent outside air intake

: Fixed Dampers

Unoccupied Cycle

Outside air damper control method

Minimum percent outside air intake

$: 10 \%$

: Fixed Dampers

: $10 \%$

ZONE AIR PARAMETERS FOR SYSTEM 1 - Single Zone Reheat for Zone 1

Zonal air volume method

Percent of design default air flow
: Autosized

: $80 \%$ 
DATA ECHO FOR SYSTEMS INPUT FILE - REVBASDC.SID

SYSTEM TYPE - SINGLE ZONE REHEAT

SYSTEM LABEL - Single Zone Reheat for Zone 2

ZONES ASSIGNED TO SYSTEM 2 - Single Zone Reheat for Zone 2

$\begin{array}{cc}\text { Load Zone Zone Labe] } \\ 2 & \text { EAST DINING }\end{array}$

HEATING PARAMETERS FOR SYSTEM 2 - Single Zone Reheat for Zone 2

Heating plant type

Heating available below

Heating availability

Design heating discharge temperature
: District Heating

: $65 \operatorname{deg} \mathrm{F}$

: Jan through Dec

: $110 \operatorname{deg} F$

COOLING PARAMETERS FOR SYSTEM 2 - Single Zone Reheat for Zone 2

Cooling plant type

Outside temperature below which cooling is off Cooling availability

Design cooling coil discharge temperature
: District Cooling

: $55 \operatorname{deg} F$

: Jan through Dec

: $50 \operatorname{deg} \mathrm{F}$

PREHEAT PARAMETERS FOR SYSTEM 2 - Single Zone Reheat for Zone 2

Preheat plant type : None

HUMIDIFICATION PARAMETERS FOR SYSTEM 2 - Single Zone Reheat for Zone 2

Humidification plant type

: None

BASEBOARD PARAMETERS FOR SYSTEM 2 - Single Zone Reheat for Zone 2 
FAN PARAMETERS FOR SYSTEM 2 - Single Zone Reheat for Zone 2

Total supply fan power required Supply fan temperature rise Total return fan power required Return fan temperature rise Unoccupied cycle fan control method

: Defaulted

: $2 \operatorname{deg} F$

: $0 \mathrm{KW}$

: $0 \operatorname{deg} \mathbf{F}$

: On Continuously

OUTSIDE AIR PARAMETERS FOR SYSTEM 2 - Single Zone Reheat for Zone 2

Occupied Cycle

Outside air damper control method

Minimum percent outside air intake Unoccupied Cycle

Outside air damper control method

Minimum percent outside air intake

: Fixed Dampers

$: 10 \%$

: Fixed Dampers

$: 10 \%$

ZONE AIR PARAMETERS FOR SYSTEM 2 - Single Zone Reheat for Zone 2

Zonal air volume method

Percent of design default air flow
: Autosized

: $80 \%$ 
DATA ECHO FOR SYSTEMS INPUT FILE - REVBASDC.SID

SYSTEM TYPE - HEAT \& VENT UNIT

SYSTEM LABEL - Heat \& Vent Unit for Zones 3 and 7

ZONES ASSIGNED TO SYSTEM 3 - Heat \& Vent Unit for Zones 3 and 7

$\begin{array}{ll}\text { Load Zone } & \text { Zone Label } \\ 3 & \text { DISHWASHER } \\ 7 & \text { EMPLOYEE }\end{array}$

HEATING PARAMETERS FOR SYSTEM 3 - Heat \& Vent Unit for Zones 3 and 7

Heating plant type

Heating available below

Heating availability

Design heating discharge temperature
: District Heating

: 65 deg $\mathrm{F}$

: Jan through Dec

: $110 \operatorname{deg} \mathrm{F}$

PREHEAT PARAMETERS FOR SYSTEM 3 - Heat \& Vent Unit for Zones 3 and 7

Preheat plant type

: None

HUMIDIFICATION PARAMETERS FOR SYSTEM 3 - Heat \& Vent Unit for Zones 3 and 7

Humidification plant type

: None

BASEBOARD PARAMETERS FOR SYSTEM 3 - Heat \& Vent Unit for Zones 3 and 7

Baseboard plant type

: None

FAN PARAMETERS FOR SYSTEM 3 - Heat \& Vent Unit for Zones 3 and 7

Total supply fan power required Supply fan temperature rise Unoccupied cycle fan control method
$: 2.6 \mathrm{KW}$

: $2 \operatorname{deg} F$

: On Continuously 
ZONE AIR PARAMETERS FOR SYSTEM 3 - Heat \& Vent Unit for Zones 3 and 7

Zonal air volume method

Zonal fan power method

Percent of design default fan KW
: Entered by Zone

:

: \%

ZONE CFM PARAMETERS FOR SYSTEM 3 - Heat $\&$ Vent Unit for Zones 3 and 7

$\begin{array}{lll}\text { Loads } & \text { Zone Name } & \text { Zone } \\ \text { Zone } * & \text { or Label } & \text { CFM } \\ 3 & \text { DISHWASHER } & : 4840 \\ 7 & \text { EMPLOYEE } & : 660\end{array}$


DATA ECHO FOR SYSTEMS INPUT FILE - REVBASDC.SID

SYSTEM TYPE - CONSTANT VOLUME REHEAT

SYSTEM LABEL - Constant Volume Reheat for Zones 4,5,6

ZONES ASSIGNED TO SYSTEM 4 - Constant Volume Reheat for Zones 4,5,6

$\begin{array}{cl}\text { Load Zone } & \text { Zone Label } \\ 4 & \text { KITCHEN } \\ 5 & \text { STORAGE } \\ 6 & \text { OFFICE }\end{array}$

HEATING PARAMETERS FOR SYSTEM 4 - Constant Volume Reheat for Zones 4,5,6

Heating plant type

Heating available below

Heating availability

Design heating discharge temperature
: District Heating

: $65 \mathrm{deg} F$

: Jan through Dec

: $110 \operatorname{deg} \mathrm{F}$

COOLING PARAMETERS FOR SYSTEM 4 - Constant Volume Reheat for Zones $4,5,6$

Cooling plant type

Outside temperature below which cooling is off

Cooling availability

Design cooling coil discharge temperature

Discriminator control

Maximum cooling coil discharge temperature

: District Cooling

: 55 deg $F$

: Jan through Dec

: 50 deg $\mathrm{F}$

: Yes

: $60 \mathrm{deg} F$

PREHEAT PARAMETERS FOR SYSTEM 4 - Constant Volume Reheat for Zones $4,5,6$

Preheat plant type

: None

HUMIDIFICATION PARAMETERS FOR SYSTEM 4 - Constant Volume Reheat for Zones $4,5,6$

Humidification plant type

: None

BASEBOARD PARAMETERS FOR SYSTEM 4 - Constant Volume Reheat for Zones 4,5,6

Baseboard plant type

: None 
FAN PARAMETERS FOR SYSTEM 4 - Constant Volume Reheat for Zones 4,5,6

Total supply fan power required Supply fan temperature rise

$: 7.5 \mathrm{KH}$

Total return fan power required

: $2 \operatorname{deg} F$

Return fan temperature rise

Unoccupied cycle fan control method

$: 0 \mathrm{KW}$

: 0 deg F

: On Continuous Ty

OUTSIDE AIR PARAMETERS FOR SYSTEM 4 - Constant Volume Reheat for Zones 4,5,6

Occupied Cycle

Outside air damper control method Minimum percent outside air intake

: Fixed Dampers Unoccupied Cycle

Outside air damper control method

Minimum percent outside air intake

: $10 \%$

: Fixed Dampers

: $10 \%$

ZONE AIR PARAMETERS FOR SYSTEM 4 - Constant Volume Reheat for Zones 4,5,6

Zonal air volume method

: Entered by Zone

ZONE CFM PARAMETERS FOR SYSTEM 4 - Constant Volume Reheat for Zones 4,5,6

$\begin{array}{ccc}\text { Loads } & \text { Zone Name } & \text { Zone } \\ \text { Or Label } & \text { CFM } \\ 4 & \text { KITCHEN } & : 1321 \\ 5 & \text { STORAGE } & : 567.3 \\ 6 & \text { OFFICE } & : 240\end{array}$


PLANT INPUT TO ASEAM 2

B. 37 
DATA ECHO FOR PLANT INPUT FILE: REVBASDC.PID

ENERGY COSTS/CONVERSIONS

\begin{tabular}{|c|c|c|c|c|}
\hline Fuel Type & $\begin{array}{l}\text { Energy } \\
\text { Units }\end{array}$ & $\begin{array}{l}\text { Unit } \\
\text { Cost }\end{array}$ & $\begin{array}{c}\text { Conversion } \\
\text { site }\end{array}$ & $\begin{array}{c}\text { Factors (BTU/Unit) } \\
\text { Source }\end{array}$ \\
\hline $\begin{array}{l}\text { Electricity } \\
\text { Natural Gas } \\
\# 20 i 1 \\
\$ 40 i 1 \\
\# 60 i 1 \\
\text { Dist Heating } \\
\text { Dist Cooling }\end{array}$ & $\begin{array}{l}\text { KWH } \\
\text { Therms } \\
\text { Gallons } \\
\text { Gallons } \\
\text { Gallons } \\
\text { MBTU } \\
\text { MBTU }\end{array}$ & $\begin{array}{l}\$ 0.0 \\
\$ 0.0 \\
\$ 0.0 \\
\$ 0.1 \\
\$ 0.8 \\
\$ 9 . \\
\$ 9.1\end{array}$ & $\begin{array}{r}3,413 \\
100,000 \\
138,700 \\
141,000 \\
149,700 \\
1,000,000 \\
1,000,000\end{array}$ & $\begin{array}{r}11,600 \\
100,000 \\
138,700 \\
141,000 \\
149,700 \\
1,390,000 \\
1,000,000\end{array}$ \\
\hline
\end{tabular}

MISCELLANEOUS ENERGY CONSUMPTION

DOMESTIC HOT HATER

Domestic Hot Water Energy Source

Domestic\$ot Water Heating Capacity

Peak hourly DHW usage

Average hourly DHW usage - occupied cycle Average hourly DHW usage - unoccupied cycle

DHW Temperatures

Domestic how water supply temperature

DHW inlet temperature - design summer

DHW inlet temperature - design winter

Circulating Pumps

Circulating pump KW - occupied cycle

Circulating pump KW - unoccupied cycle

Domestic Hot Water Efficiency and Losses

Design DHW heating efficiency

DHW losses - occupied cycle

DHW losses - unoccupied cycle
: District

: Autosized

: gal/hour

: $10 \mathrm{gal} / \mathrm{hour}$

: $1 \mathrm{gal} /$ hour

: $130 \operatorname{deg} \mathrm{F}$

: $55 \mathrm{deg} F$

: $45 \operatorname{deg} \mathrm{F}$

: $0 \mathrm{KW}$

$: 0 \mathrm{KW}$

: $85 \%$

: 50 BTUH

: 50 BTUH 
PNL-6610

UC-95d

DISTRIBUTION

No. of

Copies

OFFSITE

25 Thomas Ove

HQ AFESC/DEHRD

Tyndall AFB, Florida 32403-6001

2 DOE Technical Information

Center

\section{ONSITE}

DOE Richland Operations Office

E. C. Norman/D. R. Segna

22 Pacific Northwest Laboratory

S. A. Bailey

R. P. Mazzucchi (10)

T. J. Secrest (5)

P. W. Zimmerman

Publishing Coordination (2)

Technical Report Files (3) 
